SERVIÇO DE PÓS-GRADUAÇÃO DO ICMC-USP

Data de Depósito: $\quad$ 17.04.2001

Assinatura:

\title{
Estudos em Transmissões Multicasting de Vídeo Comprimido
}

\author{
Leonardo Antonio de Andrade
}

Orientador: Prof. Dr. Edson dos Santos Moreira

Dissertação apresentada ao Instituto de Ciências Matemáticas e de Computação - ICMC-USP, como parte dos requisitos para obtenção do título de Mestre em Ciências de Computação e Matemática Computacional.

USP - São Carlos

Abril/2001 


\section{A Comissão Julgadora:}

Prof. Dr. Edson dos Santos Moreira

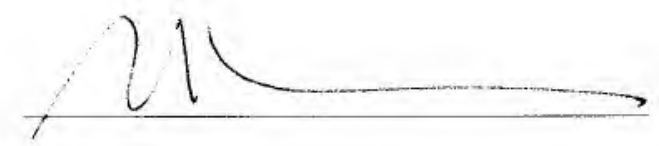

Profa. Dra. Tereza ('ristina Melo de Brito Carvalho

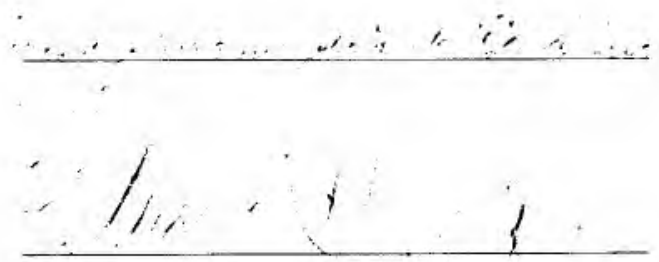

Prof. Dr. Eduardo Marques 
Este trabalho é dedicado à minha mãe. Anna Rodrigues de Andrade, e a todos que contribuiram para a sua conclusão. 


\section{Agradecimentos}

1 Deus, por permitir estar entre familiares e amigos c por me conceder força e coragem nos momenros cm que preciso.

I minha màc, Anna Rodrigues de Andrade, por todo o csforço dedicado à minha formaçào como pessoa c pesquisador. Muito obrigado Mama!

Io oricntador, Prof. Dr. Lidson dos Santos Moreira, que sempre acreditou em mim, me auxiliando c direcionando nos momentos de dúvidas, e por todas as oportunidades proporcionadas.

Io men anigo Luciano Martins, companheiro de cstudos e trabalho, com o qual dividi muitas madrugadas programando e realizando testes no laboratórios InterMidia. Valeu I Iombre!

Ios meus amigos Gustavo, João, Rudinei e Walter, c a todos do laboratório InterMídia pelos incentivos, idéias e conhecimentos compartilhados, pelas correçòes da qualificaçào e dissertaçào, e principalmente pelo companheirismo em todos os momentos.

1 todes os docentes que me proporcionaram conhecimentos fundamentais em suas disciplinas durante o mestrado, e que contribuíram para o desenvolvimento destc trabalho.

I todes os amigos e amigas que me ajudaram a terminar este trabalho. 
1 implementaçào de uma aplicaçào cliente/servidor de vídeo apresenta aspectos complexos e que exigem tratamento diferenciado, como trabalhar com arquivos que ocupam grande espaço de armazctamento e fluxos de dados que necessitam de alta largura de banda para serem transmutidos. Quando o fluxo de dados é compactado e a transmissào é fcita com técnicas de Imulturuting a transmissào se torna ainda mais complexa. Um excmplo típico é a utilizaçào de pacoles L'D P', que podem ser perdidos e/ou chegarem ao destino desordenados, durante uma sessăo de transmissào c recepção. Nesta dissertação são discutidas as implementaçòes de duas aplicacries clicnte/servidor que cxploram as técnicas de multicasting (uma delas possuindo suporte para Il'v+ e R'IP, c a outra suporte para IPv4 ou IPv6). A problemática do envio e recebimento de pacotes para posterior exibiçào do vídeo pelo cliente foi estudada c alguns testes foram feitos com us padròcs de compressào MJPJG e um método proposto, implementado com transtormadas yanelets e codificação I.ZW.W. Medidas c comparações de descmpenho foram realizadas, utilizando-se os sistemas operacionais Jinux e Windows. As conclusòes obtidas com a metodologia aplicada a este trabalho podem contribuir para a solução da problemática da transuntssáo de vídeo em ambientes multicusting, especialmente para o caso de extensòes e refinamentos nas implementaçoes realizadas e no desenvolvimento de aplicaçòes que incluam coutros componentes de hardware e softwarc. 
The implementation of a client/server video application has many complex aspects which need special attention. Dealing with files that need large space of storage and data streams that need large bandwidth to be transmitted are some of them. When data streams are compressed and the transmission is done through multicasting techniques, the transmission becomes much morc complex. A classical example is when these streams are encapsulated into UDP packages, that can be lost and/or arrive out of order at the destination. The syncronization of the presentation is difficult. This dissertation describes two client/server implementations that explore multicasting techniques (one of them having IPv4 and RTP support, and other with IPv4/IPv6 support). The problem of sending and receiving packets to future video exhibition by client was studied and many tests were made with MJPEG compression and other technique, implemented with walcket transforms and LZW codification. Measures and performance were compared, using two operational systems, Linux and Windows, and the results were showed in tables and graphics. The experience and results achieved with the applied methodology can contribute to solve some problems of video transmission in a multicasting environment. Directions for extending and refining the systems implemented in this project and in the development of applications that include other hardware and software components are given. 


\section{Sumário}

1 - Introduçăo

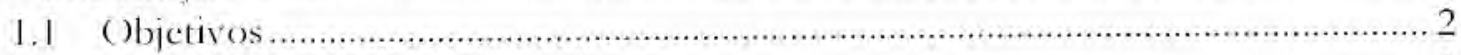

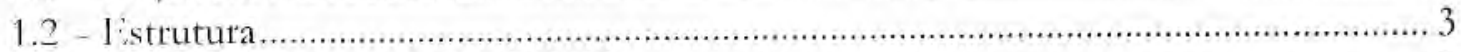

2 - T'écnicas de Compressão de Vídco .................................................................

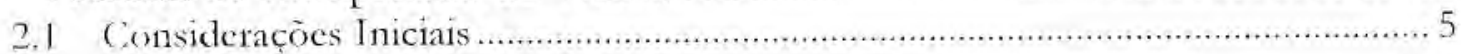

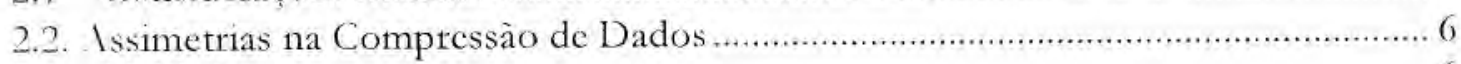

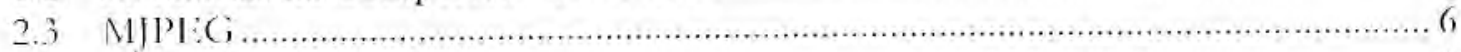

2.4 MPIG 2 .

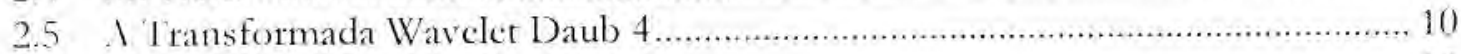

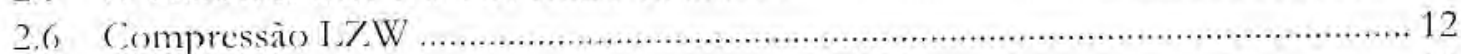

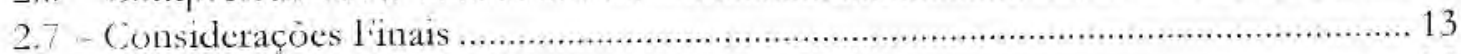

3 - Protocolos e Técnicas de T'ransmissào de Dados .................................................. 15

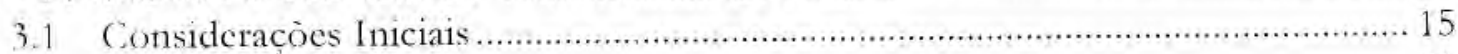

$3.2 \quad I P v 6 \ldots$

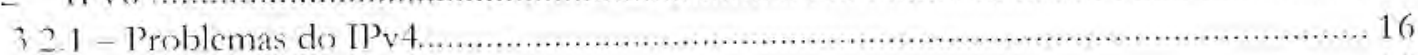

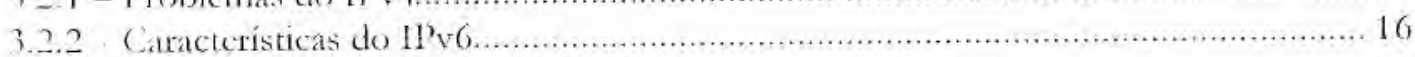

3.2 .3 - Representação do Fndercço IPv6 _.............................................................. 18

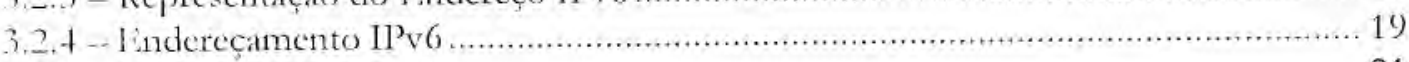

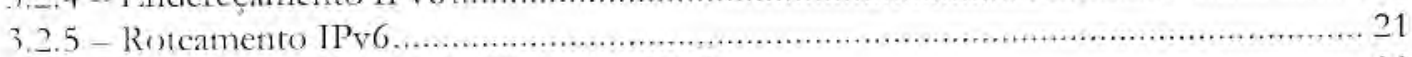

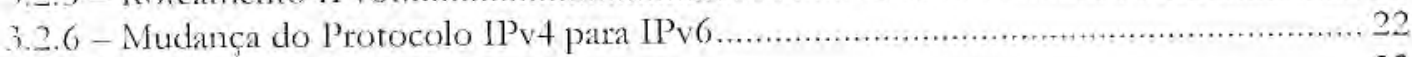

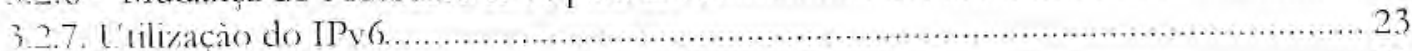

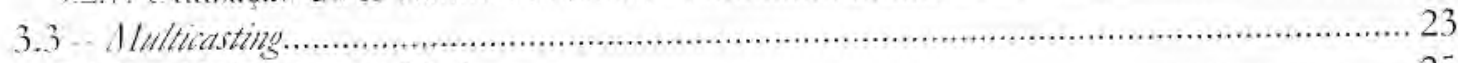

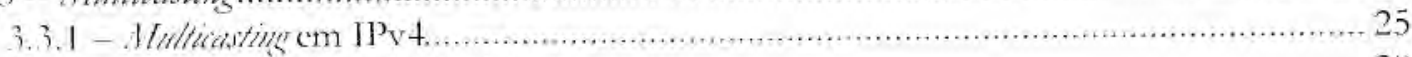

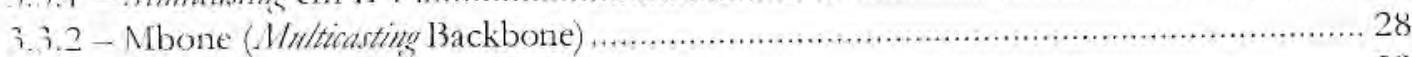

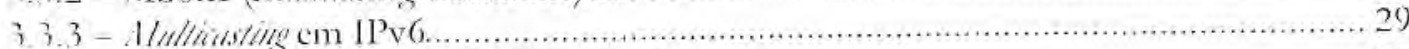

3.4-Protocolo RTP (Real-Time Transport Protoco) ......................................................31

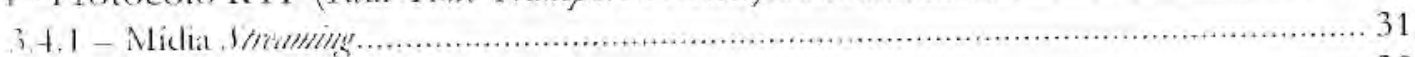

3. +.2 - Protocolos para Mídia Streaming..........................................................................32

34.3 - Servicos R'P

3.5 - Consideraçòes Finais ................................................................................ 34

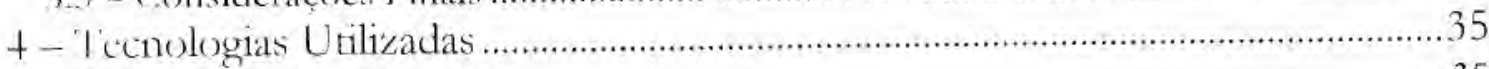

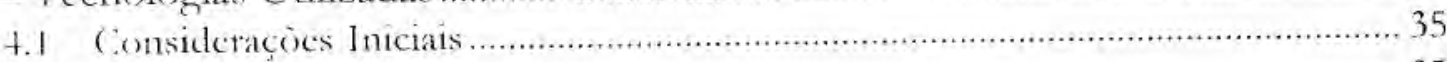

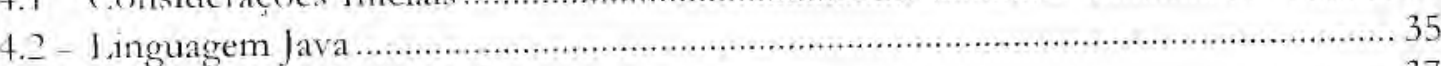

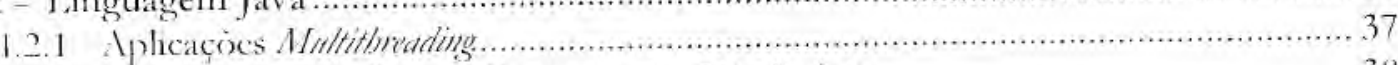

t.2.2 - Aplicaçòes Baseadas em Comunicaçào Via Sockets....................................................38

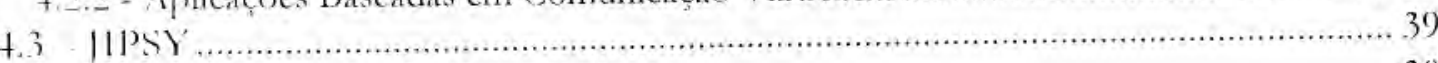

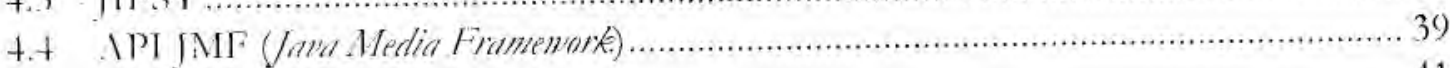

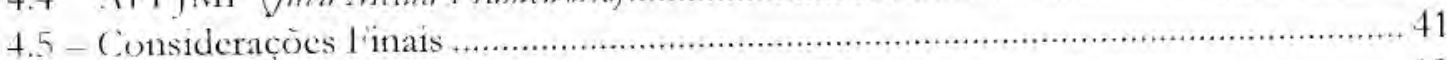

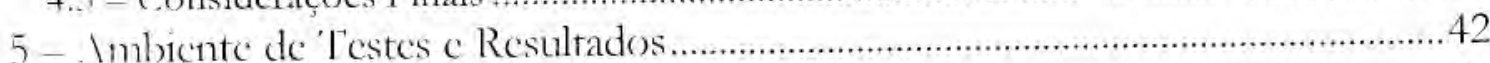

5.1 - Consideraçòes Iniciais .................................................................................. 42 


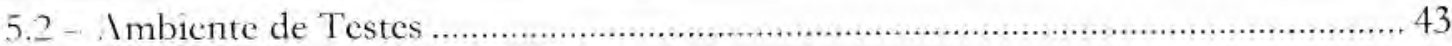

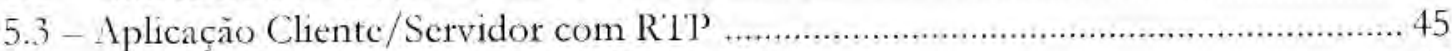

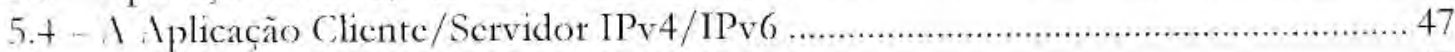

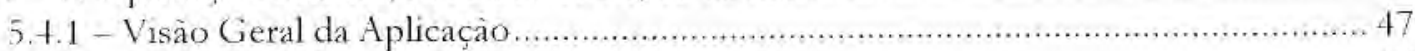

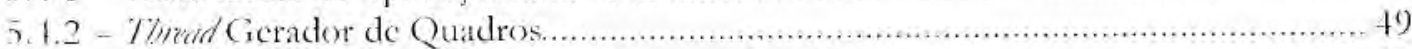

5 4.3 - Problemáticas no Envio e Recebimento dos Datagramas, ........................................ 50

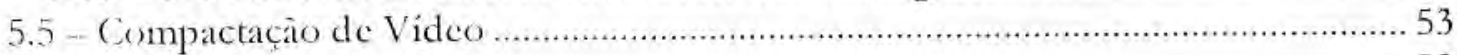

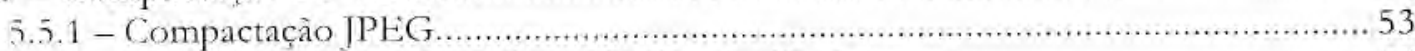

5.5.2 - Implementaçà da I'ransformada Wavelet Daub4 _............................................... 56

5.5.3 - Medidas de Tempo da Daub4 em Imagens em Escalas de Cinza e Coloridas ......... 59

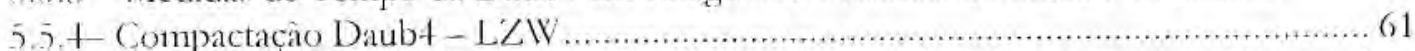

5.5.5-1)escmpenho da Descompactaçào JPFG e Daub4-J.7WW nas Máquinas Virtuais Java

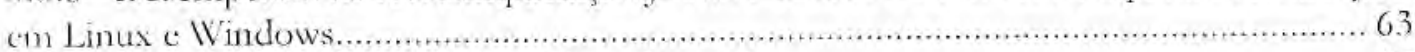

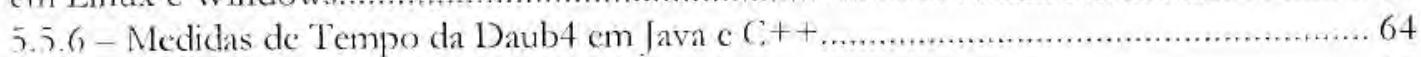

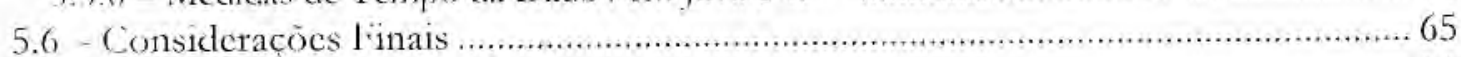

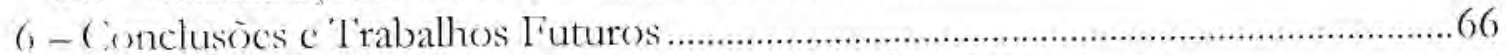

6.1 - Análise dos Resultados Obtidos e Propostas Para Trabalhos Futuros....................67

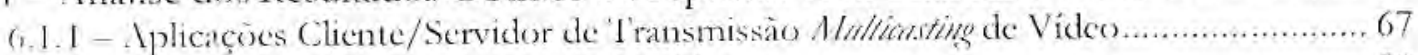

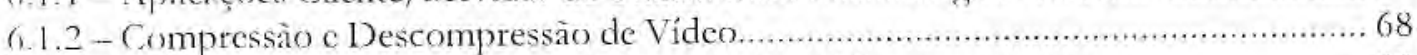

6.2 - Contribuiçoes em Trabalhos do Grupo Inter Midia ............................................69 69

6. 2.1 - Iransmissào de Vídeo Usando IPvG e Multicasting em Redes de Alto Desempenho

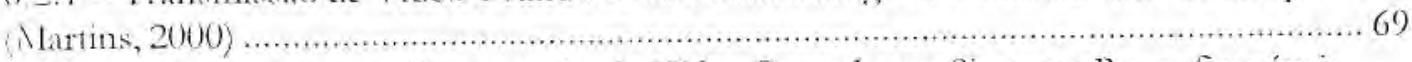

6,22 - Arquiteturas para Compressào de Vídoo Baseado em Sistemas Reconfiguráveis

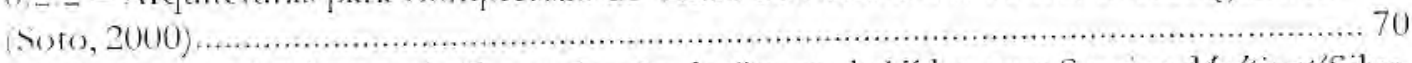

6.2.3-Projeto de Sistema de Sincronização de. Stzrauss de Vídeo para Serviço Multicast (Silva,

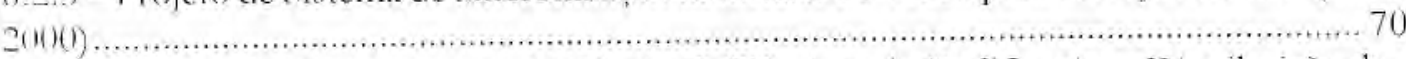

6.2.4 - Sobre a Implementação e Avaliaçào de lécnicas de Codificaçào e Distribuição de

$\checkmark$ ideo Baseadas em Conteúdo (Goulart, 2000) …..................................................... 70

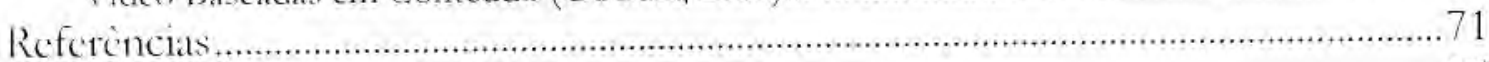

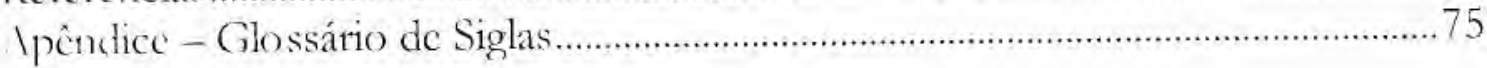




\section{Lista de Figuras}

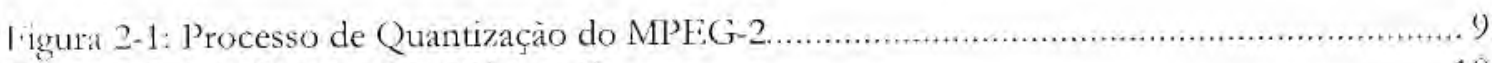

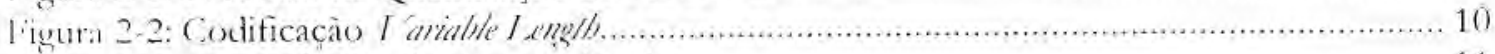

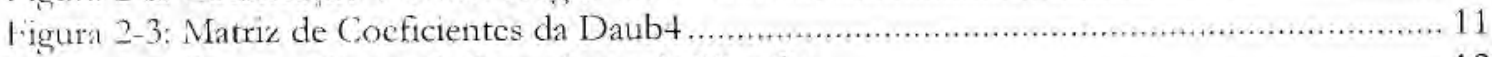

ligura 2-4: Primeiro Passo da 'l'ransformada Wavelet ................................................ 12

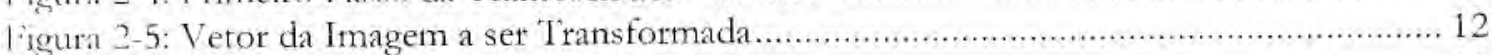

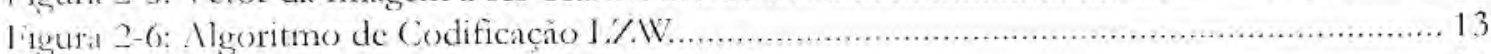

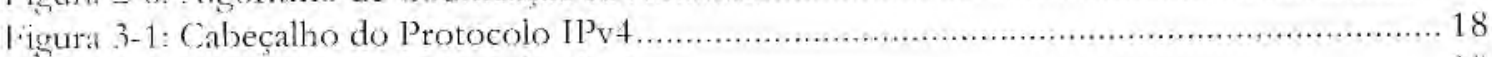

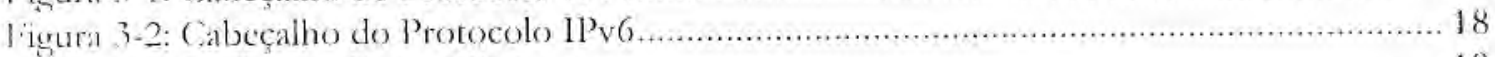

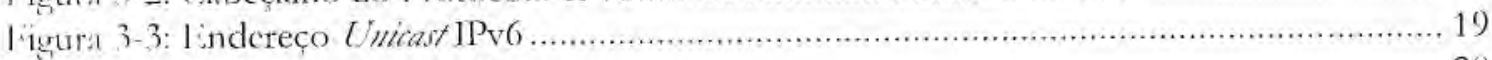

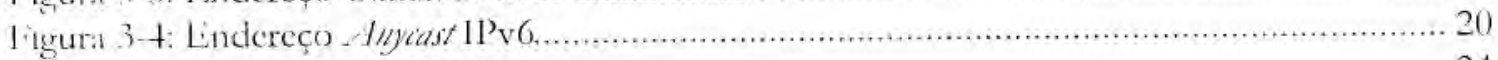

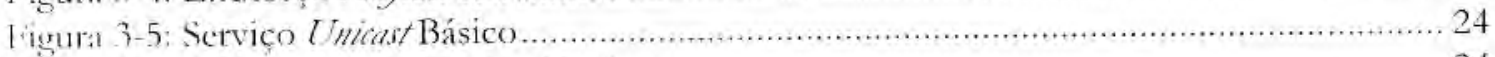

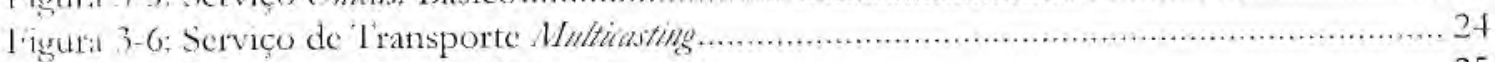

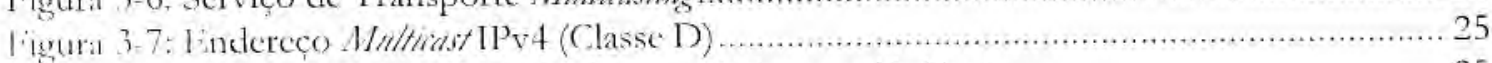

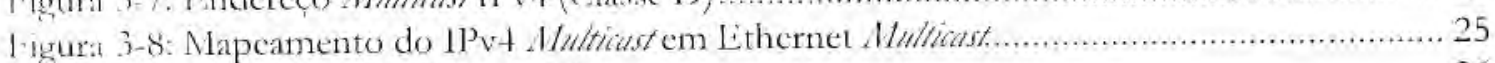

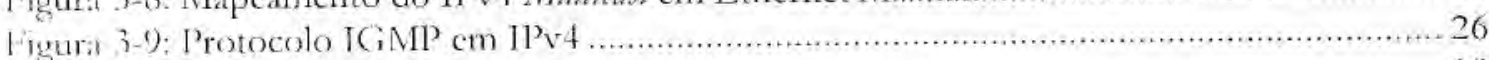

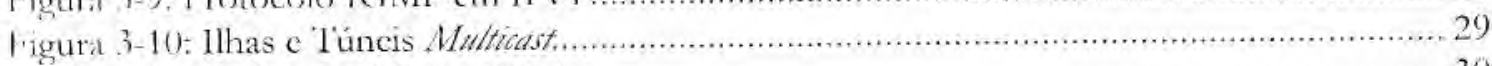

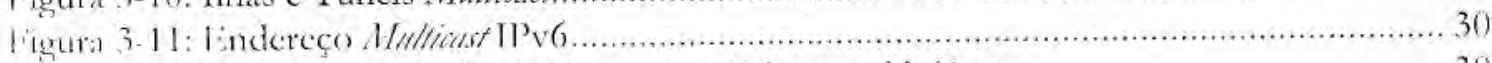

1.igura 3-12 Mapeamento do IPvG Multicast cm Ethernet Multiast....+.................................. 30

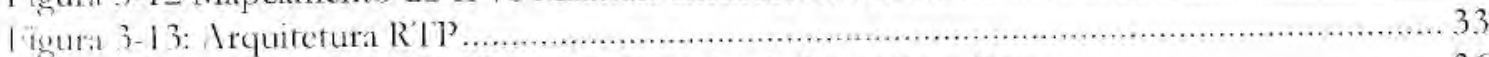

Iigura t-1: Fisquema de Compilaçào c Fxecuçào de Programas Java ..................................36

ligura +2: lisquema da Comunicaçào Clicnte /Servidor via dockéts.................................... 38

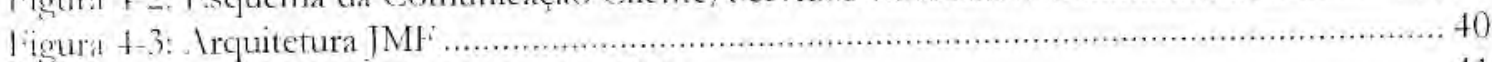

liguri $f$ t: Listados de um Processador JMt .......................................................... 41

ligura ;-1: lisquema do Ambiente de Descnvolvimento .............................................. 43

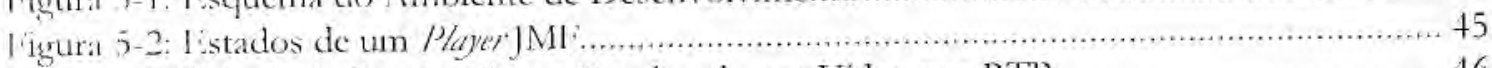

ligura 5-3: 'T da da Aplicaçào Cliente Recebendo um Vídeo por RTP ..................................46

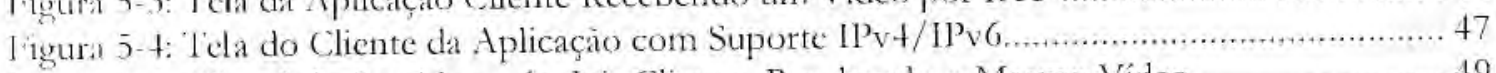

1.igura 5-5: Thersts do Servidor c de dois Clientes Recebendo o Mesmo Vídeo......................... 49

ligura 5-6: Representaça em bits de um int da Liguaguem Java.......................................... 50

ligura 5-7: () uadros Remontados com Pacotes [11)] …............................................... 51

Figura 5-8: (iráfico do l'amanho do trquivo em Relaça ao l'empo de Descompressão ......... 5t

liggra 5-9): Cirifico de lamanbo do Arquive Descomprimido em Relaçào as Arquivo

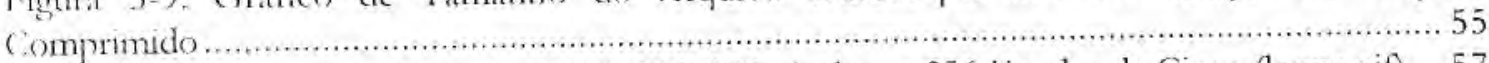

l'igura 5-10: Imagem de Teste do IFISE, 256x256 pixels em 256 liscalas de Cinza (lenna.gif).... 57

Jigura 5-11: Imagem Obtida na l'ransformaçào wavelet, com 91,79\% de Compressảo Relativa e

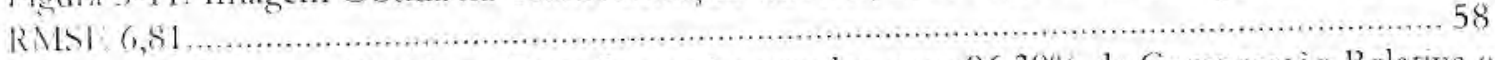

1'19ura 5-12: Imagem Obrida na T'ransformacào wavelet, com 96,39\% de Compressào Relativa c

RMSI 10,76 ............................................................................................................. 61

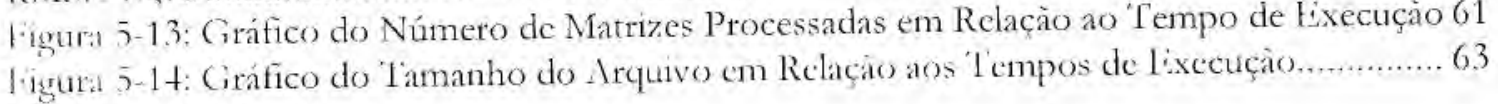




\section{Lista de Tabelas}

Labcla 5-1: Dados da Compactação JPLG com codificadores da Sun Microsystem........................ 54

Tabctia 52: Valores Obtidos no Processamento da Imagem (lenna.gif) ....................................58

labela 5-3: Cocficientes da Daub4 represcntados cm Ponto Flutuante e Intciros......................59

Tabela 5-t: Medidas de T'empo da Daub4 para Imagens em 1zscalas de Cinza c Coloridas......... 61

l'abeliı 5-5: Dados da Descompactaçào com a Transformada Wavelet e Codificaçào LZW.......62

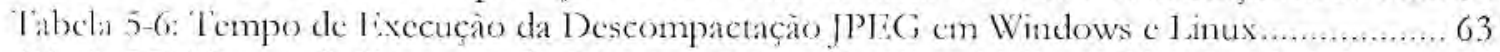

labelis 5-7: 'Tempo de Execução da Descompactação Daub4 - LZW no Windows NT 4.0...... 64

labela 5-8: "Tempo de Lxecuçào da Descompactaçào Daubt - LZWW no Linux Red I Jat 6.2 .... 64

labcla 5-9: T'empo de Execução de uma 'Transformada Wavelet Daub4 cm Sistemas

()peracionats Diferentes.

64 


\section{Capitulo}

\section{Introdução}

() aumento na largura de banda (bandwidto) e a diversidade de recursos das novas tecnologias de redes de comunicaçào podem impulsionar o surgimento de novos paradigmas e novas aplicaçòes. Vesse cenário, as aplicações multimídia, especialmente as transmissòes de vídeo, tendem a ocupat uma prsiçào de destaque. Para distriburr vídeo, é necessário uma máquina conectada a uma rede de comunicaçào c que execute uma aplicaçào scrvidora. lím adiçào, uma boa capacidade de banda passante é necessária, pois mesmo considerando as novas tecnologias, se a qualidade exigidir para o vídeo for alta, a transmissăo pode causar congestionamento no tráfego da rede. Vém da qualidade do vídeo, o protocolo c a técnica de transmissào utilizados também podem determinar a eficiência da transmissào que cstiver sendo realizada.

Trualnente, o protocolo de comunicaço mais difundido em redes de computadores é o IPv4

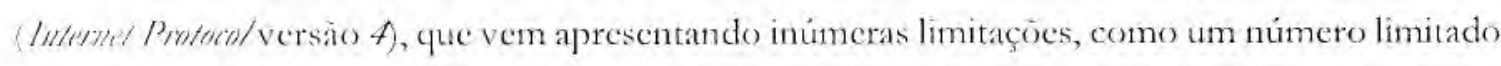
de endereços e a ausência de prioridade para a transmissào de dados diferentes. A soluçào encontrada c a substituiçào do protocolo IPv4 para sua nova versão, o IPv6 (Internet Protocol versào a), que fornece um número muito maior de endereços c prové esquemas de prioridade, de acorde eom on lipo de dado a ser transmitido. Além disso, o IPvG possui cabeçalhos simplificados, facilitatio o processamento nos roteadores (Decring, 1995). Devido às suas características, o IPvo rem potencial para melhorar a qualidade de serviço (QoS - Qunality of Serrice) de aplicaçòcs que distribuam video, por exemplo.

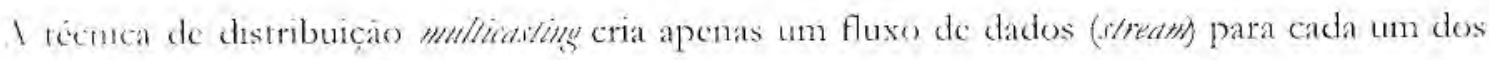
Clentes, sender sua inclusăo necessária na implementaçà de um servidor de vídeo para comemizar a largura de banda da rede. $\Lambda$ implementaçào da técnica de multicasting no protocolo

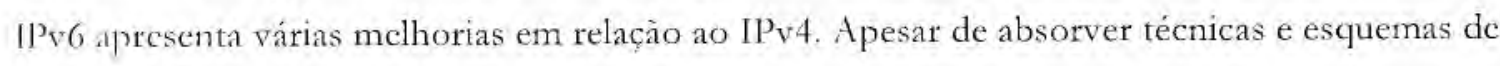


seu antecessor, o IPv6 adiciona mudanças significativas em relaçăo ao endereçamento $e$ roteancute.

Outro modo de diminuir a largura de banda é bascado nas técnicas de compressào de dados (1/uckiger, 1995; Stcinmetz, 1995). Alguns padròes de compressào já se encontram bastante difundidos, como JPEG (Joint Picture Expent Group) (Thakrar, 1996) e MPEG-2 (Motion Picture Lixpent Group) (ISO, 1997), e como esta é uma área em constante descnvolvimento, novos padrocs tèm surgindo, com vistas a apresentar sempre maior ganho cm eficiência. Um dos passos ta implementaçấo de um padrào de compressảo, é a aplicaçào de uma transformada discreta nos dades de um ou mais quadros de um video. Uma nova transformada, chamada mavelel, vem substituindo as tradicionais transformadas de coscnos, por possuir menor complexidade para implementaça e maior eficiência de processamento. Neste trabalho, medidas de tempo de compressio de imagens foram efetuadas utilizando-se dos recursos do padrào JPIG e um novo padrà propesto, utilizando transformadas marelets c a codificaçăo JZWW (Lempel, Ziv e Welch).

\section{1 - Objetivos}

()s objetivos deste trabalho estào inseridos no contexto da problemática da transmissao de vídeo en unal aplicaçao clicnte/servidor com suportc a multriating através dos recursos dos protocolos IPvt a IPv6. A tomada de medidas de tempo de compressão de quadros de vídeo individuais, utilizando o padrào JPEG e um método que utiliza transformadas maveletr c a codificaçào LZW, sào aspectos particularmente relevantes e fazem parte dos objetivos especificos deste trabalho.

Como suporte aos objetivos definidos, for realizada a configuraça de um ambiente com suporte

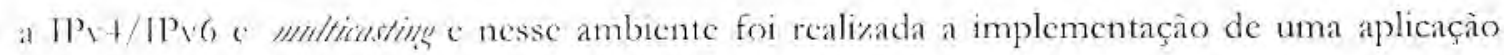
cliente/scrvidor, utilizando tecnologias de domínio público, tais como o sistema operacional linux e a linguagem Java, da Sun Microsystems. Algumas simplificaçòes foram feitas na implementaçào dessa aplicaçào, tais como:

- Pré-Processamento para posterior transmissão: inicialmente $\dot{c}$ detcrminado 0 tamanho de cada datagrama a ser enviado e, cntão, é gerado um arquivo cm formato proprictário; com essa simplificaçào, o tempo nccessário para a divisào de um quadro em varios pacotes fol reduzido; 
- Compactação intra-quadro: a compactaçào for feita internamente aos quadros, que foram tratados como imagens estáticas; a compactação inter-quadros é mais eficiente se comparada às compactaçoos intra-quadros; no entanto, se essa técnica de maior cficiência fosse utilizada, acarretaria uma complexidade muito maior na implementação da aplicaçào clicnte para processar a descompressào, considerando que pacotes UDP (User Datagram Pratocal podem chegar ao cliente fora de ordem ou até mesmo não chegar ao seu destino.

Cimo métrica, sảo apresentados cálculos para que a exibiçào do vídeo possa ser efutuada em tempo de geraçào. Sào também apreșentados testes, medidas c comparaçòes com alguns tipos de compressào (JPEG c mavelets em conjunto com I.ZNV), que poderào ser utilizados em trabalhos futuros para à construçào de aplicaçòes cliente/servidor mais complexas e elaboradas.

\section{2 - Estrutura}

lista disscrtaçào está organizada de forma a apresentar o contexto teórico no qual este trabalho está inserido, bem como os resultados obtidos no desenvolvimento do trabalho $\mathrm{c}$ as suas contibuicoes para a comunidade interessada:

- Capítulo 2: apresenta algumas técnicas difundidas de compressăo de vídeo como MIPT.G c MPEG-2, além de um tipo especial de transformada, que $\mathrm{cm}$ um conjunto com técnicas de compressào sem perda, também pode ser utilizada para compactar quadros individuais;

- Capítulo 3: apresenta o protocolo IPvG, especialmente suas características, funcionamento e detalhes de sua configuraçào cm alguns sistemas operacionais, a técnica de minticasting $\mathrm{e}$ seu funcionamento nos protocolos IPv4, IPv6 e Mbone, e o protocolo RTP (Real-ï̈me Tiansport Protocoł), utilizado para transmissào de dados que requerem cxibiçào em tempo real (como è o caso de áudio e sídeo); 
- Capítulo 4: apresenta as tecnologias usadas no trabalho, como a linguagem Java e seus recursos de programaçào com threads e sockets, o pacotc Jipsy-que permite trabalhar com

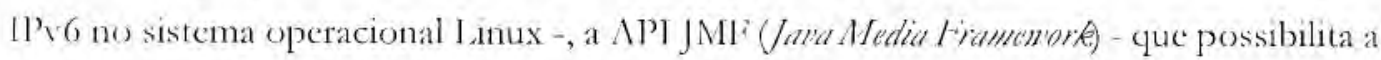
manipulaçào de vários arquivos de áudio e vídeo;

- Capítulo 5: mostra o ambiente de testes, as aplicaçòes descnvolvidas (para transmissão e para compressào de vídeo) e os resultados obtidos, devidamente documentados;

- Capítulo 6: apresenta as conclusoes deste trabalho, considerando as dificuldades e contribuiçòes, bem como algumas idéias para a extensào em trabalhos futuros. 


\section{Técnicas de Compressão de Vídeo}

\section{1 - Considerações Iniciais}

Tradicinalmente, os dados em um sistema multimidia, devido à sua natureza rica cm recursos ufue represcutam abstraçóes do "mundo teal", como é u caso do áudio e do vídeo, possucm earacıcristicas que tornam seu armazcnamento e disponibilização difícels, pois exigem, na maioria das veces, grandes quantidades de bytes de espaço para armazenamento, e uma alta largura de bandat para transmissào. Neste sentido, o uso de algoritmos e técnicas de compressão c descompressâr torna-se imprescindível para a viabilizaça do transporte de multimídia digital, tanto tue que dì respeito à comunicaçào quanto ao armazenamento dos dados.

Para a compressão e descompressào de video, diversos padrões já foram definidos, tais como 11261, 11263, MPEG-2, MPEG-4, Quicktime, dentre outros. Em relaçào à compactaçào de quadros, pode-se considerar a seguinte classificaçào:

- Intraquadro: os quadros sào comprimidos de forma independente, tal como uma secuiuencta de imagens cstáticas;

- Interquadro: o vídeo é comprimido obscrvando as semelhanças entre quadros consecutivos.

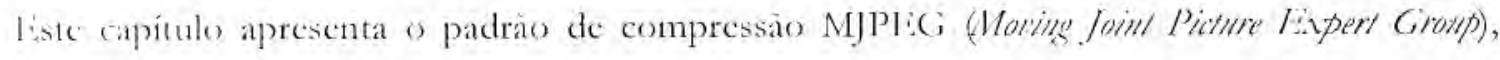
uilizacto tanto para imagens estáticas quanto para vídeo (intraquadro), e o padrão de compressão MPF: $i-2$, que oferece compressão interquadros e intraquadros. 
llém dos padrões definidos, é apresentada um nova técnica de compressão, na qual são utilizadas as transtormadas mavelets e a codificaçào LZW, que pode scr utilizada para compactar imagens estáticas ou video (intraquadro). As transformadas yaveletes vêm scndo alvo de estudos atuais para a determinaçào de novos padròes de compressào, como ćo caso do padrào JPLEG 2000.

\subsection{Assimetrias na Compressão de Dados}

() algeritmos de compressào e descompressào de dados são chamados de algoritmos de codificação c de decodificação, respectivamente, c apresentam algumas assimetrias televantes:

1. Para muitas aplicaçòes, um arquivo ou stream só será codificado uma vez (ao ser : mmaznado em um servidor multimidia), mas será decodificado inúmeras ve\%es (quando for visualizado pelos usuários). Jissa assimetria permite, portanto, que o algoritmo de codificacào seja lento e necessite de componentes de hardware de alto custo, desde que o algotitmo de decodificação seja rápido e nào precise de hardware muito caro.

2. Lima scgunda assimetria é que os processos de codificaçào e decodificaçào não precisam ser reciprocos. I im uma compactaçăo ideal, um usuário espera ter de volta o arquivo oriumal, exatamente como cra antes, porém um certo nível de perda é accitável em alguns casos (como em vídco, por excmplo).

Im sinal de video pode ser ligeiramente diferente do original depois da codificação e da posterior decollılicaça; neste caso, o sistema é dito com perda (hosin). Se a entrada ca sáda săo identicas,

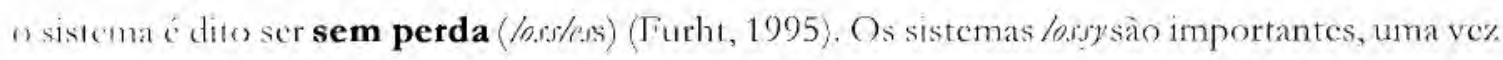
yue aceitar a perda de um pequeno volume de informaçòes pode oferccer uma grande vantagem em termos da taxa de compactaçăo possivel.

\section{3 - MJPEG}

JPI: C ¿ um padrão de compressão para imagens estáticas coloridas e branco-e-preto (imagens com tom contínuo) (l'hakrar, 1996). Além de imagens estáticas, esse padrào pode ser aplicado prara compressáo de vídeo intraquadros, tratando o vídeo como una sequência de imagens, recelondo o nome de MJPLG. 
I lí muitos paràmetros para o processo de compressão JPEG. Pelo ajuste desses parâmetros, prode se obter imagens com grande compressào em detrimento de uma boa qualidade, e viceversa. Por exemplo, pode-se obter uma compressàe 100:1 de uma imagem original de 24 bits, perdendo muita qualidade, ou uma compressão $3: 1$, com perda indistinguível.

Geralmente, utiliza-se uma compressão de 10:1 a 20:1 (Wallace, 1991). O padrào JPLG é baseado (nn um algoritmo com perda (105\%), além de extensòes opcionais para codificaçào progressiva e hierárquica. lixiste também um modo de compressão sem perda, que gera, tipicamente, uma compressào $2: 1$.

() padrào JPEG foi dividido em duas partes. $\Lambda$ parte 1 especifica os modos de operaçào, os formats e e o codificador especificado para esses modos. A parte 2 do padrào descreve os testes que deverminam se a implementaçào do codificador ou decodificador está em conformidade com 6 padrio, para garantir interoperabilidade de sistemas. O esboço do algoritmo de compressào IPFici c descrito a seguir (Wallace, 1991), sendo que o algoritmo de descompressào realiza o processo inverso:

1. I'ransformar a imagem dentro de uma faixa de cor adequada (caso scja colorida), ureralmente da codificaçào RGB para a codificação YCbCr ou YUV, o que permite uma perda de informaçáo nos componentes de crominância c luminância a que o olho humano nào é sensivel;

2. (Opcional) liransformar cada componente pela mediana de grupos de paxek, sendo o componente de luminância deixado $\mathrm{cm}$ resoluçào completa, enquanto componentes de crominância reduzidos em uma razào de 2:1 horizontalmente e 2:1 ou L:1 verticalmente, reduzindo o volume de dados pela metade ou em um terço, o que, em icrmos numéricos, é altamente losjy, mas para a maioria das imagens isto nào gera grande impacto na qualidade;

3. Agrupar valores de pixels para cada componente dentro de blocos $8 \times 8$, sendo cada bloco submetido a uma transformada de cosenos discretos (DCT), que é um tipo de transformada de Fourier, gerando um mapa de freqüencias com componentes $8 \times 8$, 
podendo-se descartar informaçòes de alta-freqüência sem afetar informações de baixa frequicincia;

4. Lim cada bloco, dividir os 64 componentes de frequêtncia por um "coeficiente de yuantizaçào" c arredondar os resultados em funçào de números inteiros, fundamental para descarte de dados;

5. Codificar os cocficientes reduzidos usando codificaçăo de l luffman ou arimética, nàc) afetando a qualidade da imagem (lows/ess);

6. Adicionar beaders com dados da compactação e gerar o arquivo final.

\section{4 - MPEG2}

Descle do inicio dos anos 80, o grupo MPEG (Motion Picture Expert Group) tem trabalhado na padronkaçăo de compactaçào de áudió e vídeo, tendo como resultado dois padròes, conhecidos como MPL:G-1 (IS-11172) c MPLG-2 (IS-13818). O primeiro cspecifica a codificaçào de áudio e rideo a laxas de $1,5 \mathrm{Mbps}$, e o segundo manipula a codificaçào genérica de TV digital e sinais de

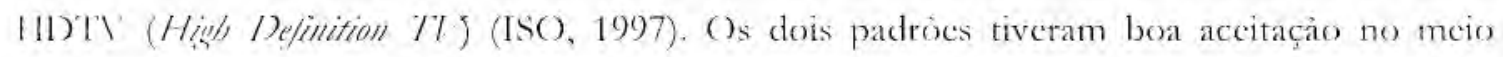
computacional e no mercado, causando um grande impacto na indústria cletrôtnica: operadoras de IV a cabo, companhias de telecomunicaçós e empresas de software e hardware têm demons trado um interesse crescente por multimídia c tecnologias associadas. Esta tendência tem acelerado o crescimento da utilização de CD-ROM e da WWW (W"orld Wide Wéeb), por exemplo.

() principal objetivo do MPF(G-2, em termos de vídeo, é definir um formato que pode ser usado para clescrever um bitstream de video codificado. Fsse bitstream de vídeo é a saída de um processo de colificaçào, o qual comprime a informação do vídeo. $\mathrm{MPEG}$-2 nào especifica o método de undificaçào, somente define o bitstram resultante. Além disso, especifica como decodificar esse libstrme. Num primcito instante, isto poderia ser visto como um problema. Intretanto, isto permuce que o processo seja mantido em aberto para o aprimoramento, por excmplo, reduzindo o tempo de codificação ou aumentando a qualidade da imagem. 
() processo de compressão do padrào MPEG utiliza, basicamente, DCl para separar informaçoses de frequências altas das frequèncias baixas. Uma matri\% de quantizaçăo com cerficrentes é utilizada para dividir os valores obtides por uma matriz gerada pelo l)C 1 , o que torna "\%ero" uma série de cocficientes (podendo descartá-los na compressào). As matrizes de quantraçào podem ser padrão ou definidas pelo usuário.

() nível de quantizaçào (e a taxa de compressào, conseqüentemente) pode ser ajustado por uma escala de fatores que é fornecida para cada slice (série de macro-blocos, contendo informaçòcs sobre onde exibir esses macro-blocos na tela) e pode opcionalmente ser redefinida para cada macro-bloco (quatro blocos, com valores de luminância, mais um número de blocos com valores de crominância). Vale ressaltar que cada bloco contém oito linhas, com cada linha contendo oito anostras de valores de luminância e crominància. Isto resulta $\mathrm{cm}$ um total de 64 valores de crominància c luminância para definir um bloco.

1) peris do processo DCT, os coeficientes para crescimento das frequências sảo distribuídos em torma de "zig-zag". O processo de quantização gera um alto número de zeros em alta frequência c aprior or rastreamento da matriz dos coeficientes resultantes na mesma ordenação "zigz-zag", wora-se relativamente fácil codificar a linha de números resultantes de forma eficiente, utilizande-sc a técnica de codificaçào T'ariable Length. A Figura 2-1 apresenta o processo de quantizaçảo.

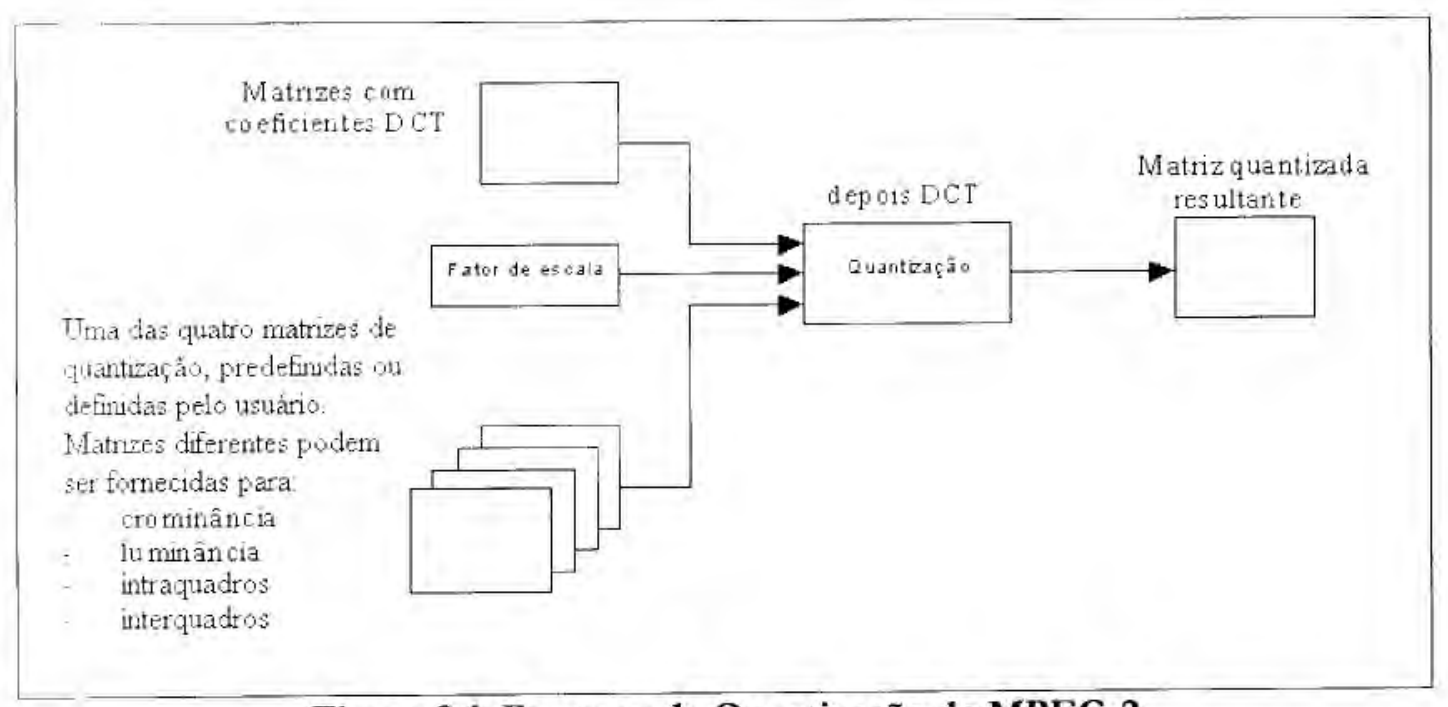

Figura 2-1: Processo de Quantização do MPEG-2 
$I$ ctapa scguinte é o uso da codificação l arzable Length (VI) ou Run-level, que codifica a sequencia de coeficientes \%erados pelo DCT através de um determinado código para um padrào especifico de cocficientes. $A$ interpretação destes códigos retorna dois valores; um valor (Imit) especifica o número de zeros iniciais em face aos coeficientes que não sào zcros; o outro valor (level) í o coeficiente real. A Figura 2-2 ilustra a codificaçào lariable Length.

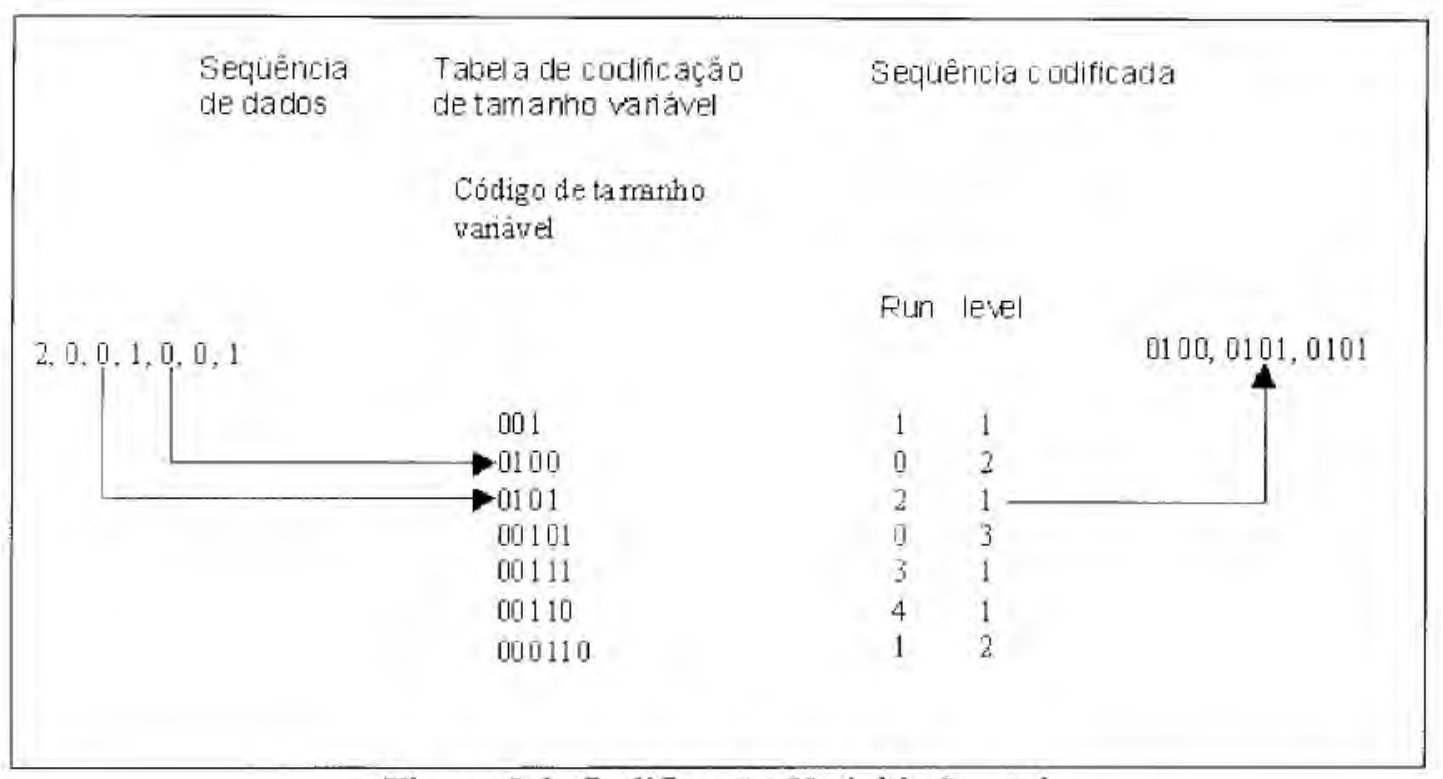

\section{Figura 2-2: Codificação Variable Length}

I estimativa de movimento é o próximo passo para a compressào MPLG e seu objetivo é ielenuticar regioes na imagem que podem ser encontradas nas imagens scguintes. liste processo utiliza macro-blocos como unidades básicas para comparaçáo. Para cada macro-bloco, o codificador procura na imagem anterior, ou na imagem anterior e na posterior, por um macrobloco que combina ou quase combina com o macro-bloco atual. Se o macro-bloco for cncontrado, a diferença entre este macro-bloco e o macro-bloco atual é calculada. $A$ diferença resultane soffe primeiramente uma codificaço DC:T e depois, funto com o vetor de movimento (i) macoro-bloco, sofre a codificação VI. U'm vetor de movimento é usado para identificar o macro-bloco na imagem anterior ou posterior.

\section{5 - A Transformada Wavelet Daub 4}

Parecicla com a transformada rápida de Fourier (FFT - Futt Fourier Thansfarm) (Elliot, 1982), a unastermada discreta navelet (DW' - discret wavelet fransform) (Daubechies, 1992) é rápida e linear, 
" pode operar sobre um vetor de dados que tem tamanho igual a uma potência de 2 (dois) e maior do que zero (Press, 1992). Ainda comparando a DW' com a IFI, tem-se que a transturmada moteté inversivel cortogonal, sendo que sua transformada inversa, yuando vista comes uma grande matrì, ć simplesmente a transposta da matri\% transformada.

Lim comjunto particular de wavelets é definido por um conjunto particular de números, que sào chamados coeficientes de filtros wavelets. Uma das classes de coeficientes é conhecida por Daubechies (levando o nome de seu descobridor (Daubechies, 1992)), e dentre os vários tucmbres, a transformada mais simples apresenta apenas 4 coeficientes $\left(c_{i b}, c_{1}, c_{2}, c_{3}\right)$, sendo chamala de Daubechies 4 (Daub4).

A Figura 2-3 apresenta a matriz. Daub4, que deve ser multiplicada por um vetor de dados (os espaçes em branco implicam em zeros), sendo que os valores dos coeficientes são:

- $\mathrm{c}_{\mathrm{ig}}=0.482962$;

- $c_{\mathrm{t}}=0.8365163$

- $c_{,}=0.2241438$;

- $c_{3}=-0.1294095$.

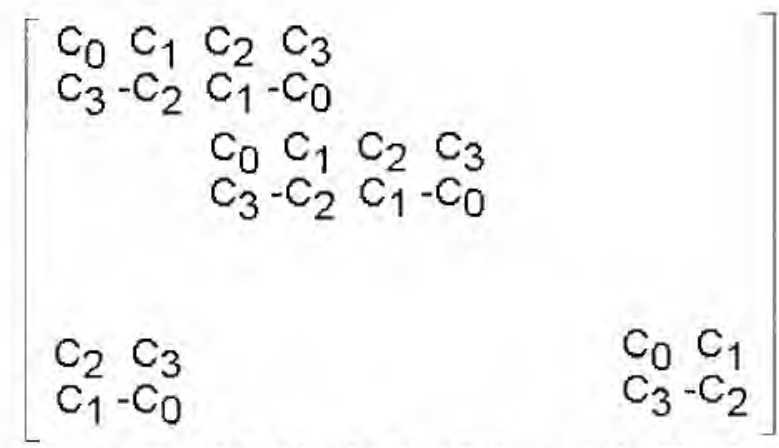

Figura 2-3: Matriz de Coeficientes da Daub4

Para aplicar a Daubt sobre uma imagem, o primciro passo consiste da transformaçào da imagem em una matri\% de dados. lim seguida, define-se um vetor da matriz imagem, formado pela primera coluna da matri\%. Fintào, multiplica-se a matrì de cocficientes pelo vetor da imagem, come i mostrado na Figura 2-4. 


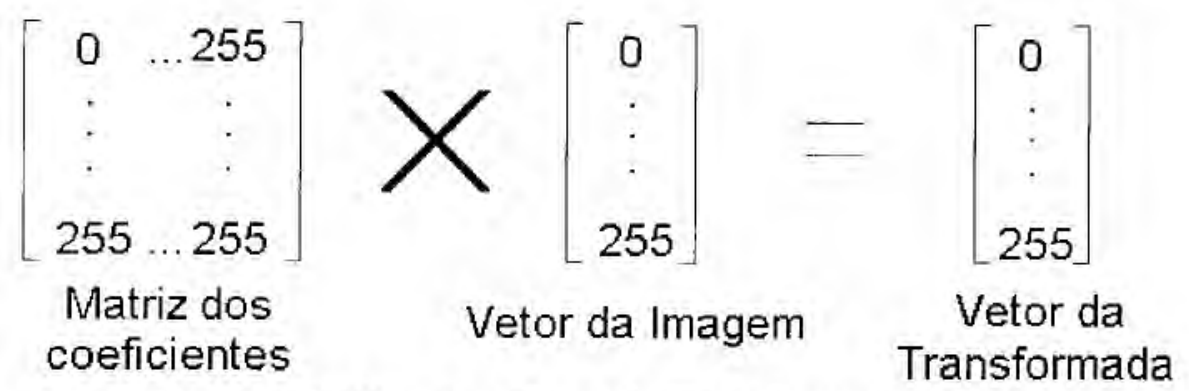

Figura 2-4: Primeiro Passo da Transformada Wavelet

Iim scyuida, multiplica-se apenas a metade inferior do vetor resultante pela matriz de coeficrentes, e repete-se esse pasșo enquanto o vetor for maior que o número de cocficientes da Iransfinmada. I figura 2-5 mostra os valores as serem multiplicados da matri\% da imagem.

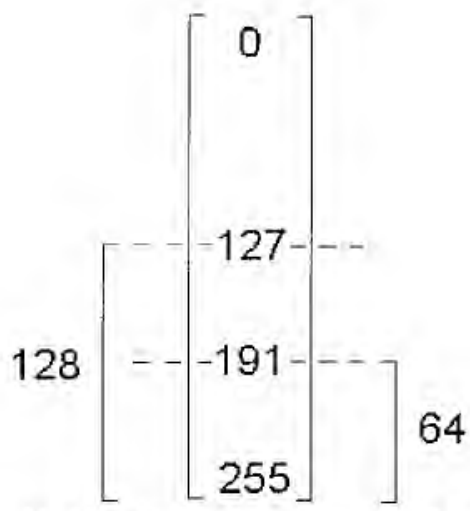

Figura 2-5: Vetor da Imagem a ser Transformada

\section{6 - Compressão LZW}

I compressào LZW tem suas raizes no trabalho de Jacob Ziv e Abraham J.cmpcl. Fm 1977, eles publicaram um artigo sobre compressào de "janelas-deslizantes", e seguiram com outro artigo em 1978 sobre compressão baseada em "dicionários" ('Liv et al, 1978). Esses algorimos foram chamades de $1: 277$ e $1: 778$, respectivamente. Jim 1984, lerry Welch fez uma modificaçâte no L.7.78, acrescentando o "W" ao nome desse popular algoritmo de compressào (Welch, 1984). O alyorimo $1 . Z W$ C de fácil compreensào e apresenta excelentes resultados se comparado a outros algoritmos, como seus antecessores (LZ77 e LZ178) ou Huffman (Nelson, 1988). 
Muitos arquivos possucm certas cadeias de bytes que sc repetem. $\Lambda$ compressão LZW utiliza um dicionaro e busca padroes repetidos dentro de um strean de bytes. Scmpre que houver um padrate yue se repete, a compactaçao $L Z W$ remove cóplas repetidas e insere um pontciro para o padrà original. A compressão L/KW nào apresenta perda de dados (losices).

() primciros 256 códigos do dicionário sào padronizados, formando um conjunto padrào de caracteres ( 0 até 255), cnquanto os códigos de 255 até 4095 se referem a sub-cadeias existentes no Irram yue estiver sendo processado. $\Lambda$ ssim, o código gerado pelo algoritmo LZWW pode possuir tamathos variaclo, mas sempre será maior do que o tamanho de um caractere (1 byté), do código padrás. O) algoritmo de compressão I.ZWW é relativamente simples como mostra a Figura 2-6.

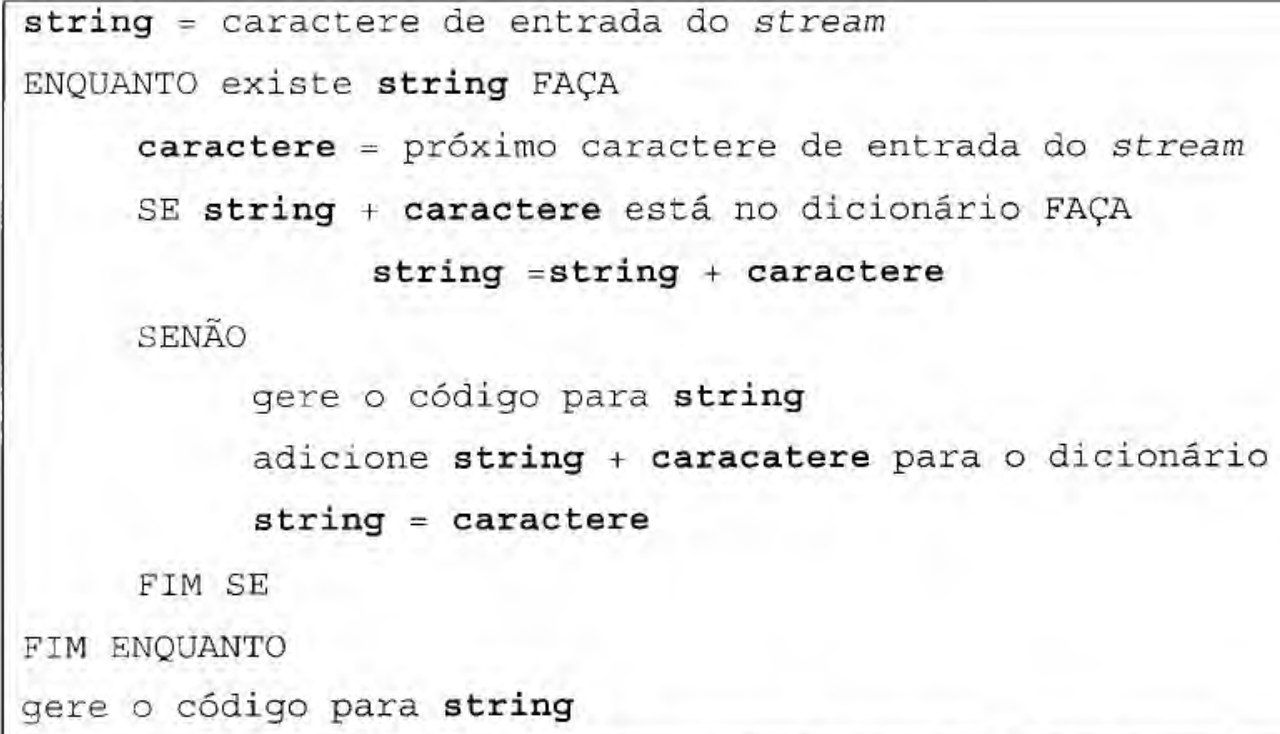

\section{Figura 2-6: Algoritmo de Codificação LZW}

\section{7 - Considerações Finais}

() padtồ de compressào de vídeo sào métodos que podem diminuir o espaço de armaznamento $\mathrm{c}$ a largura de banda necessária para transmissão, sendo a compressào interquadros mais cficiente do que a intraquadros. No entanto, apresenta maior complexidade para ser implementada. As transformadas mavelets, em conjunto com técnicas de codificaçào, podem ser urilizadas também para compressào de vídeo. 
No proximo capitulo, será apresentado o protocolo IPv6, que deve substituir a vcrsào atual do protecolo IP (versào 4), adicionando novas funcionalidades e maior eficiência para muitas aplicaceses, incluindo transmissóes de vídco. lambém serào explicadas técnicas de multicastung nos protecenes TPvt, IPvG e no Mbonc, além do protocolo R'I'P, utilizado para aplicaçóes que requèram exibiçào em tempo real. 


\section{Capitulo}

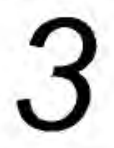

\section{Protocolos e Técnicas de Transmissão de Dados}

\section{1 - Considerações Iniciais}

() IPv G c a nova geraçào do protocolo IP, criado para substituir a versào atual (versão 4), de cujo o número de endereços possiveis está se esgotando, além de proporcionar melhor desempenho e nevals funcionalidades, como o suporte à qualidade de serviço, o que pode vir a ser de muita valia para iransmissào de vídeo.

I técnica de multicasting, independente do protocolo com o qual se efetua a transmissào de vídeo, prode economizar largura de banda da rede e diminuir o processamento $\mathrm{em}$ um servidor de vídeo (os retcadores e chaves da rede é que sào responsáveis com a resoluçào de envio de pacotes). $\Lambda$ fecnicat mulficat sera apresentada para os protocolos IPv4 e IPvG, e na rede virtual Mbone.

L'm dos modos de garantir que a transmissào de dados ocorra em tempo real, é através de um protucolo yue possa transmitir os dados de acordo com uma qualidade previamente definida. $O$ protecole utilizado como padrào na Internet para esse tipo de transmissào de dados ć o RTP (Real-Tine Thashopar Protocot).

Liste capítulo apresenta as tecnologias supra-rclacionadas e que foram utilizadas no descunvelvimento de duas aplicaçòcs cliente/scrvidor de vídeo com suporte a multicustung, no contexto no qual estc trabalho cstá inscrido. 


\section{$3.2-\operatorname{IPv} 6$}

\subsection{1 - Problemas do IPv4}

() protrocolo IPv4 foi projetado há quase três décadas atrás e, cmbora tenha alcançado um respentivel sucesso, algumas melhorias tiveram que ser feitas para que o endereçamento e roteancutos de pacotes nào se tornem inviáveis $\mathrm{cm}$ um futuro próximo. O espaço de cnderecamento é a mais visivel melhoria a ser feita cm relaçào ao protocolo, alèm da performance e da forma como os cabeçalhos sào projetados e usados.

I subsitucicano do Il'vt obriga que todo sistema que o utilize deva ser atualizado, o que nào é muito simples de ser feito por grandes corporaçòes. Existem milhòes de sistemas operando com difercuntes versōes do TCP/IP, c vários sistemas operacionais e plataformas de bardware.. E extrematmente dificil que todos esses sistemas sejam atualizados ao mesmo tempo. Sc o problema de II' + fosse apenas a falta de endereços disponiveis, poder-se-ia conviver com o problema por algum tempo, com as atuais ferramentas e técnicas de comunicaçào de dados, tais como subredes, Iradução de endereço de rede, dentre outras. Porém, existem outros problemas no IPvt, rats como escalabilidade, problemas administrativos, dificuldades de roteamento, melhoria nos servicus ce entrega dos dados com qualidade e segurança.

\subsection{2 - Caracteristicas do IPv6}

Os atuais protocolos IP utilizados na Internet nào foram projetados para fornecer suportc a serviçus de tempo real e à qualidade de serviço, necessários $\mathrm{cm}$ aplicaçòes distribuídas como uransiçice bancárias e transmissào de dados multimídia. Nlém de redes com alta velocidade e larguta de banda passante, aplicações como estas necessitam muitas vezes de um tipo de serviço diferente do serviço padrào oferecido, sendo preciso negociar os requisitos para a transmissào.

Visande fornecer suporte ao grande leque de novas aplicaçóes possiveis via Internet, além dos probletnas de endereçamento, tềm surgido diversas propostas de novos protocolos, e dentre elas está o IPng (Intenet Protocol next genteration) ou IPv6 (Deering, 1995).

() Iminet Protocol version 6 ć o nome formal da nova geraçào de protocolos IP (IPng). O IPv6 foi projetide como uma cvoluçào do I1'v4, sem realizar mudatıças radicais, permitindo que os dois 
protocolos coexistam e interajam, $\mathrm{c}$ permitindo que a instalaçào do novo protocolo seja realizada de mancira simplificada. As funçòes que apresentam bom desempenho no IPv4 foram mantidas, (-) que nao funcionava a contento fol removido. As mudanças do Il'vo em relaçào ao I1'v4 (theontram-se nas seguintes categorias (Loshin, 1999):

- Expansão das capacidades de roteamento e endereçamento: o IPv6 aumenta o ramanho do endercço IP de 32 para 128 bits para suportar mais níveis de endereçamento hierárquico, um númcro muito maior de nós (um nó é um computador que pode receber (c coviar pacotes de rede) endereçáveis c permitindo a auto-configuração de nós. $A$ escalabilidade do roteamento multicast é mclhorada através da adição de um campo scope para endereço multicast. Um multicast consiste de um grupo de nós que compartilham um endereço IP chamado endereço multicast. Sua utilizaçào permite que um pacote de rede seja enviado uma única vez a todos os componentes do grupo de nós, ao invés de chviar (1) mesino pacote para cada componente do grupo;

- Novo tipo de endereço: foi definido um novo tipo de endereço, chamado anyast, que tcm por funçào identificar conjuntos de nós onde um pacote cnviado para um endereço mincast é entreguc a um dos nós do conjunto. $O$ uso de endereços anycast $\mathrm{cm}$ fontes roteadoras Il'v6 permite aos nós controlar o caminho pelo qual seu tráfego flui;

- Simplificação do formato do cabeçalho (header): alguns campos de cabeçalho do IPv4 foram sobrepostos ou tornaram-se opcionais, para reduzir o custo de processamento no tratamento de pacotes e para manter o custo de banda passante do cabeçalho IPv6 tảo pequeno quanto possível, a despeito do aumento no tamanho do cndereço. Mesmo sendo o tamanho do endereço do IPvo quatro vees maior que o do IPvt, o cabeçalho do IPv6 é apenas duas ve\%es maior que o do IPv4 (a figura 3-1 mostra o cabeçalho do IPv4) (Stevens, 1998);

- Melhoria no suporte a opções: mudanças na maneira como as opçoes do cabeçalho IP sà codificadas permitem um envio mais eficiente, menos limiles no tamanho das opçoes, c. mais tlexibilidade para introduzir novas opçòes no futuro; 
- Suporte à qualidade de serviço: um novo suporte ć adicionado para permitir a nomeaçào (labeling g) de pacotes pertencentes a um streamde tráfego particular para o qual o umissor requisita tratamento especial, tal como uma qualidade de serviço nào padrào ou serviço de tempo real;

- Suporte à autenticação e à privacidade: o IPv6 inclui definiçòes de extensões, as quais fornccem suporte à autenticaçào, intcgridade dos dados e confidencialidade. Isto é incluído como um elemento básico do IPv6 c irá ser fornecido em todas as implementaçòes. O protocolo IPv6 consiste de duas partes: o cabeçalho básico IPvo (Figura 3-2) e os cabeçalhos de extensào II'v6.

\begin{tabular}{|c|c|c|c|c|}
\hline Versão & $\begin{array}{c}\text { Tamanho } \\
\text { do } \\
\text { Cabeçalho }\end{array}$ & $\begin{array}{c}\text { Tipo de } \\
\text { Serviço }\end{array}$ & \multicolumn{2}{|c|}{ Tamanho Total (em bytes) } \\
\hline \multicolumn{3}{|c|}{ dentificação } & 0 & DF MF Offset de Framentação \\
\hline $\begin{array}{c}\text { Tempo de Vida } \\
\text { (TTL - Time to Live) }\end{array}$ & Protocolo & Checksum do Cabeçalho \\
\hline \multicolumn{3}{|c|}{ Endereço Fonte (32 bits) } \\
\hline \multicolumn{3}{|c|}{ Endereço Destino (32 bits) } \\
\hline \multicolumn{3}{|c|}{ Opções } \\
\hline \multicolumn{3}{|c|}{ Dados } \\
\hline
\end{tabular}

Figura 3-1: Cabeçalho do Protocolo IPv4

\begin{tabular}{|c|c|c|}
\hline Versão & Prioridade & Label do Stream \\
\hline Tamanho dos Dados & Próximo Cabeçalho & Limite de Saltos \\
\hline \multicolumn{3}{|c|}{ Endereço Fonte (128 bits) } \\
\hline \multicolumn{3}{|c|}{ Endereço Destino (128 bits) } \\
\hline
\end{tabular}

Figura 3-2: Cabeçalho do Protocolo IPv6

\subsection{3 - Representação do Endereço IPv6}

() Il'v apresenta uma nova notaço de endereços, para evitar que estes se tornem demasiadamente longos. Assim, os endereços Il’v6 sào escritos como oito números hexadecimais separados por ":". Cada grupo representa 16 bits: 


\section{FFE:3100:0000:0000:0000:0000:0000:1111}

Devido a sua estrutura, os endereços $\operatorname{Pv} 6$ podem apresentar grande número de zeros. Assim, para simplificar a notação, utiliza-se o símbolo "::" para representar vátios grupos de 16 bits $\mathrm{de}$ valor zcro:

3FFE:3100::1111 cquivalc a 3FFE:3100:0000:0000:0000:0000:0000:0000:1111

\subsection{4 - Endereçamento IPv6}

() sendereços IPv6 sào identificadores para interfaces individuais e conjuntos de interfaces. Os enderecos IPvG sào atribuídos a interfaces, não a nós. Como cada interface pertence a um único nó, qualyuer um destes endereços tunicust de interfaces de nós pode ser usado como identificador para o nó. Uima única interface pode receber múltiplos tipos de endereços.

I lá tries tipos de endercços IPv6: o unicast, o amycaste o multicast. Não há endereços broadcast no IPv6, pois sua funçào foi suprida pelos endereços mulficas\% O endereço mnirati identifica apenas una inlerface. Um pacote destinado a um endereço untossté enviado diretamente para a interface associada ao endereço. Tsse tipo de endereçamento identifica uma única interface IPv6. Caso uma máquina contenha várias interfaces, cada uma delas conterá seu próprio endereço de 128 bits.

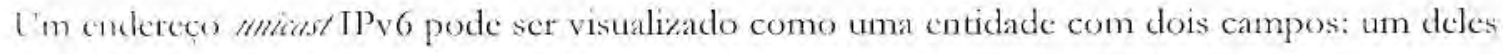
indica a rede e o outro uma interface na rede. () identificador de rede pode ser separado $\mathrm{cm}$ partes diferentes, identificando anidades de rede diferentes. Uma visào destas duas partes, contendo o ID da interface c o prefixo da sub-rede, pode ser visualizada na Figura 3-3.

N Bits 128 - $\mathrm{N}$ bits

\begin{tabular}{|c|c|}
\hline Prefixo da Subrede & ID da interface \\
\hline
\end{tabular}

Figura 3-3: Endereço Unicast IPv6

() entereço anjastidentifica um grupo de interfaces de nós diferentes. Úm pacote destinado a um cndereço alycast é enviado para uma das interfaces identificadas pelo endereço. 
Lispecificamente, o pacote é cnviado para a interface mais próxima de acordo com a medida de distâncta do protocolo de roteamcnto. O formato de um cndeteço anycast pode scr visualizado na

Figura 3-4.

\begin{tabular}{|c|c|}
\multicolumn{1}{c|}{ N Bits } & $128-\mathrm{N}$ bits \\
\hline Prefixo da Subrede & $0000 \ldots 0000$ \\
\hline \multicolumn{2}{|c|}{ Figura 3-4: Endereço Anycast IPv6 }
\end{tabular}

Figura 3-4: Endereço Anycast IPv6

L'm bom cxemplo de utilizaçào do cndereço anycast seria em uma seqüência de roteadorcs em um caminho. Diversos roteadores intermediários poderiam fazcr parte de um grupo anycast $\mathrm{c}$ um pacote endereçado ao grupo alcançaria o toteador que proporcionasse o menor custo. Devido à pouca cxperiencia na Internet com esse tipo de endereço, inicialmente seu uso será limitado, consickerando os seguintes casos:

- Im endereço anycast nào pode scr utilizado como endereço de origem (sourer address) de um pacole 1Pve;

- L'm endereco anteckit nào pode ser configurado num has TPv6, devendo ser associado a roteadores apenas.

Lisse tipo de endereçamento será útil na busca mais rápida de um determinado servidor ou setvicer Por exemplo, pode-se definir um grupo de servidores de nomes configurados com um enderece mulart, e o linstacessará o servidor de nomes mais próximo utilizando este endereço.

() endireço multicast, semelhante ao endereço anycast, identifica um grupo de interfaces, mas um pacotc destinado a um endereço multirast é enviado para todas as interfaces do grupo. Os memlures de um grupo sào dinatmicos: cstaçòes podem entrar ou deixar grupos a qualquer momento, nào havendo restriçòes quanto ao número de membros de um grupo, além de uma cstaçais poder participar de mais de um grupo simultaneamente. Um grupo pode ser permanente (possui um endereço conhecido, fixo) ou transiente (criado quando necessário, e descartado posteriomentc).

lixistem várias razócs pelas quais o llpvé é apropriado à nova geraçào de protocolos Internct. Lile soluciona os problemas de escalabilidadc da Internct, provê um mecanismo flexível para a 
transição do atual protocolo para o IPv6, tendo sido projetado para atender às necessidades de novos mercados, como entretenimento em rede e controle de dispositivos. O Ipv6 faz isso de uma mancira evolucionária, o que redǔ os riscos de problemas arquiteturais.

laciliclade de transição é um ponto-chave no projeto do 11 ve. Mecanismos foram construídos no IPv6 para garantir a transiçào c a compatibilidade com o IPv4. O IPv6 suporta grandes endereços hictárquicos, os quais irào permitir que a Internet continue a crescer e forneça novas capacidades de rolcamento.

1 estrufura de endereços fó projetada para suportar o tratamento de endereços de outros tipos de protocolos. Espaços foram reservados para endereçamento IPX e NSAP, facilitando a migraça desses protocolos para IPv6.

.lém do suporte a serviços de tempo real c auto-configuração, conforme citado, o 11 'v6 também supora mobilidade de nós, segurança ponto-a-ponto, seleçào de provedor c auto-reconfiguraçào.

\subsection{5 - Roteamento IPv6}

Jivalmente, as necessidades das organizaçoes diferem muito em relaçào a alguns anos atrás. l'ossuem cada ve\% mais máquinas e necessitam de algum mecanismo para diminuir a quantidade de endereços IPv4, já que estes cstào sob controlc para nào aumentar demasiadamente. Além disto, is roteadores da Internet estào com tabelas cada vez maiores. Uma rota para cada rede distinta deve ser listada em sua tabela.

() IP ( o nào possui uma noçào de classes, como ocorre no IPv4, c pode ser rolled up para proprisiles de roteamento, reduzindo drasticamente o tamanho nas tabclas padrào dos rotcadores. Um problema com essa arquitetura é que ela requer que redes sejam novamente numeridas sempre que uma organizaçào mudar de provedor.

Poren, cspera-se que o roteamento IPvg nào seja drasticamente diferente do roteamento IPv4. I:m suma, cspera-se uma melhora na eficiência e reduçào no tamanho de tabelas de roteamento. Assim, os algoritmos de roteamento necessitam de mudanças para prover melhor desempenho. A 
maiora das mudanças para que os protocolos suportem Il’v 6 está relacionada a adaptaçòes para manipular endereços IPv6 (muito maiores).

\subsection{6 - Mudança do Protocolo IPv4 para IPv6}

- Infra-cstrutura atual da Internct está baseada no protocolo $I P_{\vee} 4$, construída ao longo dos anos (Bradncr, 1996). A transiçáo para o novo protocolo IPvG, caso nào scja bem administrada, pode ter set desenvolvimento desestimulado devido ao seu custo e complexidade.

De qualquer forma, uma transição gradual precisa ser cfetuada e, para que esta transiçào não seja traumaitica, alguns mecanismos estào disponiveis, permitindo flexibilidade para a mudança de IPvt para IPv6. Essas cstratégias evitam dependêneias entre os vários elementos de rede durante ") processo de atualizaçào, c um usuário năo precisa esperar a atualizaçáo ou troca de alguns dementos de rede para atualizar seu bost de trabalho. Se isto acontecesse, um atraso na transiçào icorreria.

() ) mecanismos de transiçào para o IPv6 inclucm dois elementos principais, que trabalham independentemente:

- Camadas dual-IP em histr e roteadores: Scrvidores de nome e roteadores proverào suportc ao IPv4 e ao IPv6 durante todo o processo de transição, permitindo que nós atualizados interoperem com nós IP'v4 c IPv6 usando seus protocolos nativos;

- Linclannento IPvg sobre IPvet: llosts (c opcionalmente roteadores) podem tunclar trátego IPv6 através de topologias de roteamento IPv4 por encapsulamento. Lista capacidade permite a existência de sistemas IPv4 já instalados e o início imediato da operaça de sistemas utilizando IPv6.

Com enses desis mecanismos, designem de rede têm a liberdade de decidir qual deles abordar primetramente. Alguns sites atualizarào liostr que, incialmente, tunclarào através da estrutura de roteancnto IP 4 4. Outros atualizarào alguns ou todos os roteadores para camadas dual-IP.

\footnotetext{
3 O processo de tunelamento consiste em configurar dois conjuntos de máquinas com um protocolo e ligar os dois conjuntos com uma rede que opere com outro protocolo.
} 


\subsubsection{Utilização do IPv6}

() sistema operacional Linux possui suporte ao protocolo IPv6. As versòes do Red Hat 6.2 e Shackinare 7.0, com kernel 2.2.x ou superior, possuem aplicaçòes de redes que suportam o novo protucolo, como por exemplo, o ifonfig, telnet, dentre outras. Lim versoes do Linux em que as aplicacoes nà suportam o 11 ve nativamente, cncontra-se na Internet para doneload um keit clatmalo "met-kil", além de outros aplicatives adicionais, desenvolvidos por Peter Bieringer, precurser do IPv6 no linux (Bieringer, 2000).

1)ara que as interfaces de rede possam ser configuradas com endereços $\mathrm{Il}^{\mathrm{v}} \mathrm{v}$, uma recompilaçào do kem é necessária, habilitando-se o protocolo nas opçòes de rede. Uma vez habilitado o protecrele, as configuraçòes das interfaces a das rotas podem ser feitas usando-se comandos cspecificos de configuraçào de interface e de rotas. Um cxemplo, usado na configuraçào das máqunas utilizadas no ambiente de desenvolvimento destc trabalho, foi o comando "ifron/ig etbo $/ e(t):\left(2:(): 1: 1 / 6 f^{\prime}\right.$, que criou uma entrada no arquivo de roteamento para o prefixo de rede "fect 1: 1:0:1::" através da interface etherwet (etho) c configurou o endereço da interface para "fect:1:(1:1::1". () roteamento para os endereços mentricasting (iniciados com "ff") c a configuraçầo de un endercẹo com escopo de links nas interfaces de rede são feitos automaticamente na inicializaçò do sistema, após o kerne/ter sido recompilado.

() sistema operacional Windows possui um pacote especial desenvolvido pela MSRIPv6 (Microsoft Kermol $\mathrm{Il}^{2} \mathrm{v}$ - uma equipe de pesquisa da Microso/A, disponivel gratuitamente no site desta equipe (MSR, 2000).

\section{3 - Multicasting}

() prentecolos de rede mais utilizados (como os P'rotocolos de 'Transporte ISO, TCP' ou UDP') propercionam serviços de transmissão thuicast. Assim, um nó da rede somente tem a habilidade de (nviar dados para um outro nó ao mesmo tempo (Kosicur, 2000), comó é mostrado na Figura 35.

l'udar as transmissòes com um serviço tunicast sào unicamente ponto-a-ponto. Se um nó precisa ctrviar at mesma informaçà para muitos destinos, utilizando um serviço de transporte muicast, necessila de um serviço de replicaçào. 


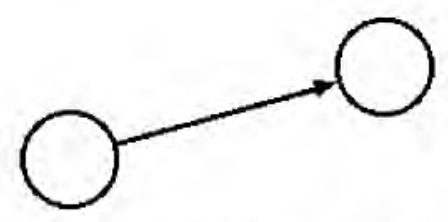

Figura 3-5: Serviço Unicast Básico

1/ultririline pode ser facilmente definido como a habilidade de enviar uma mensagem para um ou mais nós em uma opcraçào simples. Isto é diferente de utilizar uma réplica ttnicast que envia mensigens de um nó para um grupo de nós, individualmente. Isto pode ocasionar uma operação para cada nó destino, não sendo uma operaçào atômica. A Figura 3-6 mostra o serviço de transpurtc melticasting.

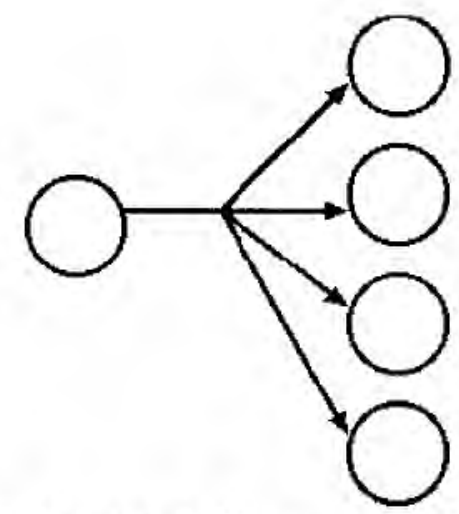

Figura 3-6: Serviço de Transporte Multicasting

11ulturabling permite que um datagrama IP scja transmitido para um conjunto de máquinas que forman um grupo de difusào seletiva, identificado por um endereço Il’ único. Lisses grupos são formates por um conjunto de máquinas, e essas máquinas podem estar espalhadas ao longo de redes fisicas distintas. $A$ cntrega de um datagrama multicast ć realizada com as mesmas caractcristicas de confiabilidade dos datagramas regulares IP, o que significa que nào há garantia contra perda, retardo, duplicaçào ou cntrega fora de ordem para nenhum dos membros do grupo (Comer, 1995).

I'm grupe pode ser permanente (possui um endereço conhecido, fixo) ou transiente (criado quande necessário, e descartado quando o número de membros atinge zero ou seu tempo de vida rermina). Multicasting pode ser urilizado em uma rede física simples ou através da Internet. 


\subsection{1 - Multicasting em IPv4}

Lima das caracteristicas de endereçamento IP é o multicasting, no qual ocorre a transmissảo de datagramas IP desde uma fonte para múltiplos destinatários de uma rede IP. Das cinco classes de cnderccamento IP, a classe D é utilizada para o IP Multicasting.

Para ctictuar mnthicasting em IPvt, ć necessário hardware especifico, onde bosts e roteadores reservam um largo conjuntos de endereços para uso de mentlicust. Quando um grupo de máquinas ywer se comunicar, escolhe um cndereço multicast particular para a comunicaçào; depois é confizurado o hardware-interface da rede para reconhecer os cndereços multicast selecionados, $\mathrm{e}$ atsinn lodas as máquinas do grupo deverào reccber uma cópia de cada pacote enviado aquele

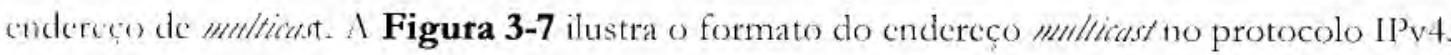

$\begin{array}{llllll}31 & 30 & 29 & 28 & 1 & 0\end{array}$

\begin{tabular}{|l|l|l|l|l|}
\hline 1 & 1 & 1 & 0 & Identificaçăo do grupo \\
\hline
\end{tabular}

Figura 3-7: Endereço Multicast IPv4 (Classe D)

1 representaçào dos endereços da classe D varia de 224.0 .0 .0 até 239.255.255.255, sendo o cndereç 224.0 .0 .0 reservado c o cndercço 224.0 .0 .1 ć permanentemente associado a todos os Luss de grupo de uma rede local, incluído também roteadores participantes no IP menticast. Os 28 luts cherdem mais baixa formam o identificador (ID) de grupo mutlicust. Quando esse endereço é mapeado para endereços Fithernet (Deering, 1995), apcnas os 23 bits de ordem mais baixa são urilizados. A 1. igura 3-8 ilustra este mapeamento.

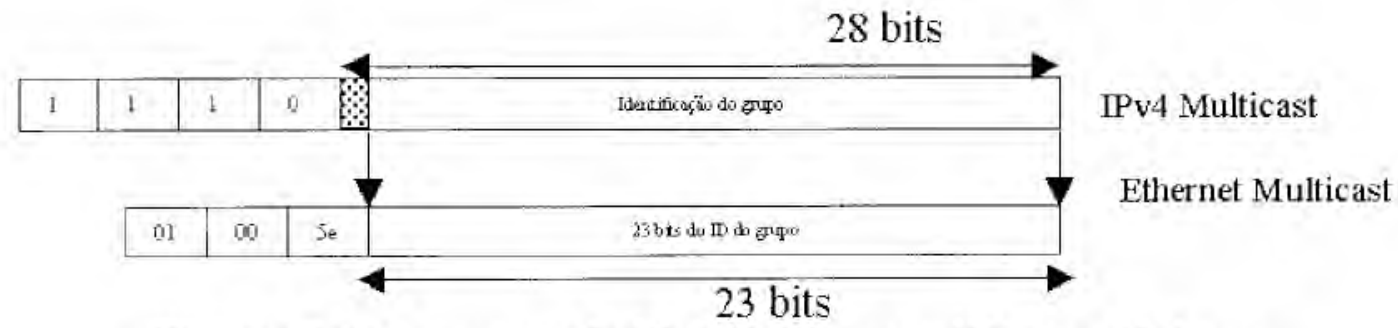

Figura 3-8: Mapeamento do IPv4 Multicast em Ethernet Multicast 
Dentre de uma rede IP pode-se ter dois tipos de usuários com características multicasting:

- () primeiro tipo refere-se a usuários que pertencem a um tipo definido pclo administrador da rede e, devido às características comuns desses usuários, o grupo multicasting sempre existe e tem um único endereço classe D) (esse grupo é também conhecido como os "yell(kirmI");

- O segundo tipo de usuários referc-se a entidades que formam grupos de intercsse por tempo limitado, sendo que a alocação ou desativação de um grupo multicasting é dinâmica (estes sào denominados "transient multicast groulps").

Ilém do hardware especifico para multicasting, os rotcadores e basts deverào usar o protocolo I(iMl' Anternet Group Management Protocol) para se comunicarem (Johnson, 1997a). O IGMP funciona como uma camada adicional sobre o IPv 4, como ć mostrado na Figura 3-9.

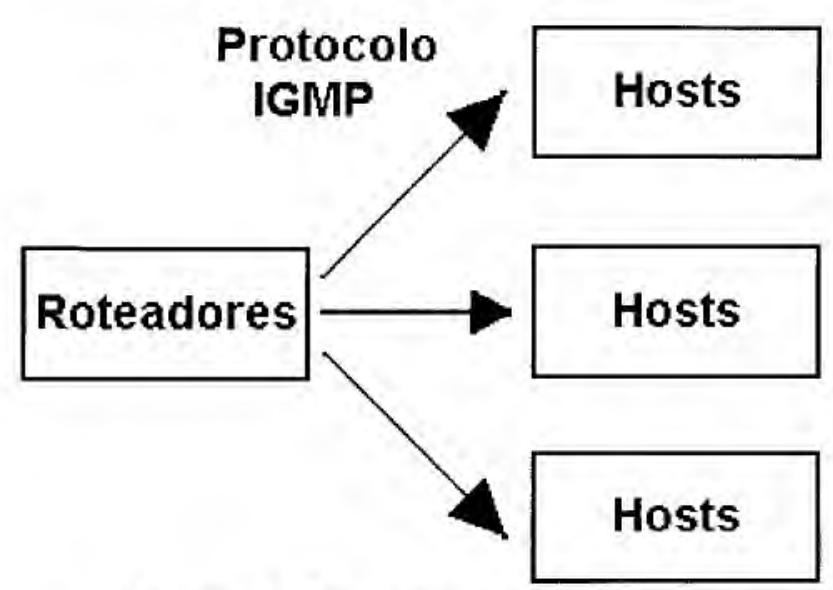

Figura 3-9: Protocolo IGMP em IPv4

Para realizar um multicusting, o usuário precisa ajustar a interface de rede de scu computador para escutar um endereço de Il' particular para o mulficat. O computador que origina o mentficast nào

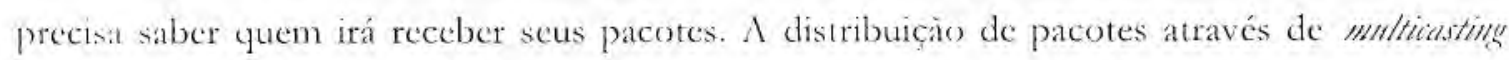
requer os seguintes mecanismos:

- ()s clientes precisam ter um modo de saber quando um multicast de interesse está disponivel;

- ()s clientes precisam ter um modo de sinalizar que querem receber o multicast, 
- I tede precisa ter um modo eficiente para rotear de mancira eficaz dados para os clientes que precisam recebê-los.

() smllicuits săe anunciados com antecedència, de forma que os clientes sabem quando um

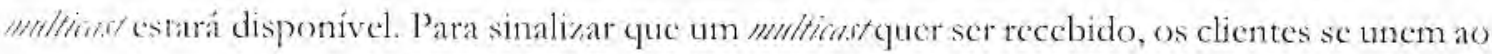
grupes nes qual o muthicast é dirigido. O Protocolo IGMP exccuta esta tarefa.

() grupus de multicast provêem várias vantagens: os clicntes podem se unir (join) ao grupo ou deixá lo (teane) a qualquer momento. Nenhum esquema mais elaborado é exigido para criar ou licenciar um grupo. Quando um grupo nào tem membros, cle deixa de existir na rede. Os grupos podem também crescer facilmente, pois quanto mais clientes se unem a um multicast, se torna mais provável que o multicast seja roteado nas proximidades destes clientes.

(Quande um cliente se une a um grupo, dois processos sào iniciados: primeiro, uma mensagem IGMI' ' enviada ao roteador local do cliente para informar esse roteador que o cliente quer recober dados cuviado ao grupo; segundo, o cliente fixa seu IP c ajusta sua interface de rede para receber o multicast no endereço do grupo e a porta. Lndereços IP classe D de multicast são cnviactos, variando de 224.0 .0 .0 a 239.255 .255 .255 .

Sempre que um roteador mentticust recebe um pacote mentticust, ele verifica a identificaçăo do grupo da mensagem e chvia o pacote somente se houver um membro daquele grupo na rede conectada a cle. () IGMP provể a informaçào requerida na última fase de envio de uma mensagem multicast a seus destinos. Porém, para enviar um pacote multicast da fonte para os nós de destino das outras redes, roteadores mutticast precisam trocar a informaçào sobre os grupos de membros dos hosks diretanente conectados a cles. Ilá muitos algoritmos diferentes para trocar informaçòes de roteancento entre os rotcadores, tais como "flood", "spanning tress", "reverse path brosdensting", c "imperm puth multicasting" (Fenner, 2000) (Johnson, 1997b).

Baseado nas informaçòcs do roteador, obtidas por um destes protocolos, scmpre que um pacote

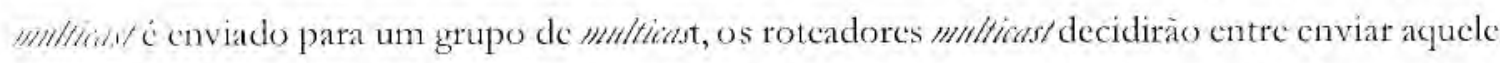
pacote para sua rede ou nào. Finalmente, o roteador analisará se existe qualquer membro daquele grupo cm suas redes fisicamente fixas, com base nas informaçōes do IGMP, e decidirá enviar o pacote ou não. 
1 classc D do IP mapela automaticamente para os endereços IEEL-802 ethernet multicast, o que simplifica a implementaçảo de multicasting de IP na Lithernet. Quando um cliente deixa um grupo, c. se sic for o únice que estiver recebendo o enrlticast naquela sub-rede particular, o rotendor deixa de enviar dados à sub-rede do cliente, liberando largura de banda naquela porção da rede.

\subsection{2 - Mbone (Multicasting Backbone)}

Nbone ou Nhulticast Backbonte ć uma rede virtual dentro da camada fisica da Internet, que possibilita uma estratégia de tráfego multimidia. Atualmente, o Mbone está em crescimento exponencial, devido às vantagens obtidas com o uso de transmissòcs por multicasting, tais como racionalizaçào quanto à utilizaçào dos recursos envolvidos, seja largura de banda, seja tempo de processamento gasto no encaminhamento de pacotes

() NlBone c uma rede virtual rodando sobre a Internet, composta de sub-redes que suportam miftirir. denominadas ilhas, conectadas umas às outras através de cnlaces ponto-a-ponto virtuais (lancmbaum, 1996a). Cada uma das ilhas é composta por uma ou mais redes locais conectando un numero de nós clientes e por um nó mrouter; que é um roteador mnlticast.

Is illas suportam IP multicnst $\mathrm{c}$ sào unidas por um limk virtual ponto-a-ponto, chamado túncl (ए,riksen, 1994). Os pacotes milticast sào encapsulados para transmissào através de túncis, aparentando screm iguais a um pacote anicastpara roteadores c sub-redes. No final do túnel, estão máyumas com razoável poder de processamento, com um sistema operacional suportando o IP menthicut e rodando um dacmon multicast ronting ou "mirouter". Os rotcadores multicast replicam os pacoles para saidas de múltiplas interfaces e túneis, assim como toda a extensào da árvore de clistribuçào multicust. A Figura 3-10 ilustra as ilhas e túneis multicast.

Lim pruncipio, o MBone utilizava um algoritmo de roteamento chamado DVMRP (Distance l'éctor

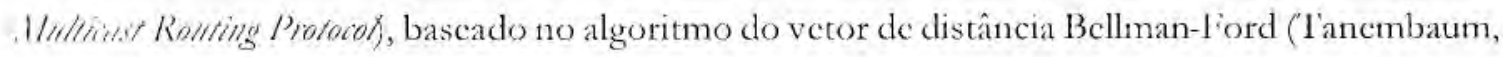
1996aj. No cntanto, é descrita a seguir a forma com que o mentricasting realmente ocorre.

Para fizer o multicast de um programa de áudio ou vídeo, um bost deve adquirir um endereço de multicur de classe $\mathrm{D}$, que funciona como uma frequêencia de rádio ou um número de canal. Cada 
mrontul envia, em intervalos regulares, um pacote de difusào IGMP limitado à sua ilha, perguntando sobre "quem" está interessado em qual canal. Os bosts que desejarem (continuar a) receler um ou mals canais, retornarào um outro pacote IG iMP como resposta. Essas respostas scràte altermadas para cvitat a sobrecarga da $1 . \mathrm{AN}$. Cada mrouter mantém uma tabcla de quais canai, devem incluir cm sua $1 \mathrm{AN}$, para evitar o desperdício de largura de banda, causado pelo imlltichi de canais que "ninguém" quer.

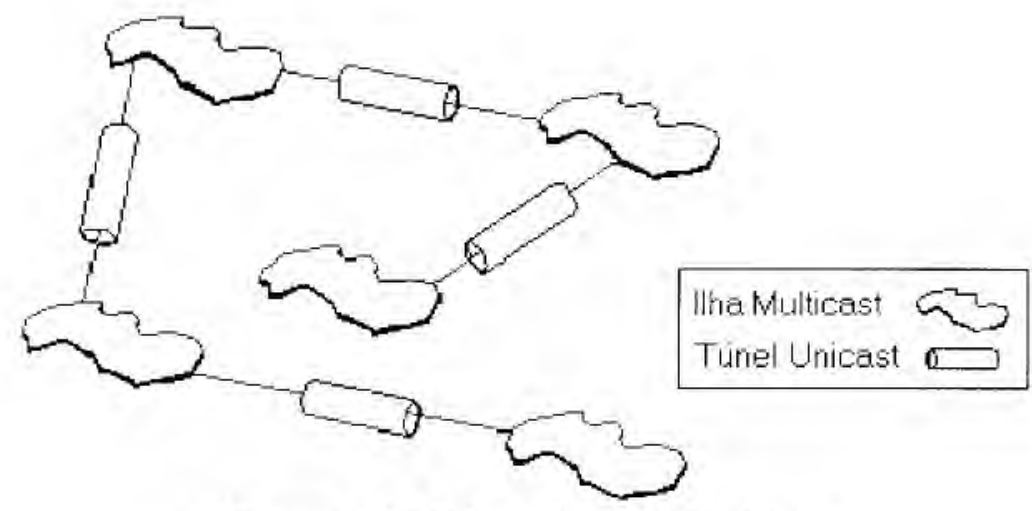

Figura 3-10: Ilhas e Túneis Multicast

() mellirast se propaga pelo MBone da seguinte maneira: quando uma fonte de áudio ou de vídeo gera um novo pacote, ela o envia por multicast utilizando o recurso de multicast do hardware. Esse pacote é recebido pelo mrouter local, que envia cópias por todos os túneis a que estiver concelado. Cada mirouter que receber o pacote, verifica se ele veio pela melhor rota, onde entendese por inclhor como sendo a rota indicada por sua tabela para chegar até a origem. Se o pacote vier pela methur rota, o mirouter enviará copias suas por todos os outros túneis. Se tiver chegado por una rota nàs ideal, o pacote será descartado.

\subsection{3 - Multicasting em IPv6}

Is funcionalidades de mnltivasting foram formalmente incorporadas ao IPv4 $\mathrm{cm} 1988, \mathrm{com}$ a definiço dos endereços classe D) e do IGMP, e ganhou força com o advento do Mbone, mas seu uso ainda nào é universal. Essas funcionalidades foram automaticamente incorporadas ao IPv6. Isso signufica que nào scrá mais necessário implementar túncis Mbonc, pois todos os liosts $\mathrm{c}$ roteaderes IPv6 deverào suportar metitticating. No IPv6, o endereço possui um formato rigido, mostrato na Figura 3-11 (Bradner, 1996). 


\begin{tabular}{|c|c|c|c|}
\hline 8 bits & 4 bits & $4 \mathrm{bits}$ & 112 bits \\
\hline 11111111 & FLAGS & ESCOPO & $\begin{array}{l}\text { ID DO } \\
\text { GRUPO }\end{array}$ \\
\hline
\end{tabular}

Figura 3-11: Endereço Multicast IPv6

() mapeamento dos endereços IPv6 multicast em endereços Eithernet multicust se dá de acordo

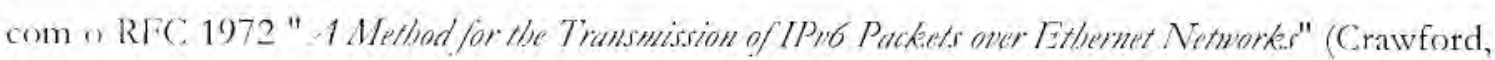
1996). c ć ilustrado na Figura 3-12.

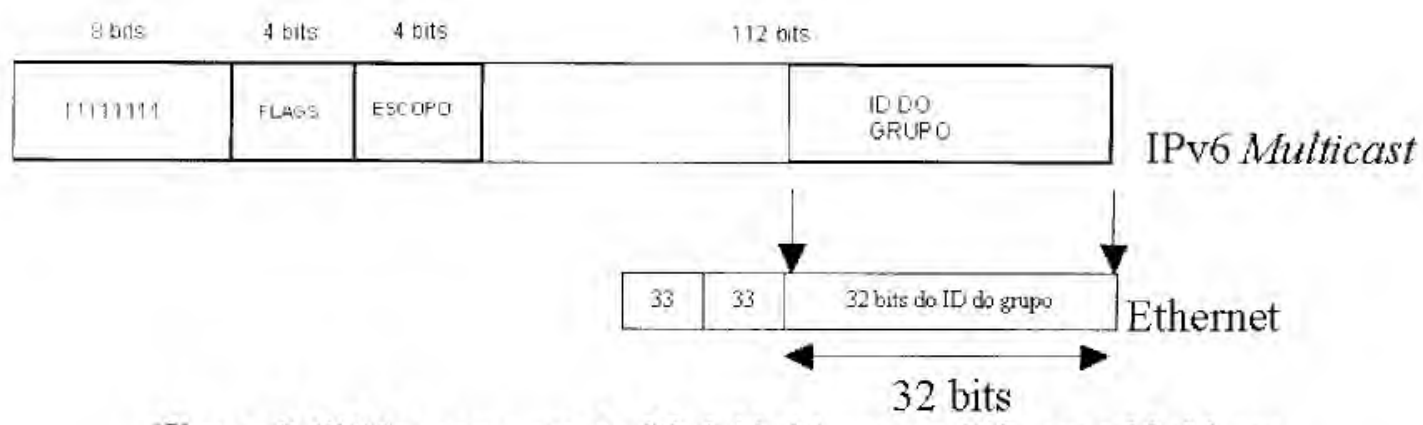

Figura 3-12 Mapeamento do IPv6 Multicast em Ethernet Multicast

L'm endereço muicast no IPv6 ć diferenciado de endereços multicast através do valor do octeto de thats al a ordem dos cndereços. O valor "Ji" identifica um endereço como um endereço multicust $(R I \div(\div 999)$.

() campo "Flags" possui informaçào sobre o grupo, que pode ser transiente (1) ou fixo (0). "Lscopo" é um campo de + bits usado para limitar o escopo do grupo multicast - se ele pode incluir somente nós da mesma rede local, mesmo site, mesma organizaçào, dentre outros. Liste campo pode adquirir os valores 1 (node-local scope), 2 (link-locat scope), 5 (site-local soope) e 8

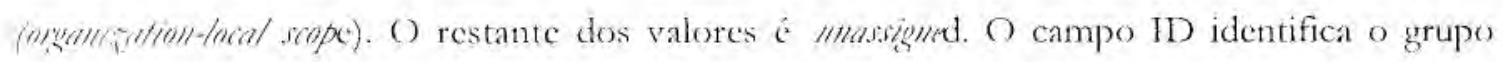
Inilfirost, ou permanente ou transiente, dentro do escopo. A seguir serão ilustrados alguns enderecos IPv6 multicasting e seus significados, de acordo com campo "Escopo". Supondo que "IO1" scja o ID de um grupo de servidores associados com endereços permanentes, tem-sc, por (exemple:

- lif:11:(1):0:0:0:0:0:101 indica todos os servidores no mesmo nó do cmissor;

- Fr:02:0:0:0:0:0:0:101 indica todos servidores no mesmo link do emissor;

- II05:0:0:0:0:0:0:101 indica todos servidores no mesmo sito do emissor; 
- IIFE:0:0:0:0:0:0:101 indica todos scrvidores na Internet.

Indereços mentficast nào associados permanentemente sào importantes apcnas dentro de um certo escope e todos endereços multicast nảo podem ser usados como endereços de origem $\mathrm{cm}$ pacotes Ilvo su aparecerem em algum lieader de roteamento. lixistem alguns endereços malticast prédefinictes:

- Reservados: FF0X:0:0:0:0:0:0:0, onde X varia de 0 a $\Gamma$;

- Todos os nós: FitoX:0:0:0:0:0:0:1, onde X varia de 1 a 2 ;

- Iodos os roteadores: 110)X:0:0:0:0:0:0:2, onde X pode ser 1, 2 ou 5;

- Endereço de nó solicitado: 1102:0:0:0:0:1:1: XX:XXXX, computado em funçào dos endereços unicust c anyeart do nó que está sendo solicitado. O endereço multicast do nó solicitado é formado tomando-se os 24 bits de ordem mais baixa do endereço c incluindo estes bits no prefixo FF02:0:0:0:0:1:FF00::/104, resultando em um endercço multicast na taixa de FF02:0:0:0:0:1:1F00:0000 a FF02:0:0:0:0:1:FFIF:FFIF:

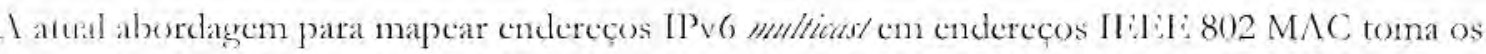
32 bus de mais baixa ordem dos endereços multicast Il'v6 e os utiliza para criar um endereço MAC (. Werdir lerros Contra) único.

\section{4 - Protocolo RTP (Real-Time Transport Protocol)}

Para ctctuar transmissòes de video em tcmpo real, como uma videoconferência, sobre a Internet ou una Intranet, existe a necessidade de receber e transmitir streams de vídco c áudio em tempo real. I seguir, será detalhado o R'I'P (Reat-lïme Transport Protocot), o protocolo de transporte utilizatie para receber e transmitir strums de aúdio e video através de redes.

\subsection{1 - Mídia Streaming}

(Quanch) uma midia é transmitida para um cliente cm tempo real o cliente pode começar a reproduzir a mídia sem ter recebido todos os dados que a compòem. Fntretanto, muitas vezes, um clínte nào pode reproduzir os dados que está recebendo, antes de receber todo o conjunto (Isso prode variar de acordo com o tipo da mídia, se existe compactaçào ou nào, por exemplo). O 
termo Nídia Itreaming é utilizado para se referir às técnicas de distribuiçào de mídia sobre a rede cmì tempo real, e em tempo de geraçào da midia que está scndo distribuída.

Iplieracoes de Mídia Straming podem ser vistas nas rádios e transmissóes de televisào via Web, c atraves delas é possivel condurir conferências com áudio e vídco através da Internet. Por possihilitar distribuiçào dinâmica de mídias interativas, Midia Streaming vem mudando o modo como as pessuas sc comunicam e acessam informaçòes, tanto na Internet com em intranets.

\subsection{2 - Protocolos para Mídia Streaming}

T'tansmitir dados multimídia através de redes em tempo real requer alta largura de banda. Isso facilita a compensaçào de perda de dados, causada por grandes atrasos no recebimentos de dados. Iransmissóes em tempo real sào muito diferentes de transmissòcs de dados estáticos, mide o mais importante é que todos os pacotes de dados possam chegar no seu destino, garanundo a integtidade dos dados. Consequentemente, protocolos utilizados para transmitir dados cstáticos nảo trabalham com a distribucçào de Mídia, Streaming.

() prenocolos I I"IP (Hyperlext Transfer Protocol) e L"I'P (File Tiansfer Pratocot) sào baseados no TCP (Thmiluision Control Protocol), que é um protocolo da camada de transporte, projetado para realizar comunicaçós com baixa largura de banda $\mathrm{cm}$ redes com altas taxas de crro ná comunicaçào. Quando um pacote é perdido ou corrompido, ele é retransmitido, o que pode causar demora em uma comunicaçào. Por csta razào, outros protocolos, abaixo da camada do I'CP, so atilizados para Mídia Streaming, sendo um deles, o UDP. () LDP é um protocolo năoconfiavel, que nào garante que cada pacote chegue onde foi enviado, nem tampouco que cheguem ordenados. O receptor năo ć capaz de compensar perda de dados, pacotes cluplicados c pacoles fora de ordem.

Como o ICP, o UDP é um protocolo da camada de transporte de baixo nivel, utilizado para servir como base para implementaçào de outros protocolos mats complexos yue podem agregar luncionalidades. O protocolo padrão de transporte em fempo real da Internct, utilizado para (ransnissào de áudio e vídeo, ć o RTP. O R'IP é definido no IFTF RFC 1889, um produto do IF:T' (Intermet Fingineering Tare. Forre). 


\subsection{3 - Serviços RTP}

O R'I'T possibilita a distribuiçào ponto-a-ponto de serviços de transmissào de dados cm tempo real, sendo um protocolo de transporte independente, utilizado sobre o protocolo UDP. A Figura 3-13 ilustra a arquitetura do protocolo.

\section{Aplicações de Tempo Real}

\begin{tabular}{|l|} 
RTCP (Real-Time Control Protocol) \\
RTP (Real-Time Transport Protocol) \\
\hline \begin{tabular}{c|c|} 
Outras Redes e Protocolos \\
de Transporte \\
(TCP, ATM, ST-II, etc.)
\end{tabular} \\
\cline { 2 - 2 }
\end{tabular}

Figura 3-13: Arquitetura RTP

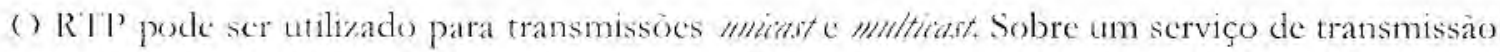
Myicai, cópias separadas de dados sào enviados da fonte para o destino, enquanto na transmissão Imulticutr apcnas uma cópia dos dados é transmitida, ficando a rede responsável pela transmissào dos dackos para diversos locais. A técnica de multicasting é mais eficiente para aplicaçóes multimída, como videoconferências. () protocolo padrảo da Internet (IP) suporta multicasting.

() R'T' permite identificar o tipo de dado que estiver sendo transmitido, determinar em que ordem os pacotes de dados chegam ao seu destino c a sincronizaçào de streaths de diferentes fontes. Pacotes de dados R'l'P nào têm garantia de chegar na ordem em que foram enviados, $\mathrm{c}$ nem dé que chegarào ao scu destino. O receptor é que fica responsável pela sua ordenação e pela detecéo de perda, utilizando as informaçòes contidas no cabeçalho do pacote.

Ipcsar do RTP nào proporcionar qualquer mecanismo para determinar o tempo de distribuiçào su prover a garantia da qualidade de serviço, ele possui um protocolo de controle (RTCP) que permile a monitoraçào da qualidade da distribuiçào dos dados. Além disso, o R'l'CP provê contrelle e mecanismos de identificaçào para transmissoes baseadas no R'I'l'. Se a qualidade de serviço é essencial para uma aplicação $\mathrm{cm}$ particular, o RTP pode ser usado sobre um protocolo de rescrva de recursos para prover serviços orientados à conexão. 


\section{5 - Considerações Finais}

Veste capítulo foram apresentadas as principais características que diferem o protocolo IPv6 do protoculo $I \mathrm{P}_{\mathrm{v}} 4$, detalhamento da arquitetura e tipos de endereços do IPv6. Além do funcionamento, algumas informaçòes foram apresentadas para configuraçào dos sistemas operactenats I inux e Windows.

O uso de multicasting ć uma forma para economizar largura de banda das redes e também recursos de noi que cstcjam transmitindo dados. $\Lambda$ s inovaçòes tecnológicas em relação ao multicasting estão sendo incorporadas aos novos protocolos que vêm surgindo, como o IPv6, que incorporou algumas técnicas do IPv4 $\mathrm{c}$ do Mbonc.

() R'I'P é um protocolo utilizado para transmissào de dados multimidia, implementado sobre outros protocolos de transporte de niveis mais baixos, possuindo características diferenciadas em relaçis aus protocolos que foram projetados para transmitir dados de mancira confiável, onde nào é aceita a perda de pacotes.

No proximo capítulo, as principais tecnologias utilizadas para o desenvolvimento deste trabalho serato detalhadas. 


\section{Tecnologias Utilizadas}

\section{1 - Considerações Iniciais}

Iste capitulo tem por objetivo apresentar as tccnologias utilizadas no descnvolvimento deste traballors. Inicialmente, ć apresentada a linguagem Java, que surgiu como uma tecnologia base para 1) descuvolvimento dos mais variados tipos de aplicaçóes, devido ao scu vasto conjunto de recurses, por ser oricntada a objetos c multiplataforma. Alguns pacotes c $\Lambda$ PIs (1pplication Prygrameming Interface) podem trazer soluçòes simples para os desenvolvedores, como a API JMF (Jam I Iediu liramemorê, uma interface para manipulaçào de áudio e video e a ferramenta JIPSY

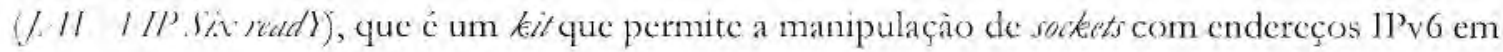
linus.

\section{2 - Linguagem Java}

1 lingungem de proggamaçăo Java foi desenvolvida pela Sun Microsystems, no início da década de 90, tendo como objetivo principal o uso de uma linguagem de programaçào que permitisse a integraçăo total de sistemas de computaçào com equipamentos eletrodomésticos. Sua sintaxe é derivada da sintaxe da linguagem $\mathrm{C}++$, sendo também orientada a objetos, c como foi feita para ser executada sobre os mais variados sistemas, também é multiplataforma. Tal funcionalidade ć pessíl ct através do processo de compilaçào que gera, a partir de um código-fontc, um código itirernc diário chamado bytecode, que é interpretado cm qualquer plataforma com suporte à Java.

De mexlo geral, as principais características da linguagem Java são (Cornell \& I Iorstman, 1997):

- Presença de recursos inultitbruaded que permitem a implementação de aplicaçôes multitarefa; 
- Itravés das bibliotecas AWT (Abstract Window Tooleit) c. Suing, a linguagem apresenta um vasto conjunto de componentes para a implementaçào de Interfaces Gráficas com o Lisuário (GUI - Graplici User's Interfac);

- Devido à sua natureza gráfica, a linguagem inclui recursos para manipulaçao de elementos gráficos independentemente do dispositivo gráfico e da plataforma operacional;

- possibilidade de inclusào de bibliotecas de propósito específico;

- presença de recursos para processamento e análise de imagens.

( )uande se cscreve um programa em Java, esse programa recube a extensào ".java" para iclentilicar o código-fonte. Os compiladores Java (com ambiente de descrnvolvimento ou nào), possucom uma MV Java (Máquina Virtual Java) que funciona como um sistema operacional neutro. O código-fonte passa por um compilador que é responsável pela compilação do códigofonte, gerando um arquivo com a extensão ".class", que é o programa-objeto gerado para esse sistcha operacional neutro. O processo de compilaçào e execuçào é aprescntado na Figura 4-1.

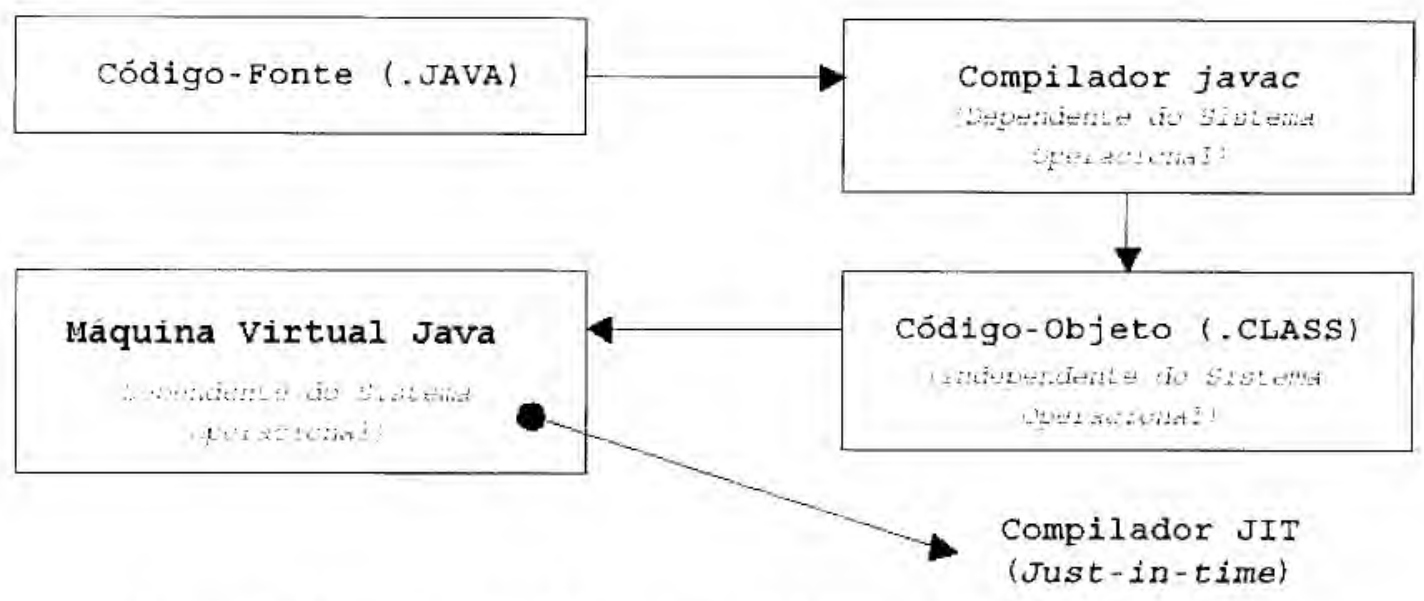

Figura 4-1: Esquema de Compilação e Execução de Programas Java

De pesse do programa-objeto, pode-se efetuar sua execuça em qualquer sistema operacional real que accite a máquina virtual Java, tais como Windows 95, MacOS, UNIX SunOS, Jinux, OS/2 Warp, dentre outros. A MV Java para execuçào de uma aplicaçào stand-alone ć dependente do sisiema opcracional, enquanto que, para a execuçào de um applet, a MV Java é dependente do navegaldor (browsics). 


\subsection{1 - Aplicações Multithreading}

No principio da computaçào paralcla, os termos "concorrência" c "multitarefa" possuíam concciros completamente distintos e eram aplicados a situaçòes também distintas. Com a cvolucio do hardware c das técnicas de programaçào, estes termos passaram a ser complenentares (Tanenbaum, 1996b).

Iintende-se por programação concorrente a implementação de técnicas que permitem a dois ou mais processos a concorrência a algum recurso comum. Nesse contexto, deve-se observar que a implementaçào de processos concorrentes exige, dentre outros fatores, a verificaçào de dispontbiliclade do recurso comum antes de utilizá-lo. Por outro lado, entende-se por multitarcfa a implementaçào de técnicas que permitem a execuçào simultânea de dois ou mais processos.

Complementando, deve-se ressaltar que técnicas de concorrência estão presentes na maioria das implementaçós de multitarefa, uma vez que a execuçăo simultânea de processos pode gerar stluaceses de concorrência (Tancnbaum, 1996b).

I presgramaço multitlerading cstende a idéia de multitarefa, fazendo com que dentro de um mesmo processo existam várias tarefas sendo executadas ao mesmo tempo, onde cada unidade computacional ê denominada thread. Quando um programa possui mais de uma unidade compuracional é denominado multithreaded, o que, cm muitos casos, pode aumentar a cficiência compuacional (desempenho). De um modo geral, o uso de threadi requer o conbecimento dos cstados de exccuçào de subprocessos. Uma thread, quando devidamente utiliæada, passa pelos seguintes cstados (Tanenbaum, 1996b):

- Instanciamento (bound): uma thread é definida em relaçào a uma classe de objetos ou outro paradigma de programaçào;

- Criação (fork): uma thirad instanciada é criada como um sub-processo que será exceutado simultancamente a outros;

- Partida (start): uma thierid criada é colocada cm cstado de "pronta para execuçào";

- Execução (run): uma thread entra no estado de cxecução e ganha um processador;

- Suspensão (suspend) : uma thread é suspensa (pausa) por um determinado intervalo de tempo; 
- Destruição (stop/destroy): uma thread ć "morta" c o processador ocupado é, entào, libcrado.

1 linguagem Java possui uma classe de objetos, denominada Thread, que contém métodos implementados para suportar todos os estados de exccuçào de uma thread, bem como cstratégias para permitir o controle eficicnte dos processos de sincronizaçào e temporizaçào (Morrison et al., 1998

\subsection{2 - Aplicações Baseadas em Comunicação Via Sockets}

() modelo de comunicaçào cliente-scrvidor, modelo arquitetural da Internet, permite a tróca de informaçòes através de uma conexào entre as aplicaçòes. Existem várias maneiras de sc estabelecer uma conexào entre dois pontos, sendo que uma delas é a comunicaçào via sackets. O processo para o estabelecimento de uma conexăo via socketsinicia-se quando um cliente envia um pedicter as survidor indicando a porta (endereço lógico) para a conexão. No servidor, um módulo de software está cm exccuçào (listenning e recebc o pedido do cliente; esse módulo sai do estado de cscuta cm que permanecia, cstabelece a conexão e passa ao estado de comunicaçào com o cliente, no qual o servidor envia os resultados processados em relaçao ao pedido do clicnte. $O$ canal estabelecido pelo socket permanece ativo até que uma das partes - cliente ou servidor encere a comunicação. $\Lambda$ Figura 4-2 (Stevens, 1998) ilustra o esquema básico de funcionamento da comunicação cliente-servidor via sockest.

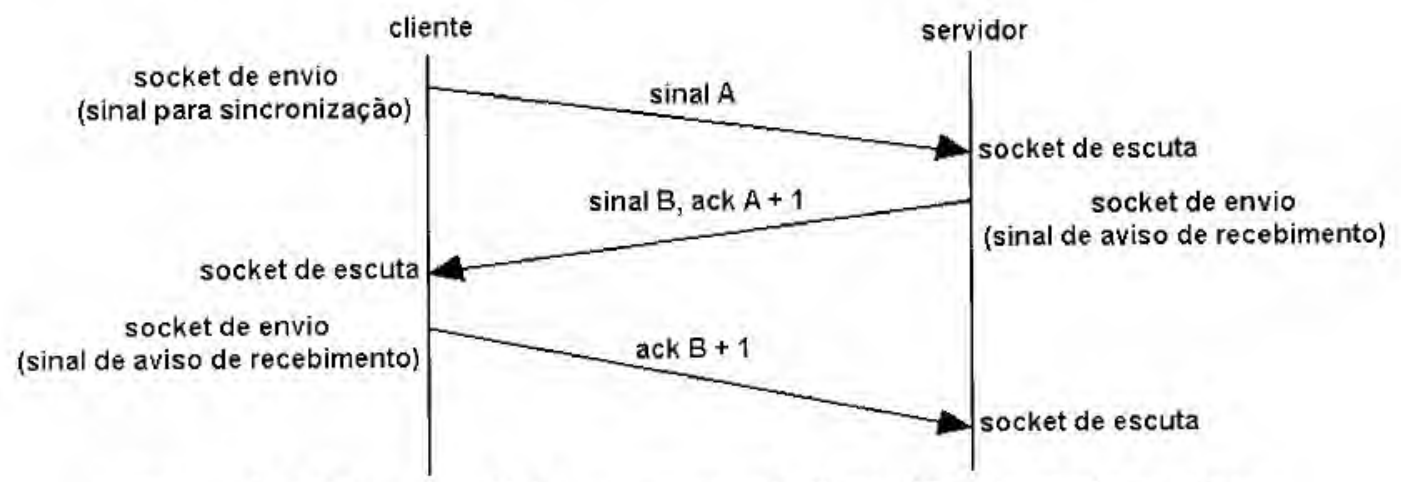

Figura 4-2: Esquema da Comunicação Cliente/Servidor via sockets 
I linguagem Java of crece os recursos nccessários para o estabelecimcnto de conexões baseadas $\mathrm{cm}$ sorkets cntre clientes e servidores (Jamsa et al., 1997), que ocultam as complexidades do estabckecimento de uma conexào com a rede e o envio de dados por meio da mesma.

\section{3 - JIPSY}

Na cscollha da linguagem para ser realizada a implementaçào deste trabalho, um fator decisivo foi 1) superte da para o protocolo IPVG, e mesmo a versao mais recente dos compiladores Java nào possuám, até então, csise suporte. Após realizar uma pesquisa na $W^{2} e$, for encontrado o pacote

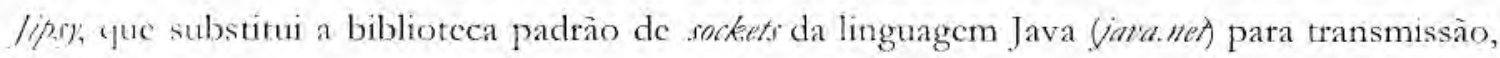
utilizando TPv6.

Lisse pacote, descnvolvido por Matthew Hanagan, da Universidade de Tecnologia de Sidney (lianagan, $2(00)$, permite que um codigo que funcione diretamente com sockets $1 \mathrm{l}$ v 4 possa ser recompilado utilizando Jipsy para operar com $1 \mathrm{P} v 6$, sendo que a única diferença no código ć o formato dos cndereços de cada protocolo.

\section{4 - API JMF (Java Media Framework)}

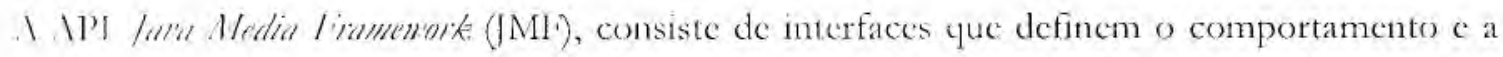
interacio de objetos usados para capturar e apresentar as mídias baseadas em tcmpo (Sun, 1999). Verificando as possibilidades dessa API, constatou-se que ela poderia ser utilizada para criar a aplicaçao cliente/servidor, mas somente para máquinas com o sistema operacional Windows. Até a últuma versào da API para o sistema operacional linux (2.1.1. beta, portada para Linux pelo yrupo) Blackdown), apenas alguns tipos específicos de compactaçào cram accitos (MPI: ( 2 2, 11261 ( 112637 , mas com um desempenho muito baixo. Além disso, mesmo com a versào da API para Windrsvs, nào seria possivel realizar transmissòes com o protocolo IPv6.

Ipesar dos problemas, a NPI JMF anda teve um papel importante no desenvolvimento da aplicacio, pois o suporte às camadas superiores da arquitciura JML, mostradas na Figura 4-3, está dispenível tanto na versào Windows quanto l inux, e permite manipulaçáo do tipo de vídeo a ser trabalhado, assim como manipulaçào de quadros individuais. 


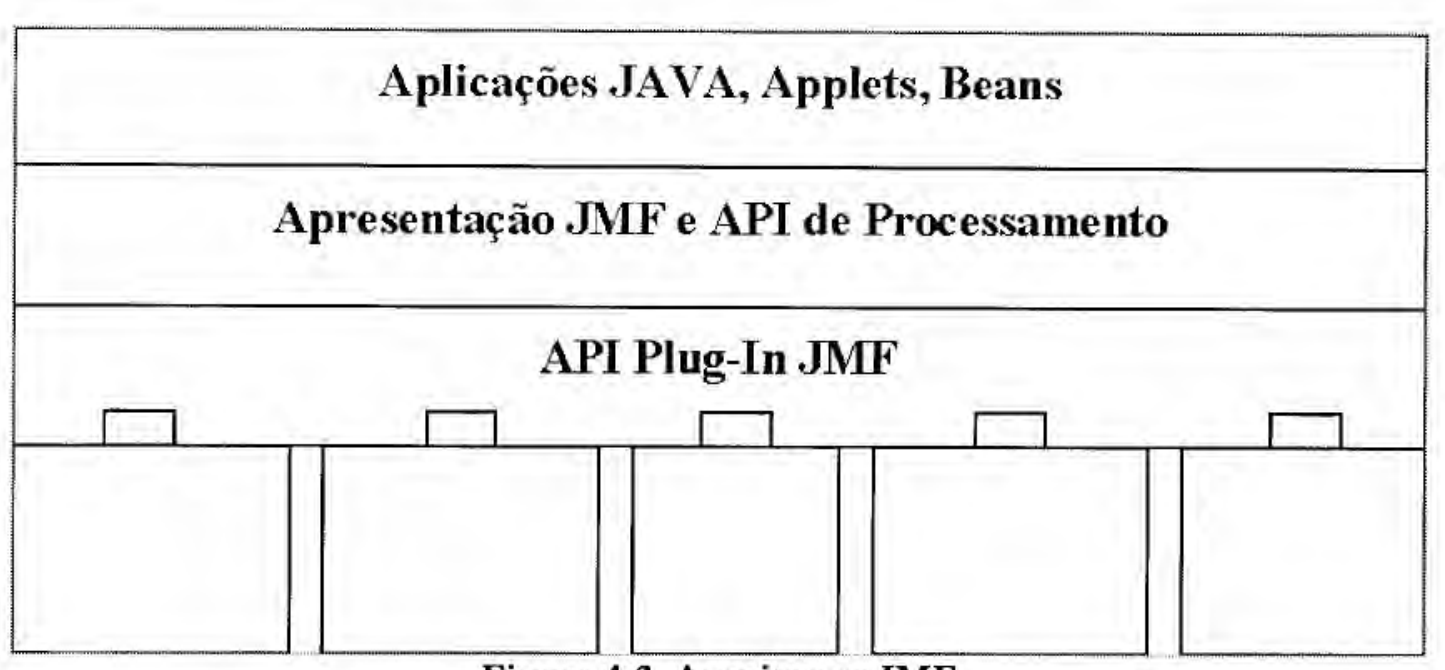

Figura 4-3: Arquitetura JMF

Lim dres elementos básicos da API JMF sào os objetos intermediários, denominados managers. leraves deles, JMl torna menos complexa a integração de novas implementaçòes de chaves de merlitecs yue podem ser utilizadas em conjunto com classes existentes na linguagem. J Ml utiliza quatre lipes de mangers:

- Manager: permite a construção de Players, Processors, Data Sources e Data Sinks.

- PackageManager: mantém o registro de pacotes de classes.

- CaptureDeviceManager: mantém o registro dos dispositivos de captura.

- PlugInManager: mantém o registro de pluge-ing de componentes de processamento.

Para a aquisiçio de quadros individuais, apenas o primeiro nível foi utilizado (Manquer). A partir de uma fonte de dados (Data. Source) cria-se um processador (Pracessor), que pode ser configurado para realizar processamentos diversos sobre o arquivo de video (a fonte de dados ou Data Source). ()s cstados do proccssador são mostrados na Figura 4-4. 


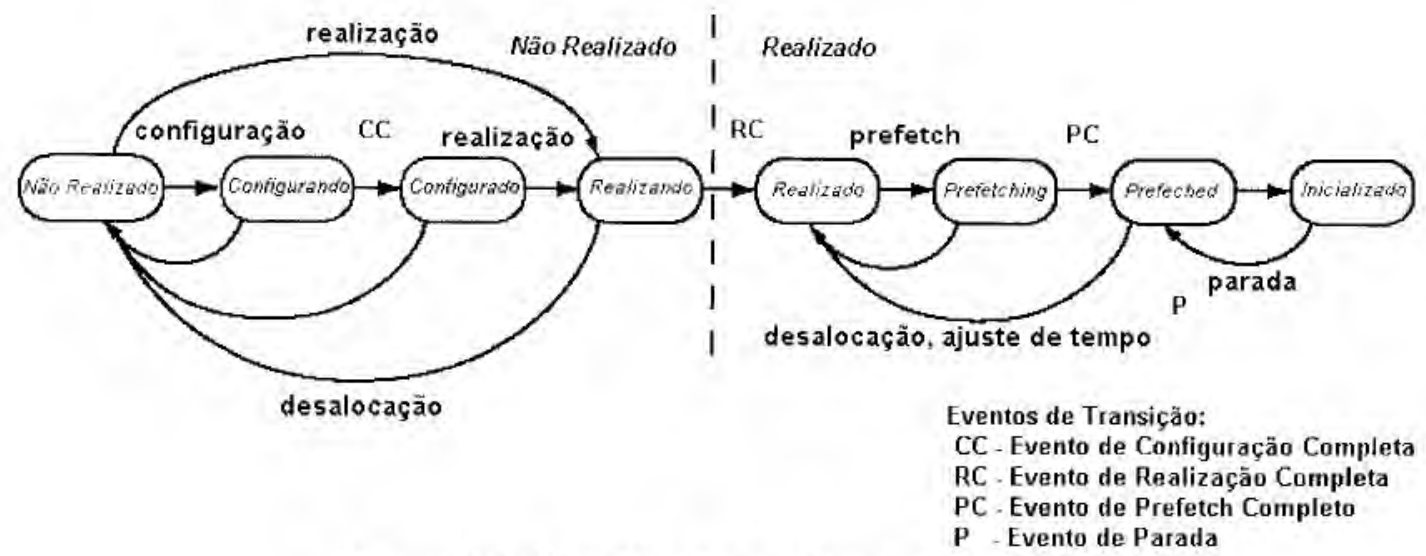

Figura 4-4: Estados de um Processador JMF

()s passos para realizar a aquisiçào de quadros individuais são mostrados a seguir:

1. Cria-se um DataSource (o arquivo do vídeo a ser processado).

2. Cria-sc um Processor (bascado no DataSource).

3. Coloca-se o Processor no estado Configurado

t. Obiém-se o controle das trucker do vídeo.

5. Determina-se qual tipo de vídeo scrá utilizado.

6. Coloca-se o Processor no estado Realizado.

7. Obićm-se o controle de quadro grabbe:

8. (obtem-se o controle sobre quadros individuais.

9. Colocat-se o Processor no estado Prefetching.

111. Realiza-se qualquer operaçào desejada com os quadros do vídco.

\section{5 - Considerações Finais}

(com o advente) da Internet, diversas tecnologias de software surgiram, muitas gratuitas c com códign aberto. Essc rrabalho utilizou principalmente este tipo de tecnologia, como o sistema operacional linux, a linguagem Java e seus pacotes (como o Jipsy) e APIs (como a JMH), pussibilitando que os resultados desse trabalho possam ser reproduzidos e utilizados com um custo minmo.

No proximo capítulo, será mostrado o ambicnte de tcstes, as implementações efetuadas e os resultados obtidos. 


\section{Capitulo}

\section{5}

\section{Ambiente de Testes e Resultados}

\section{1 - Considerações Iniciais}

Para realizar cstudos de transmissào multicurtimg com compactaçào de vídeo e suporte IPv6, necessuavamos de uma aplicaçào com essas características ou alguma aplicaçào com código aberto para que sc pudessc scr adcquá-la às necessidades. Infelizmente nào fol encontrada nenhuma aplicaçào que atendesse aos requisitos, sendo necessário a implementaçăo de uma nova aplicacio. Pelos motivos apresentados no Capítulo 4, a tecnologia Java foi escolhida juntamente coma IPI JMI' co o pacote Jipsy.

Inicialmente, foi implementada uma aplicaçăo cliente/scrvidor para transmissào de vídeo com basc toos processadores da API JML, que utilizava o protocolo RTP, c codificadores e decoclificadores de vários padròes de compressào de vídeo (JPIEG, MPLG2, 11261) da própria IPI. Infelizmente, a implementaçào dos sockets nào permitiu a utilizaçào do pacote Jiţrił que possibilitaria o uso do protocolo TPv6. Assim, foi necessário o desenvolvimento de outra aplicacio que tivesse suporte a esse protocolo, scndo toda a problemática de transmissòes multiun com pacotes UDP, processamento para fragmentaçào dos quadros e envio e recebinento de pacotes, adicionada à implementaçào.

Ipós a implementaçào estar apta a transmitir quadros descomprimidos, foi realizado um estudo para cfetuar a transmissào de quadros comprimidos, sendo avaliados os padròcs JPEG c um sutro método, proposto neste trabalho e descrito em detalhes no tópico 5.5.4-Compactação Daub4-LZW, que utiliza as transformadas Wavelets Daubbechies $4 \mathrm{e}$ a codificação $1: 2 W$. 


\section{2 - Ambiente de Testes}

() objetivo deste trabalho foi o de estudar a problemática da transmissào de vídeo utilizando Inultiusting, com compactaçào intraquadros. Para que os testes de transmissão de vídeo pudesscm ser efetuados, um ambiente de testes foi configurado utilizando-se 3 (três) PCs (Personal Compuresi), denominados It thitelsorse (servidor), Jame/(cliente), c Campari (cliente) c um bub 10/100 Mlyps da 3Com. $\lambda$ Figura 5-1 ilustra este ambiente.

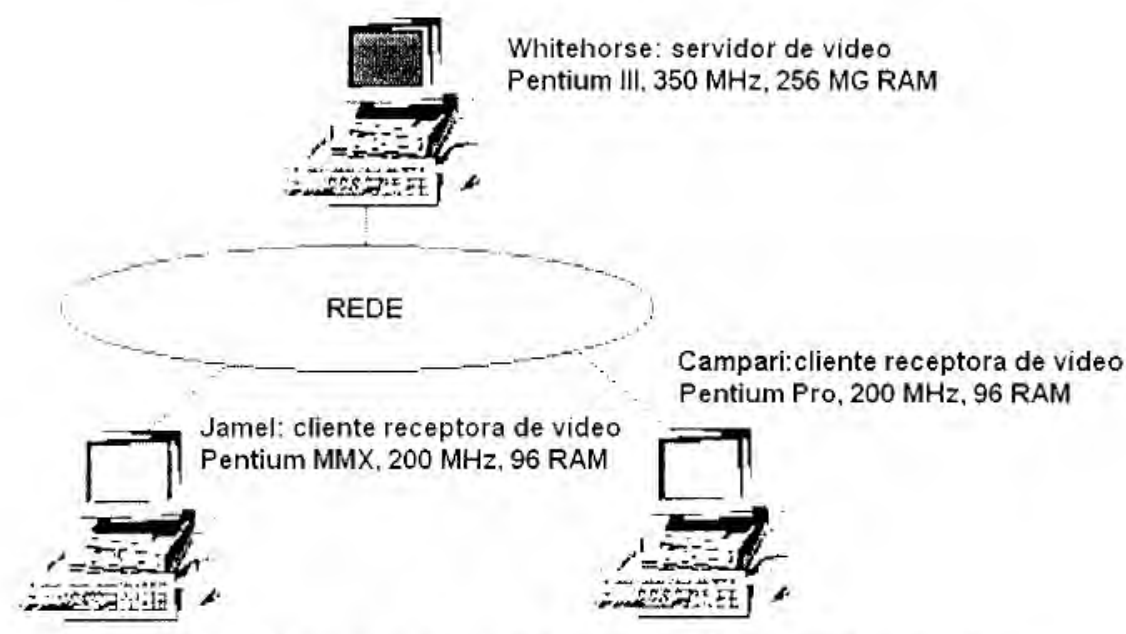

Figura 5-1: Esquema do Ambiente de Desenvolvimento

A máyuina servidora (Wlitelorse) foi configurada com 2 (dois) sistemas operacionais, o Windows N'l +11 e Linux Red Hat $6.2 \mathrm{c}$ as outras duas, apenas com o sistema operacional Linux (com a mesma versào), tendo seu keerelrecompilado para habilitar o protocolo IPv6.

I contiguraça da máquina servidora IVlsiteborise encontra-se descrita a seguir:

\section{Hardware:}

- 2 microprocessadores PII $350 \mathrm{Ml} \mathrm{I} /$;

- $256 \mathrm{MB}$ de momória RAM;

- 2 discos SCSI QLANTUM de 8 GB, com 2 partiçós de 4 GiB cada um;

- Placa l'ast lithernet Genius Glio0'1XRII 10/100Mbps, chipset Realtek 8139;

- Placa NTM Fore PCA200E: 155Mbps.

\section{Sistemas Operacionais:}

- Windows N1 4.0;

- Linux Red Hat 6.2 (com kernel 2.4.0-teste11). 


\section{Configurações de Rede (Interface Fast Ethernet):}

- IPv4: 143.107.231.195, Mask: 255.255.255.224;

- LPvo: fect0:0:0:1::10/64.

I miquina cliente /ame/foi configurada da seguinte maneira:

\section{Hardware:}

- 1 microprocessador P'entium PRO-S $200 \mathrm{MHz}$;

- 96 MB de memória RAM;

- 1 disco IDE QUANTUM SIROCCO1700A de 1.6 GB;

- I disco IDIE NEC DSE1700A de 1.4 GB;

- Placa l'ast Lithernet Genius GF1001'XRII 10/100Mbps;

- Placa N'TM fore PCA2001: 155Mbps.

\section{Sistema Operacional:}

- I.inux Red Hat 6.2(com kernel 2.4.0-teste11).

\section{Configurações de Rede (Interface Ethernet):}

- IPv4: 143.107.231.196, Mask: 255.255.255.224;

- HPv6: feco:0:0:1::11/64

I máquina clicnte Camptari foi configurada do seguinte modo:

\section{Hardware:}

- 1 microprocessador Pentium $166 \mathrm{MHz}$;

- 6+ MB de memória RAM;

- I disco IDL QUANTUM Fireball de 4GB;

- Placa fast Lethernet Genius Gl100 LXRII 10/100Mbps;

- Placa Al'M Fore PCA2001: 155Mbps.

\section{Sistema Operacional:}

- Linux Red Hat 6.2 (com kcrncl 2.4.0-teste11).

\section{Configurações de Rede (Interface Ethetnet):}

- IPvt: 143.107.231.197, Mask: 255.255.255.224;

- HPv: fect:0:0:1:12/64. 


\section{3 - Aplicação Cliente/Servidor com RTP}

I primeira aplicação desenvolvida utilizou recursos da $\Lambda$ PJ JMl; tanto para a implementação do scrvictor quanto do clicnte. No Capítulo 4, no tópico 4.4 - API JMF (Java Media Framework), foi mostrado como ć feita a aquisiçào de quadros individuais com um Processır do INIF (processador). A implementaçào do servidor com RTP utiliza o Processordescrito até o passo 5. crando $\mathrm{cm}$ seguida uma saida de dados e iniciando a transmissảo. Os passos para a implenentaçào do servidor se cncontram a seguir:

1. Cria-se um DataSolire (o arcuivo do vídeo a ser processado);

2. Cria-sc um Processor (baseado no DataSource);

3. Coloca-se o Processor no estado Configurado;

t. Obtém-se o controle das tracker do vídeo;

5. Determina-se qual tipo de video será utilizado;

6. Coloca-se o Processor no cstado Realizando;

7. Cria-sc um Data.Sink (um sockêt de saida de dados, com o endereço da máquina servidora c a porta pela qual será efetuada a transmissào);

8. Configura-se o Processor com a Datasinte.

1). Coloca-se o Proctstor no estado Inicializado, c a transmissão tem início.

1 implementaçào do cliente é mais simplificada, c utiliza um Playerque, em termos arquiteturais, se assemclha a um Processor do JMF. A arquitetura do Player.JMF, é mostrada na Figura 5-2.

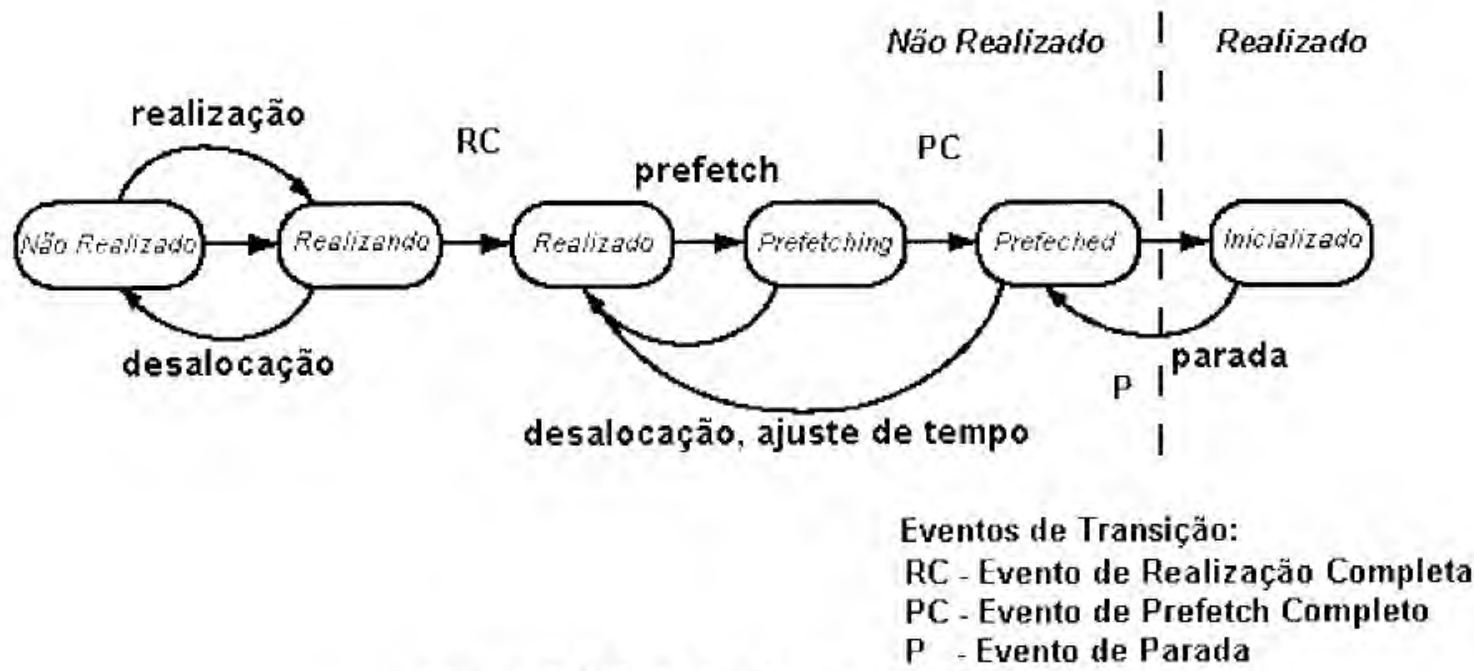

Figura 5-2: Estados de um Player JMF 
Para a implementaçào do cliente, os seguintes passos foram scguidos:

1. Cria-se um Medial tocator (um socket de recepçào de dados, com endereço da máquina scrvidora c porta pela qual cla cstá transmitindo);

2. Cria-se um Player (bascado no Medial ocator);

3. Coloca-sc o Player no estado Realizado, c quando dados começarcm a ser reccbidos pelo Mediul_acutor; a recepção tem ínicio.

lista aplicaçà se mostrou capaz de transmitir vídeos descomprimidos e comprimidos com os formans Qlicketime, JPFG, MPEG-2, H261 e II263, scndo que alguns arquivos tiveram de ser converridos para realizar a transmissão (os processadores do JMF, dependendo do sistema operacional - Linux e Windows, nào conseguiam criar um processador capa de iniciar a Iransmissào. $\Lambda$ Figura 5-3 mostra a tela do cliente, em uma transmissào JPEG.

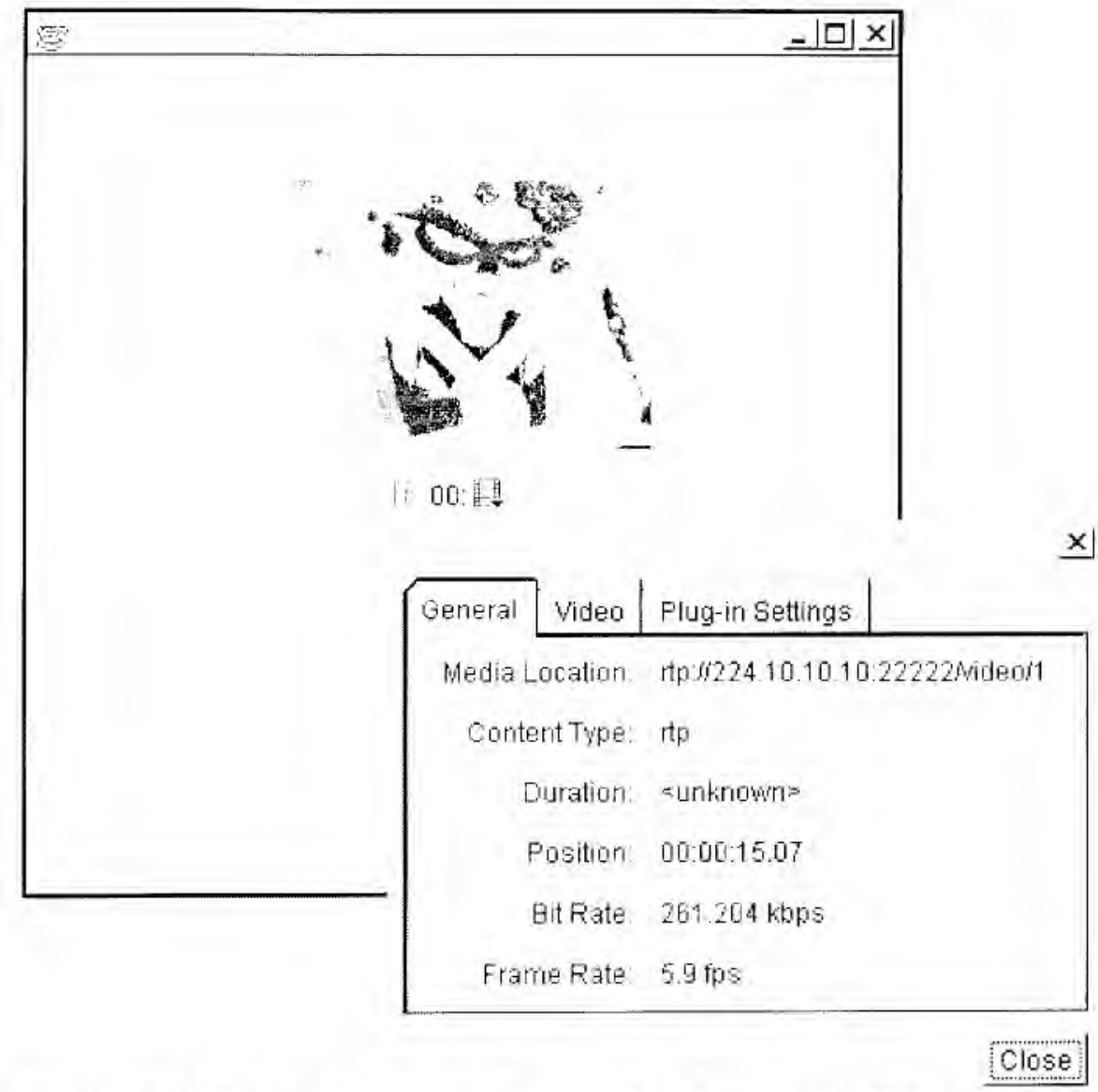

Figura 5-3: Tela da Aplicação Cliente Recebendo um Vídeo por RTP 
Ipesar de vários testes terem sido cfetuados com sucesso, partindo de servidores e clientes com 1) mesmo sistema operacional e em sistemas diferentes, a implementação do R'l'P bascada em IPvt thio pocke ser adaptada ao protocolo IPv6, sendo necessário a implementaçào de outra aplicacio, mostrada no próximo tópico.

\section{4 - A Aplicação Cliente/Servidor IPv4/IPv6}

\subsection{1 - Visão Geral da Aplicação}

I transmissão dos quadros com sackets $\Pi \mathrm{P} 4 / / \mathrm{Pv} 6$ foi descnvolvida em conjunto com outro pesquisador, l,uciano Martins (Martins, 2001). Uma visào geral da aplicaçào scrá apresentada, mostrando suas funcionalidades atuais.

Vo memento que o código é compilado, deve scr cscolhido o compilador (jana para IPv4 ou jïpsy Pára IPV(6) c a porta pela qual a transmissào scrá efctuada ou recebida. Durante a execuçào do servidor, nào ć possivel realizar a troca de protocolo e nem a troca da porta de comunicaçào. A rela dá aplicação do cliente é mostrada na Figura 5-4.

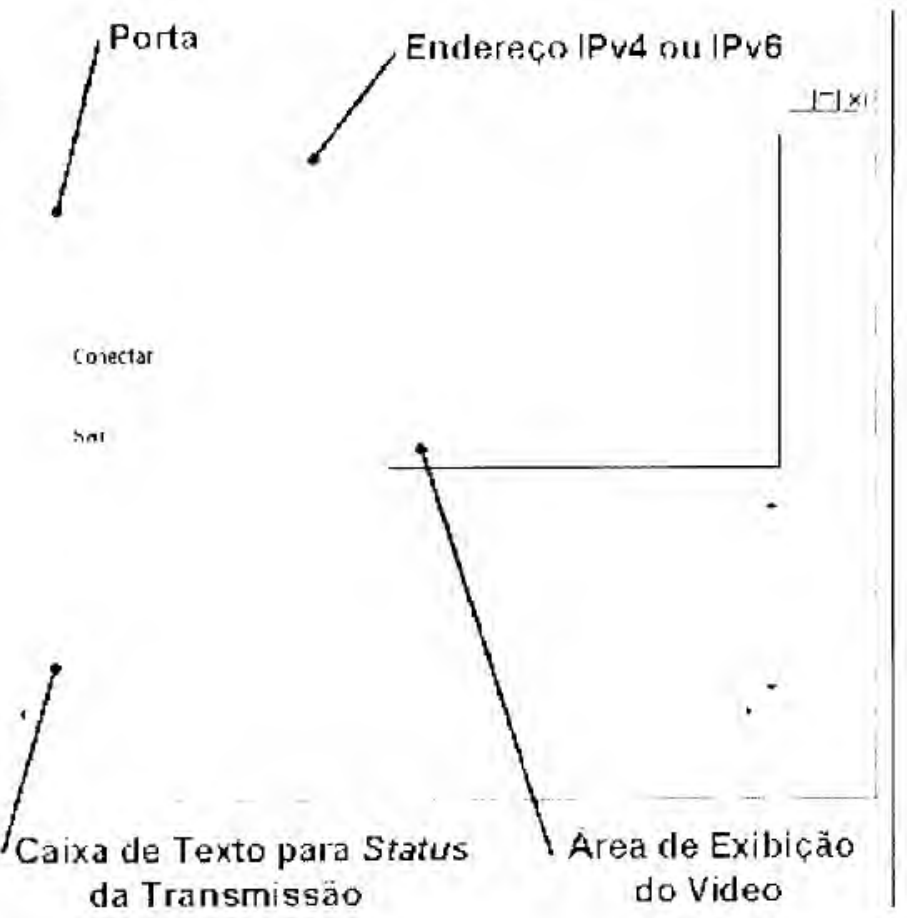

Figura 5-4: Tela do Cliente da Aplicação com Suporte IPv4/IPv6 
Liscollido o protocolo e compilado o código do scrvidor, este último passa a ser interpretado pcla miquma virtual Java. Determina-se, entào, a porta de escuta com a qual o sockét do cliente irá se comunicar e o tamanho máximo do pacote a sor transmitido. Liscolhidos os parâmetros, o servider é inicializado, e passa a escutar a rede até que um cliente notifique que está apto a recebrer um vídeo.

Da mesma forma yuc o protocolo é escolhido no servidor, deve ser realizada a escolha no cliente tamberm, quando o código é compilado. Ao ser iniciado, o cliente deve informar o endereço If de servider e a porta de envio de sinal.

(Quando o servidor recebe a comunicaçào do cliente (através de um socket TCP), ele cria uma thread de controle especifica para aquele clicnte. O thread de controle envia uma lista de vídeos disponiseds ao cliente, para que ele escolha qual vídeo quer receber. Além do nome do vídeo, tambim consta da lista o stutur de transmissào ("nào exccutando" c "exccutando"). Numa siruacio inicial, o servidor irá possuir vídcos apenas no staturs "nào executando".

() clicutc envia seu pedido à thread de controle do servidor; se o vídeo nào estiver sendo (xecutato no momento, o servidor cria uma thread geradora de quadros individuais (que utiliza o controle implementado com JMI') e uma thread emissora, que passa a transmitir o vídec por um endereco multicast específico. Como o endereço é de multicasting, apenas pacotes CDP sào transmitidos, o que gerou uma série de problemas discutidos na seçào $\mathbf{5 . 4 . 3}$ Problemáticas no Envio e Recebimento dos Datagramas. Ao mesmo tempo que o servidor cria sua flyrad emissora, o clicnic cria uma thread receptora, que passa a receber os pacotes (II)P e a cxibir o vídeo.

Sc ourro clicnte realizar um pedido de um vídeo que já estiver sendo executado, ele também deve criar sua thrad receptora, mas passa a receber os pacotes vídeo de uma thread emissora do servider, criada previamente. Assim que a thread emissora terminar de exibir o vídco, cla destruirá sua /linad emissoral. Os clientes também destroem sua flirud receptora assim que terminam de exibir seus vídeos. A Figura 5-5 mostra o esquema das flireads de um servidor, transmitindo o mesmo rideo a dois clicntes. Vale ressaltar que o "cliente 2" começa a receber imagens do 
momento corrente do vídeo que estiver sendo transmitido para o "clicnte 1" (multicasting), e nào imagens do inicio do vídco.

\section{Servidor}

escuta

controle

controle

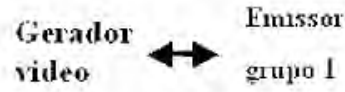

conecta

Receptol

Fileo

conecta

Receptor

Vindea

Cliente 1

Cliente 2

Figura 5-5: Threads do Servidor e de dois Clientes Recebendo o Mesmo Vídeo

\subsection{2 - Thread Gerador de Quadros}

I thread geradora de quadros utiliza a API JMF para converter os tipos de vídeo mais conhecidos em uma seqüência de imagens. Posteriormente, essas imagens sào transformadas em 3 (trés) matrizes numéricas na representaçăo RGB (Red, Gimen, Blue). Apesar do modelo de cores de innagens da linguagem lava utilizar a representaçào $A R(B B(A-A / p / s a)$, que pode determinar mansparência, apenas os três canais de cores são utilizados.

Cada uma das matrizes, necessita de 1 byte para representar cada pixel. $\Lambda$ ssim, sào 24 bits para cadá prixel. I representaçào em memória é um arư do upo int, como mostra a Figura 5-6 


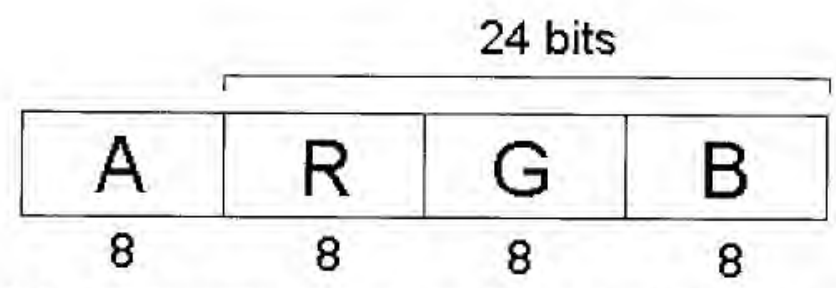

Figura 5-6: Representação em bits de um int da Liguaguem Java

l'ara transmitir os dados, cada canal foi separado $\mathrm{cm}$ um aroy do tipo lyte (representação de 8 bits). Contudo, em geral, um quadro do vídeo descomprimido é muito grande para ser transmitido em apenas um datagrama. Como exemplo, um vídeo que tenha resoluçào por quadro de $2+1 \mathrm{x}$ 160 pixcls, tem no total $112,5 \mathrm{~Kb}$. Se forem utilizados pacotes de $48 \mathrm{~Kb}$, scrào necessirios 3 (trés) datagramas. Recalculando o tamanho de cada datagrama, dividi-se 112,5 por 3, o que resultaria em datagramas de $37,5 \mathrm{~Kb}$.

()s scyuintes cálculos foram usados para a divisào de um quadro para gerar datagramas com polyloulde tamanhos iguais a serem transmitidos:

\section{Largura x Altura x Bytes_por_pixel (3)}

$\frac{\text { Tamanho Máximo do Payload }}{\text { Largura x Altura x Bytes_por_pixel (3) }}$
$\frac{\text { Número de Divisões }}{\text { Número de Divisões }}$

\subsection{3 - Problemáticas no Envio e Recebimento dos Datagramas}

Para minimizar o processamento do servidor no envio dos pacotes que compòe um quadro, um pré-processamento foi programado. Foi elaborado um arquivo (de extensào ".11") contendo os quadron descompactados $\mathrm{e}$ divididos.

Vlém de conter os quadros divididos, antes dos dados de cada datagrama foram colocadas duas informaçós adicionais: o número do quadro ( $\mathrm{fr}$ e e o número do datagrama transmitido (pc), ambos de 4 bytes. 
Fistes dois dados auxiliaram na reconstruçào dos quadros para cxibiçào, pois os sockets multicast traballiam com o protocolo UDP. Utilizando este protocolo, existe o risco de pacotes se perderem ou chegarem fora de ordem, sem que o servidor tenha conhecimento do ocorrido. A

Figura 5-7 mostra um quadro reconstruido corretamente e um quadro reconstruído com pacotes firra de ordem.

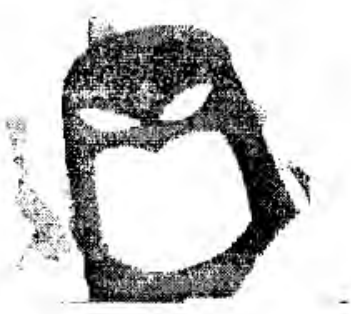

Pacotes em Ordem Normal

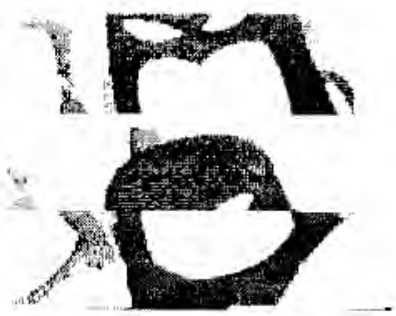

Pacotes Desordenados

Figura 5-7: Quadros Remontados com Pacotes UDP

Mesmu minimizando o tempo de transmissão dos pacotes, o processo do servidor que envia os quadros tcm outros problemas para ser exccutado cm tempo real:

- () primeiro deles está no tempo de acesso ao dispositivo de armazcnamento onde se cheontra o arquivo ".ll", scja cle em disco ou memória, c no posterior processamento para cnvio dos pacotes através do socket UDP;

- O segundo, está relacionado ao tempo no qual o vídeo foi elaborado, que deve ser mantido no cliente.

1: importante ressaltar que esse controle de tempo é feito exclusivamente pelo servidor.

Como o envio dos pacotes se encontra dentro de um loop, após realizar a leitura do pacote a ser transmitido e encaminhá-lo ao sockett, é feito um cálculo, que indicará se o loop precisa ser efetuado com menor velocidade, mais rapidamente ou está sendo realizado no tempo ideal.

I limguagem lava, utilizada para claboraçào do software, é interpretada por máquinas virtuais. As máquitns virtuais (das versòes jdk1.2.2 c jdk1.3) pata Windows (98/NT), apresentam desempenhos muito melhores que as máquinas virtuais para Linux (Red Hat 6.2). Nas transmussòcs efetuadas, os dois casos de ajuste de tempo (de espera dentro do loop de transmissào ou de aranço dos yuadros para envio) foram cncontrados, devido a diferença de desempenho das máguttas virtuats. 
Para realizar o cálculo, é necessátio saber o tempo de geraçào do vídeo e o núme ro total de quadres a serem exibidos. Dividindo o tempo de geraçào (em segundos) pelo total de quadros, (1) tén-se o número de quadros por segundo de exibiçào do vídeo, como é mostrado a seguir:

\section{Tempo total do Vídeo (em segundos) \\ Total de Quadros}

Sabende, quantos quadros podem ser exibidos em um segundo, pode-se também calcular se haveri cspera no loop ou avanço nos quadros:

1000

Número de Divisões x Quadros por segundo

- Processamento (ms)* = Tempo de Ajuste (ms)

to tempo de Processamento ( $\mathrm{cm}$ milisscgundos) indica o tempo de acesso ao dispositivo de :rmaznamento do vídco somado ao tempo de processamento para transmissão através do socket. Tísece ecmpo varia no decorrer da execuçào, sendo necessário ser medido dentro do processo.

Se o 7 empo de Ajuste for maior ou igual a zero, indica que esse será o tempo necessário (em milisscyundos) de espera para execuçào do próximo loop. Caso o tempo seja menor do que zero, $\dot{c}$ necessiria a realizaçào de um novo cálculo, para saber quantos pacotes o servidor terá que "pular" pata ajustar o tempo de cxibiçào:

\section{Tempo de Ajuste (ms) x Número de Divisões x Quadros por segundo}

= Número de Pacotes a serem "pulados" 1000

C:Lș " Número de Pacotes a screm "pulados" nào for um númeto inteiro, ele deve ser arredondado para cima.

Considerando que o controle de tempo é feito no scrvidor, o lado do cliente tem apcnas que renentar o quadro e exibi-lo. Assim que um datagrama é recebido pelo sacket do cliente, é identificado a qual quadro cle pertence e o scu número. Enquanto o cliente receber datagramas com fragmentos do mesmo quadro, ele armazena esses dados para futura exibição, mas sc 
receber um fragmento de um quadro posterior, cle descarta todos os fragmentos do quadro anterior e começa a reconstruçào do novo quadro.

\section{5 - Compactação de Vídeo}

Is máyuinas virtuais Java para Windows apresentam um melhor desempenho se comparadas às máquinas virtuais para linux, sendo que o mesmo código apresentou rendimento diferente nos dols sistemas operacionais, Algumas medidas de tempo para exemplificar a diferença de descmpenho scrào apresentadas no tópico 5.5.6 - Desempenho da Compactação Daub4 -

LZW nas MV Java em Linux e Windows. Por esses motivos, as medidas de tempo, aprescntadas a seguir, foram realizadas em uma máquina operando com o sistema operacional Windenvs N1 to (máquina servidora - W/hitehorse). Para os testes, a imagem padrào utilizada foi "lentritigif".

Como um arquivo proprictário cstava scndo pré-processado para minimizar o processamento do scrvidor, isto também poderia ser feito com a compactaçào, possibilitando a utilização de algorimos assimétricos. Com essa arquitetura, o problema de exibiçào do vídeo no mesmo kmpe em que foi gerado passa para o cliente, pois o tempo de processamento para descompactar os streans pode variar conforme a capacidade das máquinas clientes.

\subsection{1 - Compactação JPEG}

() princiro método analisado foi a compactaçào JPLG, através de codificadorcs c decodificadores em Java, implementados pela Sun Micrasystoms. Joram utilizadas imagens estáticas de tam,uhe diferente $(128 \times 128$ pkets $=48 \mathrm{~Kb}, 256 \times 256$ pive/s $=192 \mathrm{~Kb}$ c $512 \times 512$ pixe $/ \mathrm{s}=$ $768 \mathrm{~K}$ ) e com diferentes graus de compactaçăo. Quanto maior a porcentagem de compactação (que reflete diretamente na economia da largura de banda utilizada na transmissào), maior foi o cimpo necessário para realizar a descompactaçào. Os dados sào mostrados na Tabela 5-1 e nas Figuras 5-8 - 5-9.

\footnotetext{
'A imagem referida é padrão da LEEE obtida cm 3 resoluçōes $(128 \times 128,256 \times 256$ e $512 \times 512)$
} 
Tabela 5-1: Dados da Compactação JPEG com codificadores da Sun Microsystem

\begin{tabular}{|c|c|c|c|c|}
\hline $\begin{array}{c}\text { Resolução } \\
\text { da } \\
\text { Imagem } \\
\text { (pixcls) }\end{array}$ & $\begin{array}{c}\text { Tamanho do } \\
\text { Arquivo } \\
\text { Descomprimido } \\
\text { (Kb) }\end{array}$ & $\begin{array}{c}\text { Tam. do Arquivo } \\
\text { Comprimido com 75\% } \\
\text { de qualidade (Kb) }\end{array}$ & $\begin{array}{c}\text { Tam. do Arquivo } \\
\text { Comprimido com } \\
\mathbf{9 0 \%} \text { de qualidade } \\
\text { (Kb) }\end{array}$ & $\begin{array}{c}\text { Tempo de } \\
\text { Descompressão } \\
\text { (ms) }\end{array}$ \\
\hline $128 \times 128$ & 48 & 9 & 6 & 100 \\
\hline $256 \times 256$ & 192 & 41 & 25 & 360 \\
\hline $512 \times 512$ & 768 & 78 & 47 & 1460 \\
\hline
\end{tabular}

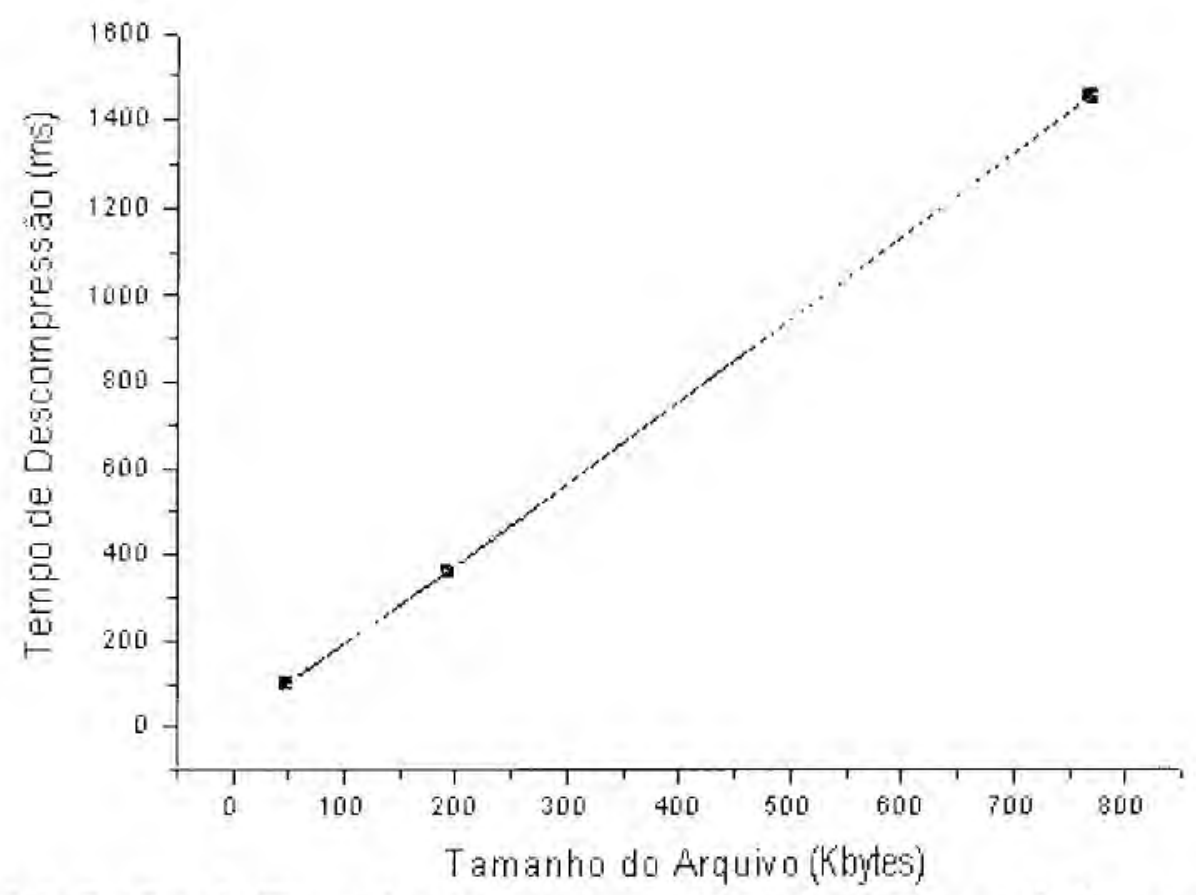

Figura 5-8: Gráfico do Tamanho do Arquivo em Relação ao Tempo de Descompressão 


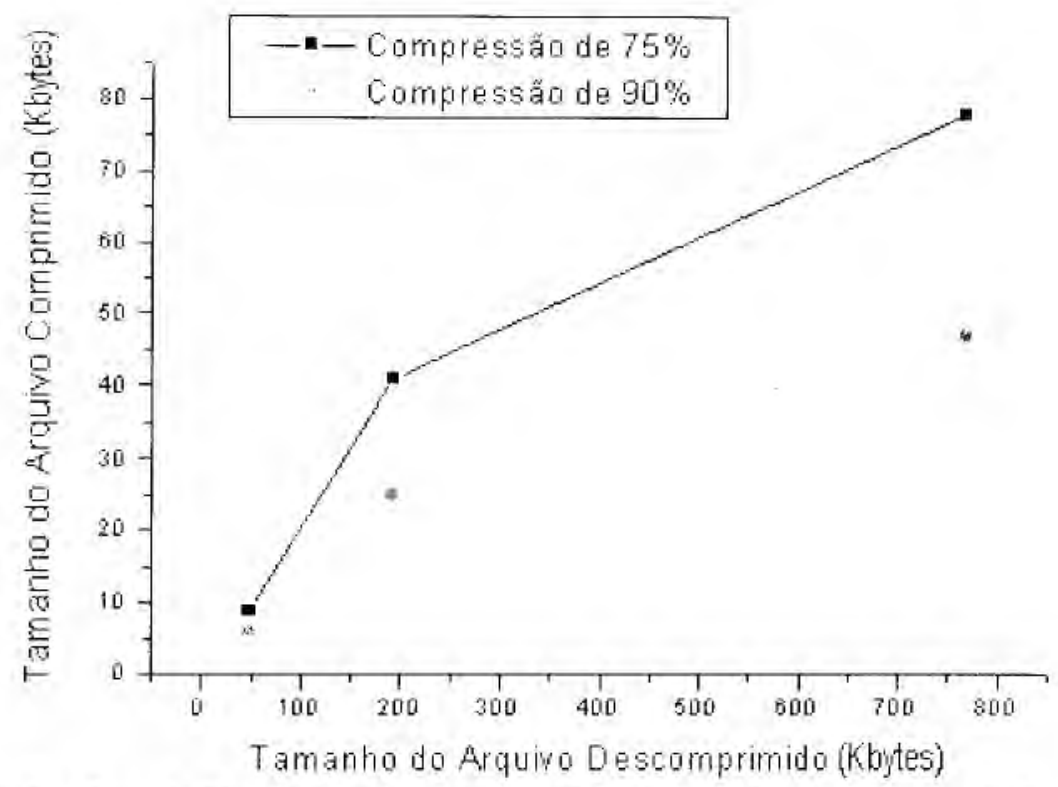

Figura 5-9: Gráfico de Tamanho do Arquivo Descomprimido em Relação ao Arquivo
Comprimido

Iim relaçào ao espaço de armazenamento a ao ganho de largura de banda, os dados mostram um significative ganho utilizando compactação. Como exemplo, uma imagem de 256 × 256 paxe/s, que pessui $192 \mathrm{~Kb}$, ao ser compactada com $75 \%$ de qualidade obteve $86 \%$ de compactaçào (o lamanhes da imagem compactada foi de $25 \mathrm{~Kb}$ ). Para outra imagem de $512 \times 512$ pixelis, que possuiu $768 \mathrm{~Kb}$, ao ser compactada com $90 \%$ de qualidade obteve 94 de compactaçào (o tamanho da imagem compactada foi de $47 \mathrm{~Kb}$ ).

Inalisindo a curva mostrada na Figura 5-3, notn-se um comportamento linear $(Y=\Lambda * X+1$, onde $1=1,89$ e $B=3,33)$. Assim, uma imagem de $640 \times 480$ pixels, que ocupa $900 \mathrm{~Kb}$, demoraria aproximadamente $1705 \mathrm{~ms}$ para ser descomprimida. Esse tempo impossibilita que o vídeo pussa exibido a uma taxa de 1 quadro por segundo, mesmo vídeos de baixa resoluçào, onde um quadro descompactado nà̃o ocupe mais de $200 \mathrm{~Kb}$ (como na resoluçào $240 \times 160$ ). Um vídeo para ser exibido $\mathrm{cm}$ tempo real nào poderia apresentar uma taxa de apresentaçào de mais de 3 quadros por segundo, o que implica em uma qualidade muito baixa.

Gomo a processo de compactaçào JPEG foi efetuado com codificadores e decoficadores, de cujos códigos nảo permitia uma análise de desempenho para avaliar em qual ctapa da compactaçâdescompactaçào o tempo de processamentos seria crítico, um método de comprectaças proprictáno foi analisado. 


\subsection{2 - Implementação da Transformada Wavelet Daub4}

Inicialmente, foi desenvolvido um software que lê uma imagem (de dimensòes $256 \times 256$ prixe/s), realiza a transformada, executa sua inversa e grava os dados em um arquivo texto. Esse softwarc toj claborado para que fossem feitas medidas de tempo de execuçào da transformada. Essc dado foi utilizado para comparaçào no trabalho Arquiteturas para Compressão de Vídeo Baseado em Sistemas Reconfiguráveis (Soto, 2000). Contudo, obscrvar a imagem formada pelo) processo das transformadas nào era possível, c cntào foi claborado outro software, para visualizaçào, que lề o arquivo texto e exibc a imagem correspondente.

Come os interesse for o de utilizar a Daub4 para compactar imagens, o programa inicial foi modifieado para que medidas de compactaçào fosscm efetuadas. Para realizar a compactaçào da matri\% da imagem, basta tornar alguns dos elementos da matriz da transformada (uma matri\% de mesma dimensào da imagem original - 256 × 256 na implementaçào) e "zerar" alguns de seus clementos. Assim, é possível através de algum dos métodos de codificaçào (como L/AW, Huffrman, entre outros) diminuir o tamanho do arquivo a ser gravado, visto que boa parte dos números da matriz teria o valor zero.

(Zuandis a transformada inversa é cfetuada sobre a matriz que teve alguns de seus elementos "zcrados", cla se apresenta com dados proporcionalmente diferentes ao número de elementos yue firam "zerados", sendo esse método considerado com perda (/ossy); para calcular essa perda, uim calculo entre a os elementos da matriz original, chamada de $\Lambda$, e da matriz final, chamada de 13, for cfetuado. Foi cscolhido o método Root Mean Symare (RMSF), que ć definido como a raiz quadrada da somatória do quadrado da diferença cntre os elementos da matriz original, como ilustra a formula a seguir.

$$
\text { RMSE }=\sqrt{\sum\left(a_{i j}-b_{i j}\right)^{2}}
$$

Com o cálculo do RMSE, foi possível verificar qual o número máximo de elcmentos da matriz da Iransformada que pudessem ser "zcrados" sem que nenhuma perda fosse visualmente notada.

Iof descnvolvido um método para "\%crar" os elcmentos da matriz transformada, bascado cm uma escala logarítmica, cujo algoritmo é mostrado a seguir:

- Inicialmente, definc-se que existe uma cscala; 
- Verifica-se qual o valor máximo obtido na matriz da transformada;

- Divide-se esse valor por 2 e verifica-se se esse valor é maior que 2; se nào for, o valor da escala è incrementado; se for, encerra-se o processo.

Nor final do processo, tem-se valores para cada uma das escalas e, de acordo com o número de escalas a screm "\%cradas", todos os valores acima daquela cscala sào "\%erados".

l'ara exemplificar o processo, é apresentada, a seguir, sua funcionalidade em uma imagem de testes do H1:1: conforme ilustra a Figura 5-10.

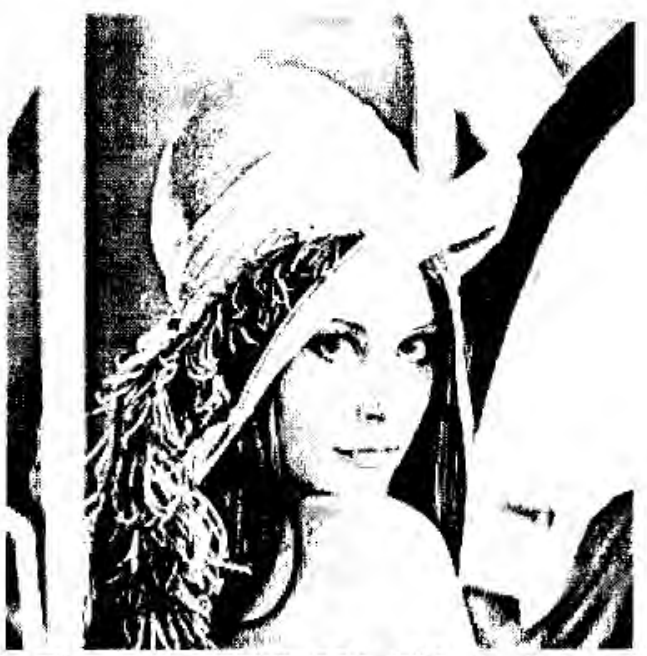

Figura 5-10: Imagem de Teste do IEEE, 256x256 pixels em 256 Escalas de Cinza (lenna.gif)

()s dados do arquivo da imagem sào os seguintes:

- Nome do Arquivo: lenna.gif

- Tamanho do arquive (cm pixcls): $256 \times 256=65536$ pixcls

- Tipo de arquivo: 8 bits (grayscale - 256 tons de cinza)

Ipós a transformada wavelet Daub4 ser efctuada, obteve-se os seguintes dados:

- Máximo absoluto: 13899.778

- Numero de Escalas: 14

( Tabela 5-2 mostra os dados obtidos, "zerando" 9 escalas, sendo:

- Escala: número de escalas "zeradas"; 
maiores do que 7 , geralmente quando o processo de "zerar" elementos da matriz transformada ultrapassa a quinta escala. A Figura 5-12 ilustra esse caso.

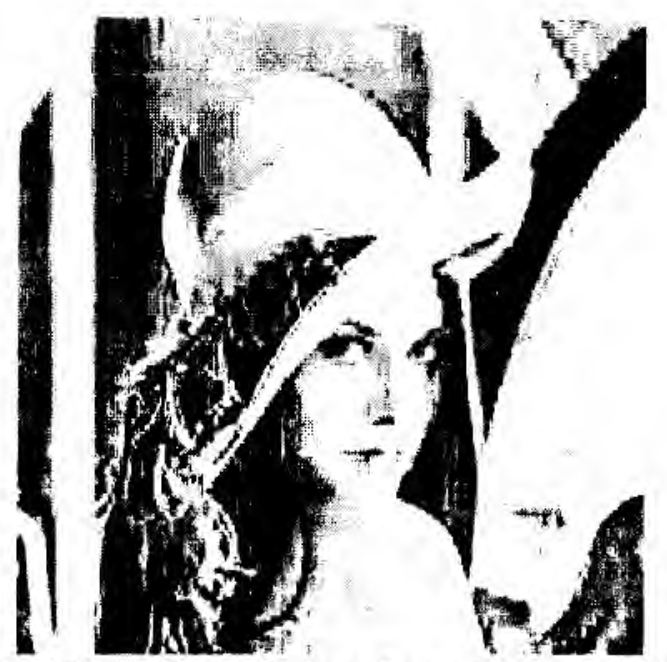

Figura 5-12: Imagem Obtida na Transformação wavelet, com 96,39\% de Compressão Relativa e RMSE 10,76

\subsection{3 - Medidas de Tempo da Daub4 em Imagens em Escalas de Cinza e Coloridas}

Ipós implementar as transformadas suavelets Daub4, o próximo passo foi a implementação de um software capaz de cfetuar medidas de tempo das transformadas. As classes da transformada foram implementadas para processar matrizes de ponto flutuante (tipo /loat na linguagem Java, yue ocupam 32 (bits).

Para tentar minimizar o tempo de processamento, uma nova implementaçào foi feita, utilizando matries de números inteiros, (tipo int na linguagem Java) ao invés de matrizes de pontos Hlutuante. Para essa modificaçào, os coeficientes da Daubt foram transformados cm números incures (comose fosscm multiplicados por $2^{5}=32$ ) c uma ctapa adicional for implementada, para realiyar a normalizaçào da matriz final (devido à multiplicaçào feita para adequaçào dos coeficientes da transformada). Os indices modificados se encontram na Tabela 5-3.

Tabela 5-3: Coeficientes da Daub4 representados em Ponto Flutuante e Inteiros

\begin{tabular}{|c|c|c|}
\hline Coeficiente & Valor Ponto Flutuante & Valor Inteiro \\
\hline$c_{01}$ & 0.482962 & 11 \\
\hline$c_{1}$ & 0.8365163 & 2 \\
\hline$c_{2}$ & 0.2241438 & 5 \\
\hline$c_{3}$ & -0.1294095 & -3 \\
\hline
\end{tabular}


- Valor de corte: valor utilizado para "zerar" os clementos da matriz transformada;

- Elementos "zerados": número de elementos que passaram a assumir o valor zero;

- Compressão relativa: razào entre o número de elcmentos "zerados" e o total de dementos da matriz;

- RMSE: valor do cálculo do RMSLE obtido.

Tabela 5-2: Valores Obtidos no Processamento da Imagem (lenna.gif)

\begin{tabular}{|c|c|c|c|c|}
\hline Escala & Valor de corte & $\begin{array}{c}\text { Elementos } \\
\text { Zerados }\end{array}$ & $\begin{array}{c}\text { Compressão } \\
\text { Relativa }\end{array}$ & RMSE \\
\hline 1 & 1.70 & 23294 & $35.54 \%$ & 0.56 \\
\hline 2 & 3.39 & 36845 & $56.22 \%$ & 1.26 \\
\hline 3 & 6.79 & 47566 & $72.58 \%$ & 2.34 \\
\hline 4 & 13.57 & 55045 & $83.99 \%$ & 4.07 \\
\hline 5 & 27.15 & 60154 & $91.79 \%$ & 6.81 \\
\hline 6 & 54.30 & 63172 & $96.39 \%$ & 10.76 \\
\hline 7 & 108.59 & 64640 & $98.63 \%$ & 15.61 \\
\hline 8 & 217.18 & 65172 & $99.44 \%$ & 20.64 \\
\hline 9 & 434.37 & 65409 & $99.80 \%$ & 27.34 \\
\hline
\end{tabular}

()bservande as imagens resultantes desse processo, nota-se que até o corte de escala 5 (RMSE = 6,81), naio existem perdas visuais muito significativas, como é mostrado na figura 5-11.

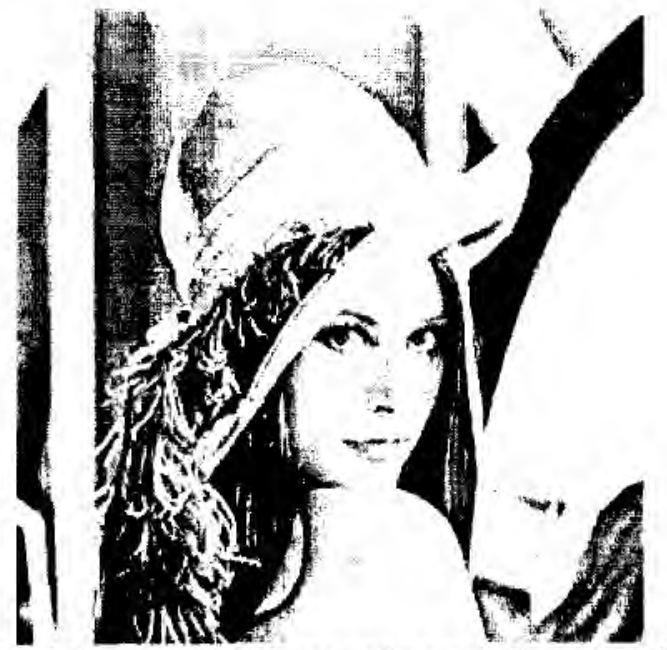

Figura 5-11: Imagem Obtida na Transformação wavelet, com 91,79\% de Compressão Relativa e RMSE 6,81

A primeira conclusão se refere ao valor ideal do RMSE; analisando os testes efetuados nesse arquivo e em outros, observotr-se que as perdas começam a ser notadas para valores do RMSE 
Outra implementaçào adicional foi feita para processar tanto imagens em escalas de cinza como imagens coloridas. Para processar imagens em escalas de cinza, a transformada cra aplicada em apenits uma matrik numérica, mas em imagens coloridas foi necessário aplicar a transformada em trés maltri\%es numéricas.

lara processar imagens em escalas de cinza em Java, após a imagem ser lida, ela foi colocada no modele de imagem da linguagem, que consiste $\mathrm{cm}$ quatro matrizes numéricas tendo 8 bits para cada priel lisse modeles ARGB (Alplua Red Green Blue) já foi aprescntado no tópico 5.4.2 Thread Gerador de Quadros, na Figura 5-3.

() único canal nào utilizado foi o de transparência (Alpha). Contudo, uma média dos três canais restantes foi feita para a obtençào de apenas uma matriz numćrica, que represcntava a imagem com 8 liti por pixe/ Sc uma imagem em escalas de cinæa cra lida, os três canais RGB cram iguais e realizando a média cntec os três, cra obtida a mesma matrì de qualquer um dos canais. Contudo, se uma imagem colorida cra lida (possuindo os três canais RGB difcrentes), ao realizar a média e represchtar a imagem em apenas um canal, a nova matriz numérica representava a imagem colorida em escalas de cinza.

Para cfetuar o processamento de imagens coloridas, cada um dos três canais foi tratado de forma disrinta, e a transformada foi aplicada a cada um deles. Utilizando a imagem lenna.gif, com resoluçio de $256 \times 256$ pixels, algumas tomadas de tempo foram efetuadas para detcrminar o tempo das transformadas, com pontos flutuantes e inteiros, e em imagens $\mathrm{cm}$ escalas de cinza e coloridis. () dados se encontram na Tabela 5-4 e na Figura 5-13.

()bscrvando os dados, percebe-se que o tempo de exccuçào das transformadas que utilizavam matrizes de pontos flutuantes é menor do que as matrizes que cmpregavam inteiros. Realizando mediclas dentro do código, percebeu-se que o tempo para aplicar a transformada diminuiu. No (ntanı, o processo de normalizaçáo das matrizes obtidas acarretou um aumento no tempo total do precesso. 
Tabela 5-4: Medidas de Tempo da Daub4 para Imagens em Escalas de Cinza e Coloridas

\begin{tabular}{|c|c|c|c|}
\hline Tipo de Matriz(es) & Tipo da Imagen & $\begin{array}{c}\mathbf{N}^{\circ} \text { de Canais } \\
\text { (Matrizes) }\end{array}$ & $\begin{array}{c}\text { Tempo de Execução } \\
\text { (ms) }\end{array}$ \\
\hline Illt & Tscalas de Cinza & 1 & 297 \\
\hline Mlout & Fscalas de Cinza & 1 & 215 \\
\hline Iltt & Colorida & 3 & 735 \\
\hline lloat & Colorida & 3 & 532 \\
\hline
\end{tabular}

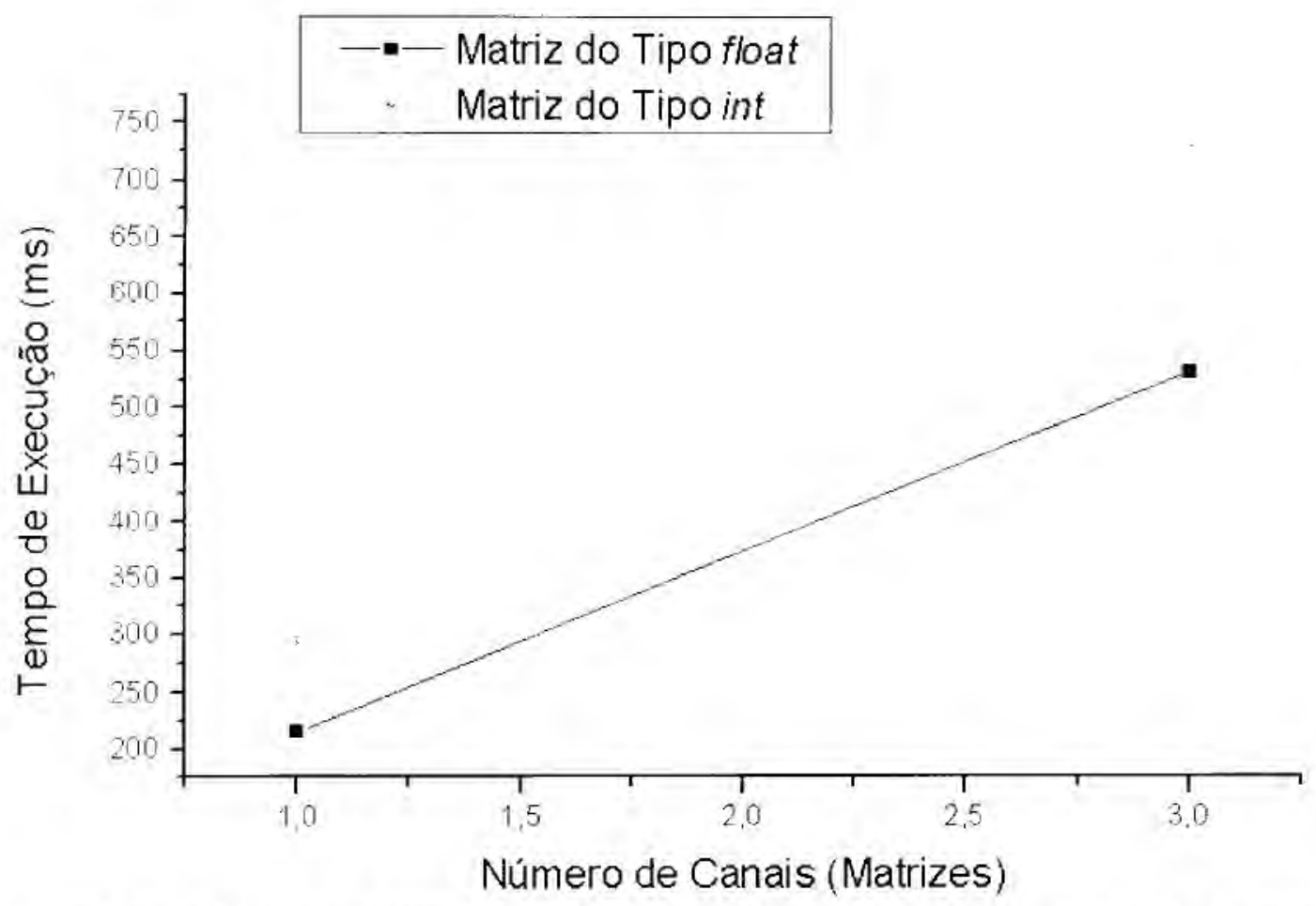

Figura 5-13: Gráfico do Número de Matrizes Processadas em Relação ao Tempo de Execução

\subsection{4- Compactação Daub4 - LZW}

() método de compactaçào proposto é composto dos seguintes passos:

1. Transformaçào da imagem em matrizes numćricas;

2. Iplicar a transformada Daub4 nas matrizes numćricas;

3. Jirnar alguns elementos das matrizes transformadas em zeros (isso implica em perda de dados e também no grau de compactaçào dos quadros);

4. Cindificar os dados resultantes com o algoritmo L\%W (nào ocorre perda de dados). 
Para reulizar a descompactaçào, o processo inverso é exccutado, onde o passo 3 nào é realizado. Para cala um dos 3 canais de dados (RGB), a transformada foi aplicada. $\Lambda$ codificaçào $L Z Z W$ foi aplicadi aos 3 canais como se fossem apenas um. Para todas as imagens processadas, o número de clencutos "zerados" foi escolhido com base no cálculo do RMSE.

Com o cálculo do RMSE, foi possivel verificar qual o númcro máximo de elementos da matriz da transformada que poderiam ser "zerados" sem que nenhuma perda visual fosse notada. A Tabela 5-5 e : Figura 5-14 mostram alguns dos dados obtidos:

Tabela 5-5: Dados da Descompactação com a Transformada Wavelet e Codificação LZW

\begin{tabular}{|c|c|c|c|c|}
\hline $\begin{array}{c}\text { Resolução da } \\
\text { Imagem (pixels) }\end{array}$ & $\begin{array}{c}\text { Tamanho do } \\
\text { Arquivo } \\
\text { Descomprimido(Kb) }\end{array}$ & $\begin{array}{c}\text { Tamanho do } \\
\text { Arquivo } \\
\text { Comprimido (Kb) }\end{array}$ & $\begin{array}{c}\text { Tempo da } \\
\text { Transformada } \\
\text { (ms) }\end{array}$ & $\begin{array}{c}\text { Tempo da } \\
\text { Codificação LZW } \\
\text { (ms) }\end{array}$ \\
\hline $128 \times 128$ & 48 & 9 & 250 & 263 \\
\hline $256 \times 256$ & 192 & 23 & 453 & 1563 \\
\hline $512 \times 512$ & 768 & 92 & 1094 & 5006 \\
\hline
\end{tabular}

Lpós a tomada de medidas, verificou-se que o tempo de execução da transformada inversa da compactaçào era inferior ao tempo necessário para a descompactaçào LZW, sendo esse algoritmo o responsável direto pelo baixo desempcnho da descompactaçào.

P'ara uma itnagem de $256 \times 256$ pixels, a transformada inversa dura cerca de $453 \mathrm{~ms}$, cnquanto a (xecucar da descompressio J I\% dura cerca de $1563 \mathrm{~ms}$. Se esse método fosse utilizado na transmusnáo de video, com a resoluçào proposta, nào seria possivel o vídeo ser cxibido a uma taxa de um yuadro por segundo. 


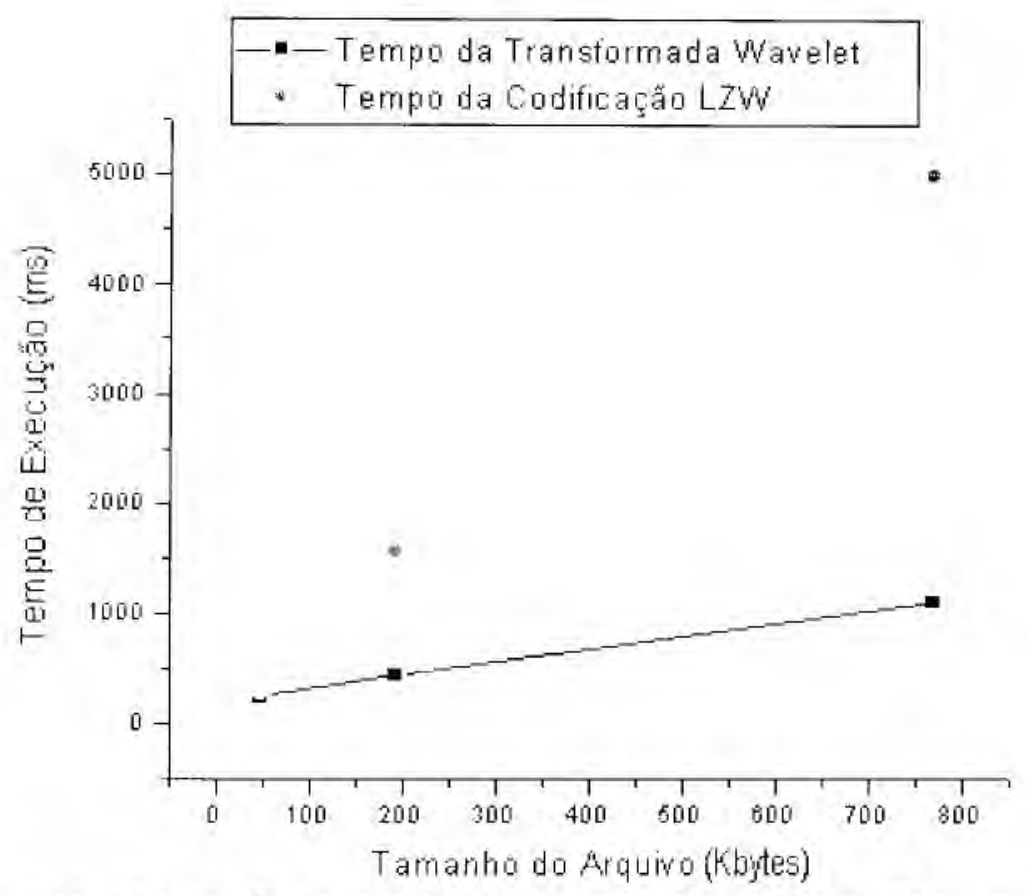

Figura 5-14: Gráfico do Tamanho do Arquivo em Relação aos Tempos de Execução

\subsection{5- Desempenho da Descompactação JPEG e Daub4 - LZW nas Máquinas Virtuais Java em Linux e Windows}

Io reilizar a descompressào JPLG, que utiliza os codificadores e decodificadores da Sum

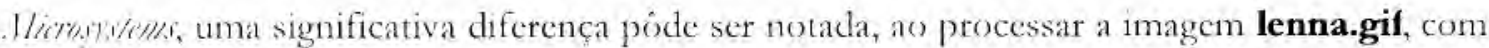
resolucite de $256 \times 256$ pixyli, como é apresentado na Tabela 5-6.

Tabela 5-6: Tempo de Execução da Descompactação JPEG em Windows e Linux

\begin{tabular}{|c|c|c|}
\hline Qualidade da Imagem & $\begin{array}{c}\text { Tempo de Execução no } \\
\text { Windows NT 4.0 (ms) }\end{array}$ & $\begin{array}{c}\text { Tempo de Execução no } \\
\text { Linux Red Heat 6.2 (ms) }\end{array}$ \\
\hline $75 \%$ & 515 & 636 \\
\hline $90 \%$ & 360 & 636 \\
\hline
\end{tabular}

() tempos mostraram maior diferença na descompactação utilizando o método proposto D)aub4 $-1 \%$, como é mostrado nas Tabelas 5-7 e 5-8. 
Tabela 5-7: Tempo de Execução da Descompactação Daub4-LZW no Windows NT 4.0

\begin{tabular}{|c|c|c|c|c|}
\hline $\begin{array}{c}\text { Tipo de } \\
\text { Transformada }\end{array}$ & $\begin{array}{c}\text { Número de } \\
\text { Canais } \\
\text { (Matrizes) }\end{array}$ & $\begin{array}{c}\text { Tempo de } \\
\text { Execução da } \\
\text { Daub4 (ms) }\end{array}$ & $\begin{array}{c}\text { Tempo de } \\
\text { Execução do } \\
\text { LZW (ms) }\end{array}$ & $\begin{array}{c}\text { Tempo de } \\
\text { Execução Total } \\
\text { (ms) }\end{array}$ \\
\hline int & 1 & 297 & 1109 & 1406 \\
\hline int & 3 & 532 & 1781 & 2313 \\
\hline /lout & 3 & 735 & 3890 & 4625 \\
\hline
\end{tabular}

Tabela 5-8: Tempo de Execução da Descompactação Daub4 - LZW no Linux Red Hat

\begin{tabular}{|c|c|c|c|c|}
\hline $\begin{array}{c}\text { Tipo de } \\
\text { Transformada }\end{array}$ & $\begin{array}{c}\text { Número de } \\
\text { Canais } \\
\text { (Matrizes) }\end{array}$ & $\begin{array}{c}\text { Tempo de } \\
\text { Execução da } \\
\text { Daub4 (ms) }\end{array}$ & $\begin{array}{c}\text { Tempo de } \\
\text { Execução do } \\
\text { LZW (ms) }\end{array}$ & $\begin{array}{c}\text { Tempo de } \\
\text { Execução Total } \\
\text { (ms) }\end{array}$ \\
\hline lilt & 1 & 1128 & 2528 & 3656 \\
\hline Float & 3 & 2664 & 7460 & 10124 \\
\hline lut & 3 & 3017 & 153337 & 18354 \\
\hline
\end{tabular}

\subsection{6 - Medidas de Tempo da Daub4 em Java e C++}

I linguagem Java é uma linguagem interpretada, e por isso alguns programas feitos em linguagens compiladas (como $\mathrm{C}++$ ), tendem a ter um desempenho melhor em tempo de execuçào, Como o melhor tempo com a linguagem Java foi o tempo no processamento de uma imagem em escalas de cirla com matrizes de ponto flutuante ( $215 \mathrm{~ms})$, isso permitiria que um vídeo de $256 \times 256$ prip/s forse exibido a una taxa máxima de 4 quadros por segundo. Como esse tempo se encontrava muito aquém do ideal, medidas de tempo de cxecuçào das transformadas manelets Daub + foram efetuadas na linguagem $\mathrm{C}++$ para verificar a diferença de desempenho.

foram implementadas, com certa facilidade, as transformadas que operam com matrizes de números inteiros $\mathrm{c}$ de pontos flutuantes, devido às semelhanças entre a linguagem Java c a linguagem $\mathrm{C}++$ (ambas orientadas a objetos). As medidas de tempo encontram-se na Tabela 59.

Tabela 5-9: Tempo de Execução de uma Transformada Wavelet Daub4 em Sistemas Operacionais Diferentes

\begin{tabular}{|c|c|c|}
\hline Tipo de Transformada & Linguagem & Tempo de Execução (ms) \\
\hline int & Java & 297 \\
\hline Hout & lava & 215 \\
\hline int & $\mathrm{C}++$ & 117 \\
\hline \%out & $\mathrm{C}++$ & 141 \\
\hline
\end{tabular}




\section{6 - Considerações Finais}

() principal objetivo do desenvolvimento das aplicaçòes desse trabalho foi o estudo da transmissào de quadros comprimidos de vídeo com técnicas de multicasting, c sua descompressào c exibiçào em tempo real, scndo necessários cálculos para a transmissão de quadros pelo servidor de vídeo, utilizando os protocolos IPv4 e IPv6 e medidas de tempo de processamento de descompressào de quadro individuais de vídeo.

No capitulo 7, serào abordadas as conclusóes sobre o trabalho aqui reportado, sobre os resultades obtidos, as contribuiçoes do trabalho e possíveis trabalhos futuros. 


\section{Conclusões e Trabalhos Futuros}

Com as novas tecnologias de redes, protocolos, técnicas de transmissào de dados e padròes de compressào, as transmissoes de vídeo tendem a scr tornar cada vez mais comuns. Como a cconomia da largura de banda é necessária para que a distribuição do vídeo seja cfetiva, são necessários estudos da problemática envolvida em aplicaçòcs cliente/servidor com suporte a multicurting e de padròes de compressòes.

Is tecricas de multricusting juntamente com o protocolo II'v6 em aplicaçòes desenvolvidas cm lava com o pacote Jipsy, possuem melhor desempenho quando comparadas ao mesmo cenário utilizando o protocolo IP'v4 (Martins, 2001). Aplicaçòes que utilizem tecnologias gratuitas e que possuam suporte a multitusting com $11 \mathrm{P}_{\mathrm{v}} 4 / 1 \mathrm{P}_{\mathrm{v}} 6$, trazcm novas perspectivas para a distribuição de video,

() palròes de compressào tendem a manter a qualidade do vídeo c aumentar a taxa de compressào de dados. As transformadas waveletstendem a substituir as transformadas de cossenos nos padròcs de compactaçào, como vêm ocorrendo atualmente em diversos padròes.

Is principais contribuiçós deste trabalho foram os cálculos apresentados para implementaçâo de aplicacoies cliente/servidor para transmissăo de video com suporte a multicasting $\mathrm{e}$ as medidas comparativas entrc os métodos de compressào MJPEG e com transformadas mavelets com codificaçà JiZW. Além disso, o desenvolvimento deste trabalho proporcionou diversos beneficiss tanto para o grupo InterMídia quanto para o ICMC - USP, quanto para pesquisadores c implementadores de tecnologias de rede e de aplicaçóes com vídeos. $\Lambda$ s pesquisas do grupo InterNlidia tèm como foco algumas tecnologias multimídias, $\mathrm{c}$ alguns trabalhos visam padrōes 
como MPLiG-4, MPEG-7 e MPEG-21. A implementaçào dos scrvidores de vídeo, descnvolvida neste trabalho, poderá scrvir como base para implementaçòes reais e testes, usando tais padròes.

Para implementadores e pesquisadores de tecnologias de rede, este trabalho proporciona um beneficio no que diz respeito aos estudos c testes realizados com o Linux, Java c Jipsy. Tais tecnologias sào distribuidas gratuitamente, o que facilita o desenvolvimento e pesquisa por diversias instituiçòes.

Isste trabalho infere sobre dois focos diferentes de pesquisa: transmissào c compressào de vídeo. Scnde assim, medidas e melhorias de eficiència nestes tópicos sào interessantes, visto que o desempenho de um sistema multimídia nào depende apenas de um dos focos separadamente, mas sim, da interaçăo entre esses dois focos.

I revisáo bibliográfica desta dissertaçào oferece referências importantes para todos que se interessem por esta árca. Além das contribuiçòcs citadas, outras propostas informais, porém intercssantes, surgiram no decorrer do desenvolvimento deste trabalho, e estào sendo avaliadas internamente ao grupo InterMídia.

\section{1 - Análise dos Resultados Obtidos e Propostas Para Trabalhos Futuros}

\subsection{1 - Aplicações Cliente/Servidor de Transmissão Multicasting de Vídeo}

1 aplicaçăo cliente/scrvidor com suportc IPv4/RTP, implementada inicialmente e baseada na IPI MIF, serviu como base de modelagem para a mplementaçào da outra aplicaçào (com suporte IPv $\left.+/ \mathrm{IP}_{\mathrm{v}} 6\right)$, além de trazer a tecnologia de controle de quadros individuais de um vídeo. Ipesat das tentativas de adequação desta aplicaçào ao protocolo IPv6 com Jipsy não apresentarem resultados satisfatórios, sigere-se que novos pacotes de suporte a IPv6 e à java sejam testados para a viabilizaçào de transmissòes IPv6 com a $\Lambda$ Pl JMF, em virtude dos recursos propercionados pela $A$ PI.

Iim relaçà à aplicação cliente/servidor com suporte a IPv4/IPvG, a implementaçào da thread transmissora de vídeo pode ser melhorada. Uma das melhorias pode ser feita no controle do rempu de exibiçào do video. $O$ controle apresentado determina o tempo de espera dentro do loop 
ou o número de pacotes a serem "pulados". Ao invés de controlar quantos pacotes seriam "pulados", o controle levaria cm consideraçào o quadro scndo exibido, permitindo que nào se transmita pacotes que nào serào remontados.

Para a implementaçào do cliente (sendo que os strumss sào compactados), é necessário que as máquinas virtuais Java apresentem desempenho ao menos similar ao das máquinas virtuais para Windows, ou que a linguagem seja substituída por outra de maior eficiência. Medidas feitas com a lingragem $\mathrm{C}++$, para exccuçaio das transformadas wavelets $\mathrm{cm}$ Jinux, apresentaram um desempenho superior em relaçào a linguagem Java. P'or esse motivo, a linguagem $\mathrm{C}++$ é sugerida para implementaçòes do cliente.

Uutro modo de melhorar o desempenho da aplicaçào, é a inclusào de um buffer no software cliente, permitindo que quadros possam ser acumulados para posterior exibição. Para sua implementaçàn, seriam necessários 3 (três) novas threadr: uma produtora, uma consumidora e uma flimad de exibiçầo, além da realizaçăo de cálculos de tempo de envio de pacotes do servidor para cute a nova arquitctura pudesse realizar o armazenamento em buffer; de modo eficiente.

\subsection{2 - Compressão e Descompressão de Video}

()s tempos de descompressào, obtidos na descompactação dos quadros com os codificadores IPEC. se mostraram lincares, mas muito aquém do ideal para transmissão de vídco com taxas de exibiçio) de quadros superiores a 25 quadros por segundo (taxa mínima para transmissòes com qualidade de vídeo para ' 1 'V, por excmplo). Para a taxa de 25 quadros por segundo, o tempo para descrnnpactaçio teria de ser de 40 milissegundos por quadro, e para a compactação JPLG apenas quadros com tamanho máximo de 19 Kbytes, o que implica a resoluçào de aproximadamente 81 x 81 pi $\%$ r. Se taxas mais baixas de exibiçào fossem requeridas, como 15 quadros por segundo, o tempr de descompactaçào seria de 66 milissegundos, o que acarretaria cm resoluçào de 106 x 106 pìe/s: Como soluçào, aconselha-se a utilizaçào de codificadores mais cficientes na linguagem Java w a implementaçào em linguagens cm que o tempo de processamento seja inferior.

No caso da compactação com transformadas mavelets e codificação LZW, obteve-se tempos muito superiores ao da compactaçào JPEG. Analisando apenas o tempo das transformadas, obscrvouse uma evoluçào lincar, enquanto o comportamento do tempo da transformada apresentou-se 
nâo-linear, crescendo de modo a comprometcr muito o desempenho da compactaçào. Para obtcr melhores resultados, algumas alternativas podem ser rclatadas:

- Escolha de uma nova transformada: a cscolha da Daub4 foi feita em virtude da facilidade de implementação, mas um estudo minucioso pode ser feito buscando transformadas navelets mais rápidas, mas que também apresentem tempo de cxecução linear cm relaçào ao tamanho do arquivo sendo processado;

- Novo método de codificação: $\Lambda$ codificação LZW é um algoritmo que obtém ótimos resultados em termos de compressão; contudo, sua implementaçào se mostrou complexa, c seu tempo de exccuçào, comprometedor. Um método de codificaçào com exccuçào mais rápida (mesmo com ganhos menores) c com evoluçào linear é requerido;

- Novo modelo de cores: O modelo de decomposiçào das matrizes de uma imagem em Java é o padrào RGB, e este modelo foi utilizado para processamento de imagens coloridas utilizando a transformada Daub4. $\Lambda$ ssim, para cada imagem colorida, três matrizes foram processadas. Se o modelo YUV, que decompòc uma imagem colorida em duas matrizes (de crominância e luminância), fosse utilizado, o processamento de uma imagem colorida teria um ganho considerável. Além disso, com o modelo YUV seria possivel analisar o espectro de freqüências cm que o olho humano nào é sensívcl c realizar a quantizaçào das matrizes, aumentando o grau de compressào sem perda scnsível (1) olho humano.

\section{2 - Contribuições em Trabalhos do Grupo InterMídia}

\subsection{1 - Transmissão de Vídeo Usando IPv6 e Multicasting em Redes de Alto Desempenho (Martins, 2000)}

Liste trabalho teve como objetivo a configuraçào de uma infra-cstrutura de rede que suporte minlticusting de pacotes e o protocolo IPv6. Para a realizaçào de medidas de performance da rede, uma iplicaçăo clicnte/scrvidor foi avaliada, e a comunicaçăo por sockés IPv4/1Pv6 dessa aplicacio foi desenvolvida em conjunto com o pesquisador Juciano Martins. Detalhes desta implementaçào foram mostrados no capítulo 5, no tópico 5.4-A Aplicação Cliente/Servidor 
com Suporte IPv4/IPv6. O thread gerador de quadros e os cálculos e implementaçào para cmissăo de pacotes pelo servidor foram algumas das contribuiçòes para esse trabalho.

\subsection{2 - Arquiteturas para Compressão de Vídeo Baseado em Sistemas Reconfiguráveis (Soto, 2000)}

Liste irabalho consistiu da avaliaçào de arquitetura e técricas de compressào de imagens voltadas ì implementaçà em sistemas reconfiguráveis ( $\left.P^{P} G, A\right)$. A contribuiçào para esse trabalho foi reterente ao processo de compactação de imagens utilizando transformadas mavelets, cm especial a transformada Daubechies 4 , sendo algumas implementaçòes de transformadas waveletr em Java realizadas pelo autor do presente trabalho. Detalhes das implementaçòcs feitas com este tipo de transformada foram mostrados no capítulo 5, no tópico 5.5-Compactação de Vídeo.

\subsection{3 - Projeto de Sistema de Sincronização de Streams de Vídeo para Serviço Multicast (Silva, 2000)}

Este trabalho propôs uma modelagem em UML (Unified Modelling Language) de um sistema de transtnussão de video sincronizado usando multiasting. Além da técnica de multicasting, uma das lecroleggias estudadas em conjunto para uma futura implementaçào foi a $\Lambda$ PI JMP, que postertormente foi utilizada no presente trabalho.

\subsection{4 - Sobre a Implementação e Avaliação de Técnicas de Codificação e Distribuição de Video Baseadas em Conteúdo (Goulart, 2000)}

Nesse irabalho em andamento, cstudos exploratórios na área de integraçào e interaçào de mídias têm sido cfetuados, com ĉnfase em padròes de compactaçào. $\Lambda$ contribuiçào para cste trabalho for o scrvidor de video implementado, que poderá servir como base para uma futura versão na yual scja possível realixar a transmissào de streams MPEG-4. 


\section{Referências}

(Bicrenger, 20)(0)

(Bradier, 1996)

(Comer, 1995)

(Cornell \& Horstman, 1997)

(Crawford, 1996)

(1)aubchics, 1992)

(1)ering, 1995)

(1.1lio1, 1982)

(Irikson, 1994)

(1) entice, 2000$)$

$(1$ lanagan, 2000)
Bierenger, P. Linux: IPv6, disponivel $\mathrm{cm}$ http://www.bieringerde/linux/1Pv6/, 11 de novembro de 2000

Bradner, S.O \& Mankin, A., IPng, Internet Protocol Next Generation, Addison-Wesley Ipng Series, 1996.

Comer, D. IE. Internetworking Whit 'I'CP/IP. Vol. 1, PrenticeHall, 1995.

Corncll, G. e Horstmann, C.S.: CORE JAVA - Guia Autorizado da SUN Microsystems, São Paulo, Makron Books, 1997.

Crawford, M. A Method for the Transmission of IPv6 Packets over Lthernet Networks, RFC 1972, agosto de 1996, disponivel cm http://www.grapheomp.com/info/ $\mathrm{rfc} / \mathrm{rfc1} 972$.html, 12 de novembro de 2000.

Daubechies, I. Wavclets, Philadelphia: S.I.A.M.

Deering, S.; Hinden, R, Internet Protocol, Version 6 Specification. Rl:C 1883, 1995.

lilliotr, D.I: c Rao, K.R. Last Transforms: Algorithms, Analyses, Applications (New York: Academic Press), 1982.

Erikson, II. MBONE; The Multicast Backbone, Communications of the ACM, Vol. 37 \#, ago. 1994, pp. 54 60 .

Fenner, B., Handley, M., Holbrook, H. et al., Protocol Independent Multicast - Sparse Mode (PIM-SM): Protocol Spccification (Revised), Internet Draft, 24 de novembro de 2000, disponivel em http://www.ietf.org/internetdrafts/draft-ictf-pim-sm-v2-ncw-01.txt

Hanagan, M. JIPSY:IPvG for Java, disponivel em http://www.progsoc.uts.edu.au/ mpf/JIPSY/,11 de novembro de 200() . 
(Fluckiger, 1995)

(Iturhut, 1995)

(Goularte, 2000)

(Nelson, 1991)

(IIT) RFC, 1999)

(IS(), 1997)

(Jamsa ct al., 1997)

(Johnson, 1997a)

(Jonhson, 1997b)

Kosicur, 2000)

(1.oshin, 1999)

(Martms, 2001)
Iluckiger, Li. Understanding Networked Multimedia Applications and Technology. Hemel Hempstead - UK, Prentice-I Iall, 1995.

Furht, B. A Survey of Multimedia Compression 'l'echniques and Standards - Part I : JPEG Standard. Real-Time Imaging, vol. 1, n. 1, pp. 49-67, 1995.

Goularte, R., Sobre a Implementação e Avaliação de T’ćcnicas de Distribuição de Video Interativo Baseadas em Conteúdo, proposta de projeto de doutorado, 2000 , ICMC-USI?

Nelson, M. The Data Compression Book (Redwood City, CA: M\&T Books), 1991.

IEFT RFC 1889, RTP: A T'ransport Protocol for Real Time Applications. Versào atual: http://www.ietf.org.internetdrafts/draft-ictf-avt-rtp-new-04.txt.

ISO/IFC IS 13818, MPEG-2: Generic coding of moving pictures and audio information, 1997.

Jamsa, K.: et al. JAVA: A Biblioteca do Programador. São Paulo, Makron Books, 1997.

Johnson, V., Johhson, M. I Iow IP Multicast Works A technical overview of IP Multicast concepts, addressing, group management and approaches to routing, outubro de 1997, disponivel cm http://www.ipmulticast.com/ community/whitepapers/howipmcworks.html

Johnson, V., Johnson, M., Introduction to IP Multicast Routing - A technical nverview of IP Multicast routing protocols and their features, outubro de 1997, disponivel em http://www.ipmulticast.com/ community/ whitepapers/ introrouting.html.

Kosicur, D. Network Stratergy Overview - IP Multicasting, disponivel em http://www.cisco.com/warp/public/cc/ techno/protocol/ipmu/tech/ipmc_wp.htm, 23 de novembro de 2000

Loshin, P, IPv6 - Clearly Lxplained, Morgan Kaufmann, 1999.

Martins, L. 'l'ransmissào de Vídeo U'sando $1 P^{3} v 6$ e Multicasting. em Redes de Nto Desempenho. Dissertaçào de Mestrado, ICMC-USP, 2001. 
(MSR, 2000)

(Press, 1992)

(Rlic, 1999)

(Silva, 2000)

$(S o t 0,2000)$

(Steinmet7, 1995)

(Stev'ns, 1998)

(Sun, 1999)

(lancmbaum, 1996a)

(Tancmbaum, 1996b)

(Thakrar, 1996)

(Thomas et al., 1997)

(Wallace, 1991)
Microsoft Research IPvG, Internet Protocol Version 6, disponivel em http:// www.research.microsoft.com/ msr[Pv6/,11 de novembro de 2000.

Press, W. H.; Flannery B. P.; Teukolsky, S. A.; Vetterling, W. I. Numerical Recipes in C. - The Art of Scientific Computing. Cambridge Univerty Press, Cambridge, 1992

Hinden, R., Deering, S. ct al., IP Version 6 Addressing Architecture, RlC 2373, disponivel $\mathrm{cm}$ http://www.ietf.rup.br/ftp/rfc/ rfc2373.txt, 16 de dezembro de 1999 .

Silva, D,C., Projeto de Sistema de Sincronização de Streams de Vídco para Serviço Multicast, São Carlos: ICMC - USP, 2000. Dissertação de Mestrado.

Soto, W. L. Arquitcturas para Compressào de Vidco Baseado $\mathrm{cm}$ Sistemas Reconfiguráveis. T'ese de Doutorado, ICMC-USP, 2000 .

Steinmetz, R; Nahrstedt, K. Multimedia: Computing, Communications and Applications, Englewood Cliffs, NJ: Prentice Hall, 1995.

Stevens, W, Unix Network Programming - Networking APIs: Sockets and XII, vol 1, Segunda Ediçào, Prentice Hall, 1998

Sun Microsystems, Inc. Java Media liramcwork API Guide. 1998-1999 Sun Microsystems Inc.

T'ancmbaum, A.S. Computer Networks, Prentice-Hall, 3 a ediçào, 1996.

Tanembaum, A.S.: Distributed Operating Systems, Prentice I. Iall, 1996)

Thakrar, K. \& Andleigh, P.K. Multimedia Systems Design, Prentice-Hall, Ncw Jersey, 1996.

Thomas, M.D. et al:: Programando em JAVA para a Internet. Sào Paulo, Makron Books, 1997.

Wallace, G.K. The JPEG Still Picture Compression Standard, Communications of the ACM, v. 34, n. 4, p. 30-44, Abril de1991, disponivel $\mathrm{cm}$ ftp://ftp.uu.net/graphics/ jpeg/wallace.ps.gæ, 20 de novembro de 2000. 
(Welch, 1984)

(/iv (4 al, 1978)
Welch, '1', A 'Technique for High-Performance Data Compression, Computcr, June 1984.

Ziv, J., and Lempel, $\Lambda$. IEEF. Transactions on Information Theory ( $\Lambda$ Universal Algorithm for Sequential Data Compression), vol. I'l-24, pp. 530-536, 1978. 


\section{Apêndice - Glossário de Siglas}

\begin{tabular}{|c|c|}
\hline API & Application Programming Interface \\
\hline ARGB & Alpha, Red, Green, Blue \\
\hline ARP & Address Resolution Protocnl \\
\hline AW'T & Alstract II indon Toolkit \\
\hline BUS & Braddast Linkinamin Server. \\
\hline DAUB4 & Dawbecliaes 4 \\
\hline DC & Depuitamento de Computución \\
\hline DCT & Discret Cassin Transform \\
\hline DVMRP & Distance I éctor Multicast Routing Protocol \\
\hline DW'T & Discret W'avelet Transform \\
\hline FDDI & Fiber Distributed Data Interface \\
\hline FFT & Fiast Fourrer Transform \\
\hline FPGA & Field Programmable Gatemay Array \\
\hline FPS & Frames per Second \\
\hline Gbps & Gigabit por segundo \\
\hline GUI & Grapbic User't Interface \\
\hline HDTV & High Defintition TT \\
\hline ICMC & Instituto de Cièncias Matemationas e de Computacaio \\
\hline IEEE & Instimute of I:lectrical and ISlectronics Ingineers \\
\hline IETF & Internet lingineering Task Iorre \\
\hline IGMP & Internet Group A Lanugement Protocol \\
\hline IOS & Internetnorking Operating Syateme \\
\hline
\end{tabular}




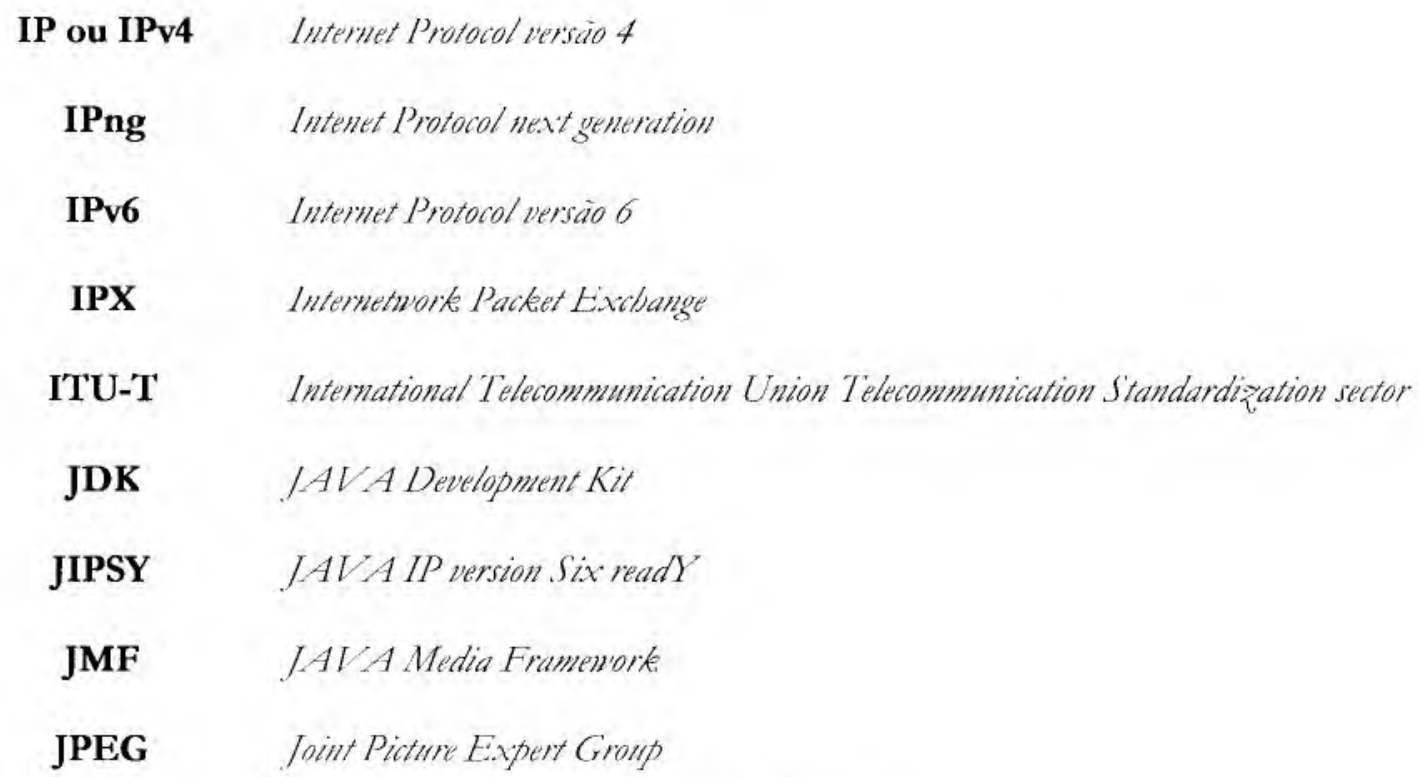

